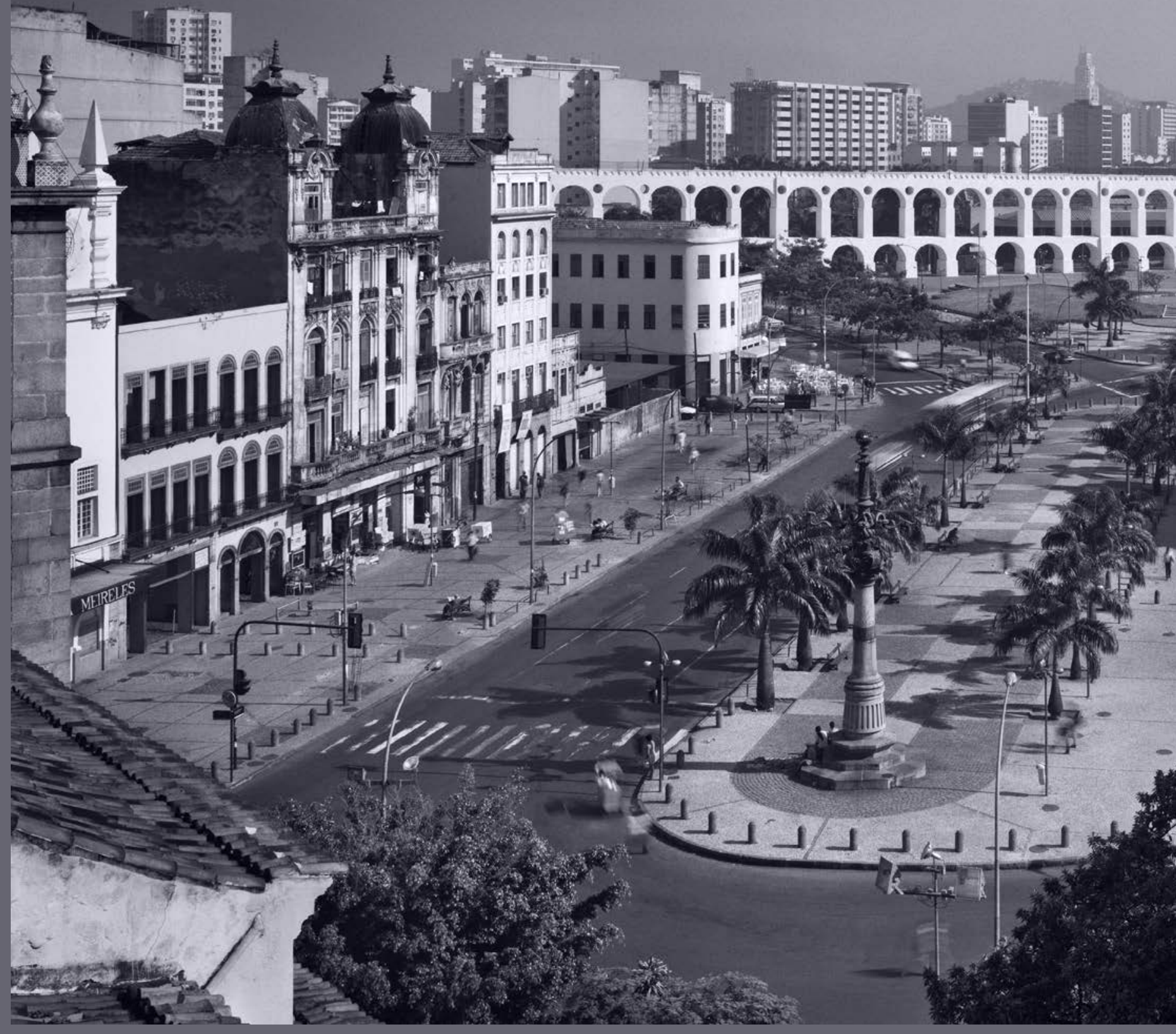




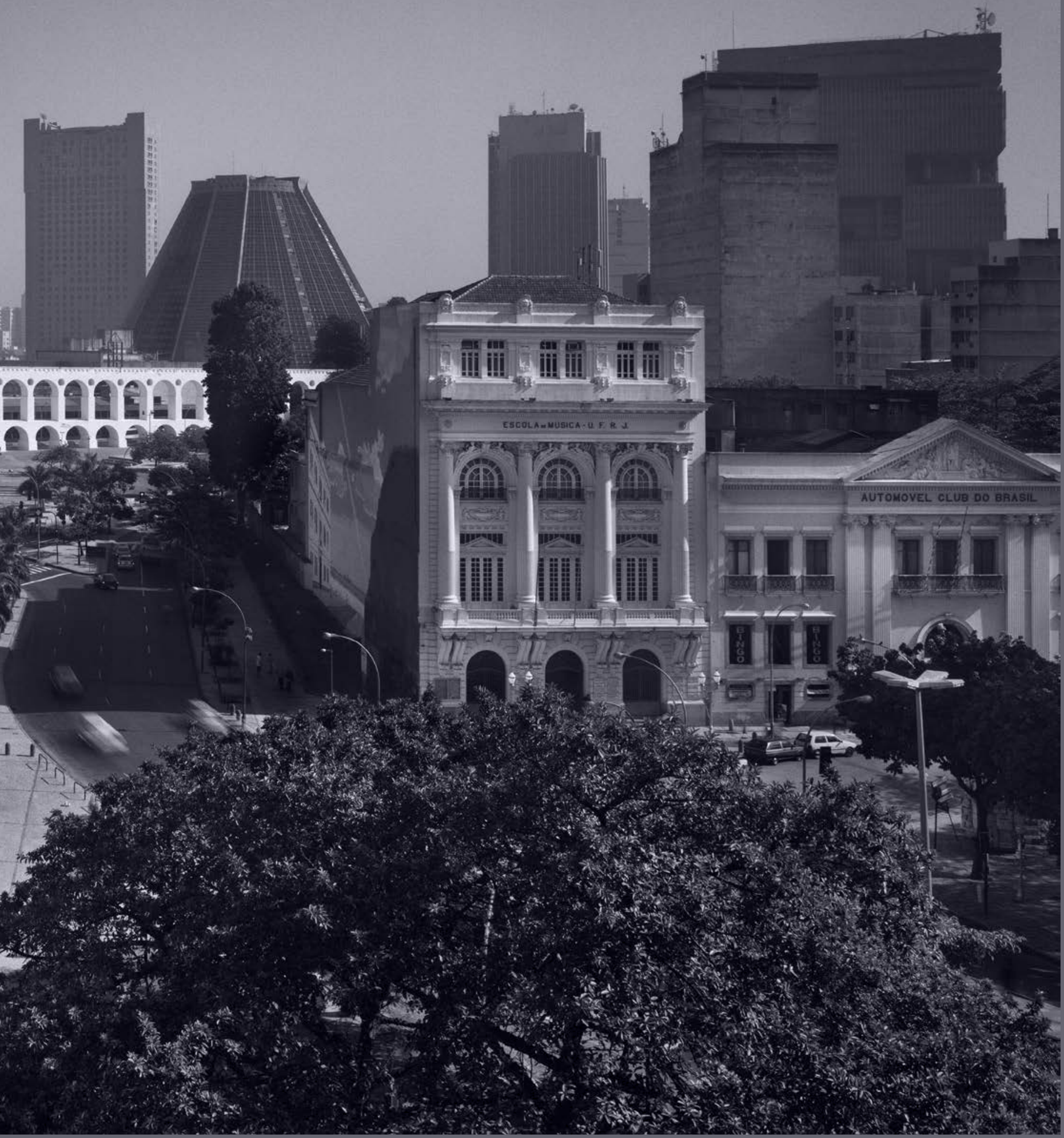

\section{a esdi e o ensino formal de design}


A ESDI, Escola Superior de Desenho Industrial, foi a instituição na qual Bergmiller desenvolveu suas atividades didáticas. Juntamente com Alexandre Wollner foi o responsável pela definição dos critérios do que seria o ensino de um design paramétrico no Brasil, com todas as suas possibilidades e limitações reais. Uma das características do design paramétrico, segundo Charles Jencks, seria, além da simplicidade formal quase reticente e de detalhamentos muito diretos e friamente resolvidos, a ausência de metáforas visuais e a preferência pelas conotações de precisão e neutralidade. Foi definido um plano didático, selecionado um grupo de professores, estabelecida uma forma específica de vestibular, foram instaladas oficinas e escolhidos seus mestres, trabalhos que, até então, nunca haviam sido realizados no ensino superior brasileiro. Isso era coerente com o contexto político da época, pois nunca antes um representante do poder executivo havia assumido uma posição tão voluntarista como o governador Carlos Lacerda, do recém-criado Estado da Guanabara, em relação a experiências inovadoras no ensino superior. A leitura do discurso de Lacerda por ocasião da assinatura do decreto de criação da ESDI, em 5 de dezembro de 1962, evidencia algumas ideias marcantes. Uma das justificativas principais para a criação da Escola e outras iniciativas semelhantes é a necessidade de criar quadros, "a principal crise brasileira", pensamento que, como já vimos, poderia ser encontrado, em Roberto Simonsen, para justificar exatamente a fundação de outra instituição inovadora de ensino superior em São Paulo, a Escola Livre de Sociologia e Política em 1933.

No discurso de inauguração da Escola, Roberto Simonsen disse:

- A crise que se alastra pelo mundo afora está provando, pela sua duração e pelos seus efeitos, que não é um simples fenômeno subordinado ao ciclo periódico de depressóes econômicas. Aos historiadores do futuro não se deparará que essa crise, a guerra de 1914, o surto do comunismo na Rússia, a implantação do fascismo na Itália, o enriquecimento rápido e exagerado norte-americano engorgitado no craque de 1929, as revoluçóes na América do Sul e na Ásia sejam fatos demonstrativos do crescimento desarmonioso de uma grande civilização? Desarmonioso porque não soube justapor às conquistas inigualáveis obtidas no campo da ciência uma estrutura econômico-política baseada no estudo profundo do organismo social, dotada de sentimentos espirituais e morais em perfeita harmonia com o desenvolvimento da técnica. Não se terá desenvolvido o aspecto material em desproporção com outros fatores essenciais e se criado uma civilização sem alma? Durante o curso dessa civilização conseguiu-se um relativo estado de equilibrio para a maioria dos povos $e$ um aumento considerável do seu bem-estar pelos progressos da ciência. A discordância, porém, da evolução econômica, em face da evolução política e social e o esquecimento do princípio da unidade do mundo, decorrente da interdependência sempre crescente entre os povos, conduziram-nos ao estado atual em que assistimos, no dizer de Wells, a "um páreo desabalado entre o esforço para um reajustamento, a revolução social e o espirito da desordem". Esses fenômenos são tanto mais agudos e notáveis quanto maior o grau de civilização a que tenham atingido as naçóes.

No caso brasileiro, estamos relativamente em posição excepcional. A pobreza do país e circunstâncias familiares aos que pensam em nossos problemas impediram o nosso crescimento exagerado nesse rumo da civilizaçâo. Dai a crise estar sendo mais atenuada entre nós; crescemos menos, erramos menos. No entanto, para os que sabem observar, o mundo oferece neste instante uma extraordinária demonstração experimental para os estudos sociais, políticos e econômicos. A revolução brasileira veio provar como é minguado o nosso contingente de homens de Estado e salientar a profunda ignorância em que vivemos da nossa verdadeira situação social. Ora, uma escola como a que aqui imaginamos, visa a promover e sistematizar, no Brasil, o estudo da sociologia nacional, em harmonia com pesquisas orientadoras das instituiçóes politicas, jurídicas e econômicas mais adequadas ao nosso meio e nossa raça. A ação dos técnicos especializados, saídos de nossas escolas, já é hoje insuficiente, se não for inspirada por uma orientaçáo segura e zeladora de uma sadia evolução social. Como consequência mesma do grande progresso técnico que o mundo atingiu, da rapidez das comunicaçôes e transmissóes do pensamento, da difusão do ensino, tudo está evoluindo rapidamente - a sociologia, a ciência econômica e até a ciência do direito. O centro que nos propomos construir é, em tais condiçöes, uma instituição indispensável ao meio a ao momento que vivemos. ${ }^{1}$

Simonsen dizia ainda que tais quadros tornavam-se essenciais às tarefas de levantamento e classificação de dados que permitissem o exercício de qualquer tipo de planejamento no país. A ausência desses dados era por ele conside- 
rada dramática e crucial para que se estabelecesse no Brasil um encaminhamento democrático. Lacerda secunda-o, ao apontar a ausência de quadros como uma espécie de mãe de todas as crises:

A principal crise brasileira, aquela que sobretudo dificulta a solução das outras, é a falta de quadros no país. A produção de homens capazes, o volume, se assim posso dizer, de homens em condiçôes de influir na solução dos problemas, bastava a esse país, quando ele era grande apenas na extensão territorial, mas não o era nem mesmo no vulto de sua população, e muito menos no número de pessoas em condiçôes de consumir o que as suas elites podiam gerar, em arte, em riqueza, em técnica para problemas então relativamente simples.

Foi o tempo em que o Brasil tinha poucos engenheiros, mas a rigor não carecia de tê-los muitos. Tinha poucos músicos, poucos poetas, poucos marceneiros, poucos ferreiros, poucos jurisconsultos, poucos bastavam enfim para o que então eram as necessidades de consumo do povo brasileiro. Hoje, felizmente, aumentou não somente a população, mas aumentou a sua exigência de civilização. No entanto, a crise da Universidade, a crise da responsabilidade, a crise de uma autoridade verdadeiramente livre, consciente e capaz, fez com que empobrecesse enormemente a vida brasileira, e temos diante de nós o grave problema de formar uma democracia sem formar as elites populares, capazes realmente de dar-lhes significação, conteúdo e progresso autêntico. ${ }^{2}$

Parece fazer parte do ideário das elites brasileiras o conceito de crise, e a questão de que formas modernas de trabalho e de conhecimento devam ser antecedidas pela adequada formação de pessoal competente para sua articulação. Em primeira análise, essa observação procede e se justifica. No entanto, leituras mais atentas dos textos de Roberto Simonsen e de Carlos Lacerda, entre outros intelectuais orgânicos de certa burguesia brasileira, indicarão também um claro receio de que tais formas de ordenamento social e produtivo possam ser interpretadas por outro tipo de intelectual não proveniente de um saber formal estabelecido e regulamentado, mas que seja avalizado exatamente pela tão temida crise. Tanto Simonsen como Lacerda são políticos de seu tempo, portadores de ideias conservadoras, porém absolutamente cientes de que ideias inovadoras não representavam nenhum problema para as elites, desde que fossem seus elementos os responsáveis por sua introdução na sociedade. Portanto, a ideia de formação de quadros, presente tanto nos discursos de um como de outro, representa, na verdade, a justificativa para que a sempre atenta elite brasileira trate de modernizar-se rapidamente para manter, como sempre, o controle de qualquer processo de desenvolvimento possível. Tanto Simonsen como Lacerda têm a sutil percepção de que as instâncias acadêmicas tradicionais não respondem mais às demandas de uma formação de quadros mais atualizados, aptos a lidar com as ideias mais avançadas do planejamento industrial, em um caso, e de projetos de produtos industriais, no outro.

Sempre se imaginou haver alguma diferença significativa entre Juscelino Kubitschek e Carlos Lacerda. ${ }^{3}$ As lendas políticas assim o quiseram. Porém, no caso específico das ideias sobre design, há uma curiosa coincidência em seus discursos. Juscelino afirmara, em entrevista a Jayme Maurício ${ }^{4}$ no Correio da Manhã, de 30 de janeiro de 1958:

- O Brasil forma um arquipélago que precisa disciplinar o seu progresso desordenado, transformá-lo num continente unido, interligado, sem os desniveis de riqueza, injustos e remediáveis que um dia poderão ameaçar a própria unidade nacional. Brasilia impóe-se deste modo como um fulcro econômico e cultural, em torno do qual deve girar, disciplinadamente, o processo de desenvolvimento. Brasilia não é nenhuma utopia, mas uma cidade construida para a transferência da capital do pais agora, ou seja, como ele é. Como todos sabem, somos ainda um país subdesenvolvido e socialmente desajustado. Se o simples planejamento urbanistico decorrente da transferência da capital fosse solução, não haveria problema social no país. A transferência visa precisamente a acelerar o processo democrático de integração econômica e social. Alguns dias antes, por ocasião da inauguração do Museu de Arte Moderna do Rio de Janeiro MAM/RJ, em 21 de janeiro de 1958, o presidente da República, que era também integrante do conselho deliberativo do museu em inauguração, afirmou sobre as intenções de ali se estruturar um curso voltado para o design:

- Uma civilização tecnoindustrial que não crescesse vinculada a uma intensa atividade artística estaria ameaçada de deformar-se. O impacto da industrialização sobre as atividades artesanais de conteúdo artístico só pode ser compensado por um cultivo dos valores estéticos capazes de educar a máo do tecnólogo e do operário, preservando características de singularidade e beleza que de outro modo se perderiam. ${ }^{5}$ 
A criação de escolas superiores livres é uma prática frequente em países onde a tradição acadêmica impede eventualmente uma modernização das ideias pedagógicas. É curioso como, o peso dessa tradição parece ser tanto maior quanto menos rico e menos democrático é o país. As reformas são sempre realizadas por setores específicos e limitados da elite. No plano geral, o conjunto dessa elite, em geral, termina absorvendo as experiências e as propostas de caráter experimental, tirando seu caráter inovador, procurando, depois de algum tempo, discipliná-la e enquadrá-la formalmente em alguma instituição mais conservadora. A quem se arriscou e se expôs numa alternativa experimental resta ser avaliado em um contexto que, a princípio, foi considerado anacrônico, mas que reage de forma intensa ao elemento de inovação e termina por reduzi-lo apenas a alguns detaIhes que servem para coonestar e manter essa estrutura superada. Juscelino Kubitschek notabilizou-se mais por criar estruturas administrativas livres do que escolas superiores, mas seu sentido não deixa de ser muito semelhante. Seus diversos Grupos Executivos, ${ }^{6}$ dirigidos a objetivos específicos, possibilitaram notáveis mudanças tanto nas estruturas administrativas como até em setores da produção privada no Brasil. A diferença é que no caso dessas mudanças em setores administrativos e produtivos a validade dos Grupos Executivos poderia ser revogada à medida que seus objetivos práticos e materiais tivessem sido atingidos. No caso de escolas como isso poderia ser medido? Em que exato momento poder-se-ia dizer que um objetivo havia sido alcançado, e que objetivo seria esse? Não é difícil estabelecer quando se cumpre um projeto, mas é impossível definir quando terminará um processo. Ao contrário dos Grupos Executivos, que poderiam ser considerados projetos ou elementos de um projeto, escolas livres quiseram transformarse também em processos.

A ESDI foi criada aproximadamente dez anos depois do início das atividades da HfG-Ulm, em 1952. Na verdade, constatar a ausência de quadros para uma atividade como o design representa uma demonstração de algum progresso em relação à demanda da Escola Livre de Sociologia e Política em 1933. As circunstâncias dessa iniciativa são bastante conhecidas hoje, ainda que persistam lendas e narrativas sobre um fato que pode ser interpretado como um fenômeno político, a par de uma iniciativa pedagógica. A criação da Escola fez parte de um conjunto de projetos coerentes com a visão otimista das décadas de 1950-60 no Brasil. Bergmiller aponta como um dado diferente a Escola ter resultado de uma ini- ciativa do Estado e não particular, numa época em que as ideias de vanguarda eram mais comuns entre a burguesia do que nos governos, principalmente nas esferas estaduais ou municipais. De qualquer forma, deve-se sempre lembrar que é nessa época que o Rio de Janeiro passa por uma reformulação urbana bastante radical, com a implantação do projeto do Parque do Flamengo, ${ }^{7}$ a construção da adutora do Guandu e do túnel Rebouças - todas obras urbanas exemplares. Com um mínimo de atenção, pode-se verificar que, nessas e em outras obras e iniciativas, havia a presença da personalidade forte do governador Carlos Lacerda, um político controvertido, mas de rara inteligência. Havia também algumas coincidências que em nada dependeram de acasos. Muitas das pessoas estavam envolvidas com os projetos do MAM/RJ, do Parque do Flamengo e da própria ESDI e, independentemente de seus posicionamentos políticos, por vezes conflitantes, essa presença indicava a existência de uma elite orgânica e pensante no Estado da Guanabara, que conseguiu estabelecer alguns projetos e cumpri-los.

É o elemento político, a decisão do governador que explica, em parte, porque a primeira escola de design brasileira foi criada no Rio de Janeiro e não em São Paulo, principal centro de industrialização do país. Outras justificativas poderiam ser lembradas. Era no Rio, antiga capital do Império e da República, que ainda se concentrava grande parte da vida cultural do país. Além disso, pode-se lembrar também um interessante argumento de Júlio Katinsky, ${ }^{8}$ arquiteto, historiador e professor da Faculdade de Arquitetura e Urbanismo da Universidade de São Paulo, que cita a existência de um movimento acadêmico no Rio, centralizado na Escola Nacional de Belas-Artes, herdeira da antiga Escola Imperial de BelasArtes, que tornaria propício o surgimento de pensamentos de vanguarda na cidade como reação ao academismo, fato que não ocorreu em São Paulo. ${ }^{9}$ Mas, certamente, o principal influxo para o a criação da ESDI foi a existência de um grupo de pessoas interessadas na renovação urbana da cidade, na preservação de sua importância cultural depois da mudança da capital, e na estruturação de um museu relativamente novo e diferente, dentro de padrões internacionalistas, bem ao gosto de uma burguesia local, um pouco diferente da que existia em São Paulo, mas com ideias semelhantes. Esse grupo sempre esteve, de um modo ou de outro, presente na criação da Escola. Por outro lado, existe a inequívoca ambição do governador em se demonstrar um político moderno, realizador e inovador. Situado circunstancialmente à direita no plano político nacional, Carlos Lacerda precisava dar de- 
monstrações concretas de sua capacidade empreendedora em todos os níveis administrativos, e a criação de algo novo no ensino superior era um fato que certamente causaria inveja a qualquer político da época.

A ESDI surgiu assim favorecida pelo poder público estadual, porém, com um projeto que em pouco tempo a conduziria a tornar-se também um problema para esse poder. A descontinuidade administrativa não parece mais ser um desmando político nacional. Parece até mesmo constituir-se em seu elemento vital e, novamente, podemos pensar que, em um país cuja primeira estrutura administrativa foram capitanias hereditárias não seria estranho que cada governo ao se estabelecer se considerasse dono e árbitro de todas as prerrogativas e instâncias do poder. A exemplo do que Renato De Fusco diz sobre a Itália, uma cultura pública, um sentido republicano real, nunca foi implantado no país.

Várias pessoas participaram dos trabalhos preliminares de estruturação da ESDI. A comissão que ficou encarregada da formulação final do primeiro plano da Escola compunha-se de Maurício Roberto, ${ }^{10}$ Flávio de Aquino, ${ }^{11}$ Simeão Leal, ${ }^{12}$ Aloísio Magalhães, Alexandre Wollner e Karl Heinz Bergmiller. Os princípios básicos estabelecidos foram que uma escola de design deveria ter um programa prioritariamente criativo e inovador, sempre sujeito a questionamentos e renovações. Até mesmo os bons resultados deveriam ser constantemente revistos e não poderiam se constituir em modelos ou padrões para meras repetições. Deveria haver uma especial atenção na seleção dos alunos, pois se considerava que a qualidade de um curso pouco ortodoxo, como se pretendia, dependeria em grande parte do corpo discente. Entrevistas e testes vocacionais foram incluídos no vestibular como uma forma de seleção mais direta, mais próxima ao pensamento dos professores diretamente ligados à estruturação da Escola.

Os problemas de seleção estavam presentes também na escolha do corpo de professores que deveria ser muito precisa e rigorosa. Existiam poucos designers atuantes na época, no Rio de Janeiro e mesmo no país e, além disso, havia a necessidade de contratar professores para as áreas teóricas e de apoio ao desenvolvimento do projeto. Para a comissão, segundo Bergmiller, desde o início ficou claro que não seria fácil estabelecer uma relação produtiva e criativa entre a área de projeto e as demais disciplinas, principalmente porque a maioria dos professores dessas áreas estava acostumada a procedimentos mais tradicionais, acadêmicos, em alguns casos até mesmo burocráticos. A comissão consi- derou que um trabalho mais coletivo, que evitasse o isolamento de qualquer professor, seria um caminho para superar esse problema, evitando a dispersão do ensino. 0 sistema de avaliação dos alunos foi inicialmente planejado para se constituir numa ação coletiva, da qual participariam todos os professores. Dessa forma, os professores deveriam dedicarse a uma permanente troca de ideias, definir temas de projetos em conjunto e avaliar o rendimento do curso também de forma coletiva. Nesse processo, seria possível não apenas avaliar os alunos como também avaliar cada disciplina e cada professor. Um objetivo também foi estabelecido como essencial: dever-se-ia formar um novo tipo de profissional, alguém que tivesse uma atitude de designer e que jamais se limitasse à busca de um simples diploma de nível superior.

Os professores de projeto selecionados foram, em sua maior parte, profissionais atuantes. Considerava-se essencial que eles tivessem experiência de mercado e de projeto para formar uma nova geração de profissionais, designers que saberiam detectar um problema na sociedade, enfrentar suas circunstâncias e propor soluções econômica e socialmente viáveis. A comissão nunca pensou a ESDI como uma escola técnica e profissionalizante. Imaginou os futuros profissionais como pessoas com conhecimentos técnicos, sociais e de projeto, capazes de entender a complexidade de sua atuação, trabalhar em equipe, junto com outros designers e especialistas de outras áreas, eventualmente coordenando essas equipes interdisciplinares. Saber desenhar, fazer modelos e dominar relativamente bem algumas questões formais não seria suficiente para se tornar um designer. Na verdade, buscava-se a formação de uma elite capaz de justificar tanto empenho num projeto novo no país. Imaginava-se formar pessoas com um alto nível de conhecimento, capazes de chegar com segurança a uma solução de projeto e, também, capazes de argumentar e defender de forma convincente o próprio trabalho. Para isso o aluno deveria ser constantemente motivado a explicar e justificar seu trabalho e sua própria presença e permanência na Escola. Pode-se dizer que a comissão foi idealista, mas dificilmente pode-se questionar sua coerência. Talvez, ao longo do início do processo, tenha faltado maior consistência ao trabalho. Porém, esse não era mais um problema da comissão e, se houve alguma precariedade de um sentido coletivo de trabalho que, dadas as circunstâncias da realidade sempre foi difícil, é inegável o esforço desenvolvido em especial pelos oriundos de UIm, para que isso não ocorresse. 
Existiu o precedente dos planos da Escola Técnica de Criação do Museu de Arte Moderna do Rio de Janeiro, elaborados desde o início da proposta dessa instituição e reestruturados por Otl Aicher e Tomás Maldonado, quando realizaram cursos específicos sobre design no MAM/RJ. Em duas visitas de Maldonado ao Brasil e à ESDI, em 1993 e 2004, foi ainda possível esclarecer a importância dessas ideias elaboradas inicialmente para o MAM/RJ e para o projeto da ESDI. Nessas ocasiões, verificamos o quanto é possível incorrer em equívocos ao construirmos uma história baseada em mitologias veiculadas pela mídia e até mesmo por documentações oficiais. Os planos originais do MAM/RJ serviram para a posterior criação da ESDI; não houve, porém, um processo linear de assimilação, mas um trabalho de adaptação bastante complexo, até mesmo pelo fato de a iniciativa de criar a ESDI partir do poder público, e estar sujeita a determinações bastante diversas das que poderiam incidir sobre uma escola privada, sem caráter oficial, sem preocupações maiores com reconhecimentos e outras imposições oficiais.

Nesse processo de assimilação, Bergmiller considera que teve participação decisiva em várias ocasiões. A primeira delas, desenvolvida junto com Alexandre Wollner, foi essencialmente uma contra-argumentação crítica de dois designers formados em Ulm em relação às influências americanas trazidas através de Joseph Carrero, ${ }^{13}$ um designer de menor expressão que veio ao Brasil substituindo Jay Doblin, ${ }_{1}^{14}$ proposto a princípio como consultor pedagógico. Havia alguma insegurança no grupo encarregado da estruturação da ESDI, e a ideia de se trazer Jay Doblin era uma forma de se examinar outro tipo de formulação didática. Mas, por motivos não muito claros, Doblin não veio ao Brasil e, em seu lugar, veio Joseph Carrero com propostas "francamente retrógradas", segundo Bergmiller; com elementos bastante claros de ativismo e intuicionismo, heranças da Bauhaus em alguns aspectos, e derivações tipicamente norte-americanas de sua ideologia em outros.

É importante diferenciar a crítica ao intuicionismo na conceituação de Bergmiller de uma eventual desvalorização da intuição. Não se trata disso, pois sempre que se manifestou sobre questões como forma, intuição, talento e outras tantas, suas formulações foram simples: seriam elementos essenciais ao design e jamais deveriam ser reprimidos. Ao contrário, era necessário desenvolvê-los. Uma proposta pedagógica válida para o design moderno deveria ser estruturada no sentido da autoconstrução e nessas formulações ficavam claras as influências dos métodos de ensino que, em primeira instância, já estavam presentes até mesmo na reforma da educação de- senvolvida na Alemanha por Kerchensteiner, no final do século XIX, em grande parte das experiências da Bauhaus, na primeira metade do século XX e na Escola de UIm, no processo de reconstrução da Alemanha.

A forma proposta por Bergmiller para se chegar a essa possibilidade seria uma escola permanentemente experimental, aberta às mudanças, portanto sem a definição de limites e circunscrições curriculares. Intuição e talento deveriam ser requisitos para um futuro designer, e a função da escola seria educá-lo para adquirir conhecimento de suas potencialidades e, por que não, das próprias limitações.

Aparentemente, há um conflito em uma proposição que se estrutura de maneira programática e quer, ao mesmo tempo, permanecer mais livre, mais aberta, mais favorável à autoestruturação do indivíduo. Se pensamos em um tipo de ensino dirigido apenas ao indivíduo, talvez esse conflito não seja um problema real. Mas, se pensamos em um ensino que se pretende renovador e reformista, a tese de uma alegada liberdade individual não tem cabimento. A autoformação do indivíduo tornar-se-ia válida desde que fosse justificada por um compromisso reformista e racional. No caso da ESDI, esse conflito, presente já nas dúvidas sobre sua estruturação inicial, reflete duas alternativas quase sempre evidentes nas iniciativas culturais e pedagógicas propostas pela elite ou pelo Estado no Brasil: reforma ou conservadorismo. E quase sempre acaba prevalecendo uma prática conservadora sobre um discurso reformista que, no entanto, é sempre absorvido e apresentado como a base para tal prática.

Mas deve-se procurar entender melhor o que significa valorizar a intuição e não o intuicionismo. Intuição é uma característica humana irreprimível, ao passo que intuicionismo seria uma forma de trabalho assistemática falha, e não falibilista. 0 próprio racionalismo crítico previa a hipótese de se trabalhar necessariamente com a intuição, ao admitir que até a ciência estivesse sujeita a falhas. Merleau-Ponty não faz outra coisa senão admitir a presença e o valor da intuição ao criar o generoso conceito de "verdade falhada". E esse seria o conceito válido de intuição dentro no ideário do design moderno mais consistente. Lembro-me de conversar certa vez com Maldonado a respeito de um assunto paralelo, questões referentes aos conceitos de útil e inútil. Contou-me ele que estando em Veneza, para uma reunião do ICSID, ${ }_{1}^{15}$ no auge da discussão sobre a controvérsia entre um design técnico e frio e um design pessoal e quente, soube que Theodor Adorno ${ }^{16}$ estava na cidade para tratar de outras coisas que não o design. Procurou-o, interessado em saber o que o mestre da 
Escola de Frankfurt pensava sobre o assunto. Discorreu longamente suas ideias, engajadas na época entre os partidários do útil, radicalizando suas posições. Adorno ouviu-o, paciente e atento, até o final das observações. Disse-Ihe que, em princípio, concordava com tudo, porém lhe perguntou: - "Mas, Tomás, você já pensou realmente o mundo sem o inútil?"

Poderia ser possível pensar o design sem a intuição? Poderíamos pensar o homem sem esse atributo? Há sempre a possibilidade da repressão; a história talvez não passe disso, a imposição de repressões e a luta contra elas. Mas, sabemos que certos aspectos são impossíveis de reprimir, entre eles a nossa capacidade de deduzir e também de intuir. A capacidade dedutiva é normalmente aceita como uma característica a ser desenvolvida e o próprio ensino formal sempre teve nisso um de seus objetivos maiores. Talvez por isso mesmo a maioria dos cursos de matemática no ensino primário e médio seja tão ruim.

Aceita-se muito pouco a ideia de que a intuição possa ser também desenvolvida mediante um processo pedagógico. Prefere-se deixar isso ao acaso e então se incorre no intuicionismo, na valorização das potencialidades individuais que, do ponto de vista social, terminam valorizando mais a formação e a informação de cada um do que suas reais capacidades dedutivas e indutivas. Não deixa de ser também uma forma de preservação da própria elite uma vez que os critérios de aferição sobre a capacidade intuitiva são sempre medidos a partir de referências muito particulares e pouco objetivas. Seria, portanto, um absurdo estabelecer um programa de ensino que marginalizasse a capacidade intuitiva de cada aluno. Mas, na lógica de um processo educativo reformista e renovador, e era isso o que se imaginava ao se fazer a ESDI, não seria nada estranha uma prática que visasse a uma crítica radical e contundente contra o uso acrítico dessa capacidade.

A crítica dirigida por Bergmiller e Wollner às influências da escola americana na formação da ESDI teve esse sentido. Mas, convém refletir um pouco sobre a intuição, até mesmo em um sentido mais geral para que as ideias se tornem mais claras. A ideia de intuição liga-se também, no caso particular do design, à discussão sobre o conceito de tempo. Octavio Paz desenvolveu, em 1970, um belíssimo ensaio ${ }^{17}$ sobre o design e suas diferenças do artesanato. Suas afirmações à época provavelmente irritariam profundamente os designers modernos militantes e radicais. Mas, o tempo sempre é o elemento corretivo de nosso pensamento e de nosso entendimento. 0 tempo do artesão seria diferente do tempo do designer visto que um e outro estão submetidos a processos de trabalho e de vida diferentes. Da mesma forma, as questões de uso da intuição estariam sujeitas a tais determinações. Ao artesão seriam concedidas — ou ele mesmo poderia se atribuir dada a natureza de seu trabalho - prerrogativas de tempo que lhe permitiriam um uso mais irrestrito da intuição. Seu trabalho é constantemente criativo e experimental, ao passo que ao designer inserido na indústria tais prerrogativas seriam cerceadas.

Essa compreensão do tempo não seria real para o designer, pois na vida prática, no desenvolvimento de um projeto, que é o que interessa, não se apresentaria viável. Existem clientes, o outro lado, existe a indústria competitiva e acelerada, e esses seriam os argumentos de sempre, contrários a uma reflexão coordenada ao ato prático de projetar, desde a Revolução Industrial, variando-se apenas as tecnologias relacionadas a cada época. Ganhar tempo, aparentemente, passou a corresponder a pensar menos. Tomar decisões rápidas passou a ser mais importante que saber estabelecer prioridades. Chama-se isso, inadvertidamente, de tradição do design moderno. Pode-se pensar como Husser ${ }^{18}$ e dizer que afinal a tradição é o esquecimento das origens. Tudo o que se consagra como tradicional tende a escamotear alguma coisa de original que, por algum motivo, revelou-se mais difícil, menos prático, menos acessível à maioria das pessoas comuns que apenas precisa trabalhar e viver. Mas, da mesma forma que um raciocínio teórico extremado e faccioso pode relegar a um plano secundário as necessidades mais básicas de trabalhar e viver, o inverso pode ocorrer. Limitar qualquer atividade a seus elementos básicos operativos pode conduzi-la a menosprezar outra necessidade básica que é pensar. Talvez tenha sido com esse sentido que Maldonado um dia definiu a atividade do designer como algo que, antes de resolver problemas, deveria criá-los e, sob essa ótica, seu enfrentamento com as ideias de Max Bill em Ulm ganharia outra dimensão bastante distinta de questões anteriores como as de Muthesius e Van de Velde e de Gropius e Hannes Meyer, uma vez que não obedeceria mais a uma tradição que imaginava sempre um confronto entre formalismos, entre posicionamentos mais ou menos industrialistas ou intuicionistas, produtivistas ou humanistas.

O próprio conceito de intuição, a exemplo da ideia de tempo, pode também ser visto sob outro ponto de vista. Generalizou-se a ideia de que o intuicionismo seria uma forma de atuação personalista de lidar com os problemas. Mas esquece-se de que maus resultados são alcançados 
também através de procedimentos metodológicos rigorosos. Não se trata afinal de defender uma ou outra forma de ação. Apenas deve-se entender que a intuição não só não se constitui em delito, como também não é simples coincidência ou fusão repentina de ideias. Ela compreende limites como a percepção pura e a memória pura e refere-se ainda ao que está no meio, a um ser, como disse Bergson, ${ }^{19}$ que se abre ao presente e ao espaço na exata medida em que visa um futuro e dispõe de um passado. ${ }^{20}$ Ou ainda, como disse Riobaldo, em Grande sertão, veredas: "O mais importante e bonito, no mundo, é isso: que as pessoas não estão sempre iguais, ainda não foram terminadas - mas que elas vão sempre mudando". ${ }^{21}$

Racionalista, crítico, anti-intuicionista, assim Bergmiller e Wollner definiram o primeiro plano para a ESDI. Bergmiller diz claramente que a Escola foi estruturada "a partir da experiência inicial de Ulm, da qual participou; de sua evolução nos anos seguintes, que sempre acompanhou; e da experiência profissional no Brasil. A disponibilidade de pessoal didático, de recursos e de materiais e equipamentos, bem como algumas restrições presentes no sistema de ensino brasileiro foram outros fatores importantes".

Outra questão importante citada por Bergmiller na ESDI refere-se ainda à manutenção das características principais do projeto estabelecido para a Escola. Se Joseph Carrero era um designer de pouca expressão pedagógica, o mesmo não poderia ser dito relativamente a Daisy Igel, ${ }^{22}$ professora admitida na ESDI após o início de seu funcionamento. A respeito desse episódio acredito que a narrativa de Bergmiller seja bastante esclarecedora:

"Edgard Decurtins deixara a ESDI e o Brasil. Recebera uma oferta de trabalho interessante na Europa e, à medida que a hipótese de ter um trabalho mais estável junto ao $\mathrm{BNH}^{23}$ não se concretizava, resolveu aceitá-la. Decurtins era uma pessoa responsável e confiável, e não queria deixar a ESDI, simplesmente. Resolveu cuidar ele mesmo de sua substituição. Conhecia Daisy Igel, arquiteta formada nos Estados Unidos, com excelentes referências, que havia estudado com Mies van der Rohe e trabalhado com Konrad Wachsmann. Mas Daisy conduziu o seu curso para um rumo totalmente diferente daquele pensado e praticado por Decurtins. Era um ideário que se baseava muito mais na New Bauhaus ${ }^{24}$ americana, sem nenhuma referência relativa à $\mathrm{HfG}-\mathrm{Ulm}$. Era como se fosse necessário retornar a um trabalho que havia sido feito há pouco tempo atrás, quando da estruturação final do plano preliminar da ESDI.
Daisy era uma professora muito dedicada e correta e os alunos do primeiro ano gostavam de suas proposições. Isso resultou numa atividade muito grande, significativa mesmo. Apesar de não ter experiência didática ela era uma professora nata. Nessa ocasião, Flávio de Aquino, então diretor da Escola, um dia me alertou sorrindo: - "Bergmiller você vai ter uma surpresa". Na verdade, levei um susto, mas aparentemente só eu. A maioria dos colegas mostrava uma atitude passiva, quando muito estavam curiosos em relação aos resultados. 0 curso de Daisy tinha abordagens tipicamente bauhausianas e, no meu entendimento, não apresentava nenhuma novidade. Em Ulm, pelo menos nos três primeiros anos, vários professores vindos da Bauhaus ensinaram, entre eles, além do próprio Max Bill, Johannes Itten, ${ }^{25}$ Josef Albers e Nonée Schmidt. Esta última trabalhou longos anos com Paul Klee ${ }^{26} \mathrm{e}$ interpretou suas matérias e atribuições em Ulm dentro de um ideário bauhausiano. Isso foi interessante para alguns, mas terminou ocasionando um conflito entre os alunos e a direção. Definitivamente, o que se queria em Ulm não era uma restauração da Bauhaus, assim como me parecia equivocado querer reassumir esses pressupostos na ESDI.

A Bauhaus fechou em 1933, a HfG-Ulm começou a funcionar em 1953, e a ESDI em 1963. 0 mundo mudou radicalmente nesse tempo: uma guerra mundial ocorreu e uma reconstrução política em escala também mundial foi necessária. Talvez só hoje esses fenômenos estejam ficando mais claros e mais bem analisados, com menos emocionalismo, permitindo uma crítica mais objetiva dessa época. No que se refere ao ensino do design, as raízes da HfG-Ulm encontram-se mesmo na Bauhaus com tendências e preocupações em se adaptar às exigências contemporâneas, levando em conta principalmente a evolução e as necessidades da sociedade industrial. Nos primeiros anos de sua curta existência, a HfG-Ulm teve uma nítida influência bauhausiana e, posteriormente, passou a valorizar cada vez mais os processos de trabalho mais metódicos buscando uma nova base em disciplinas técnicas e científicas. A ESDI foi pensada a partir dessas premissas. $O$ que sempre houve de comum nessas escolas foi a ênfase colocada no chamado curso fundamental, uma criação pedagógica do ensino do design. Desde a Bauhaus, imaginava-se que um curso fundamental bem estruturado seria a maneira correta de criar referências e bases sólidas para uma posterior formação profissional. Por isso mesmo sempre foi necessária a maior objetividade possível no enfoque pedagógico desses cursos, entendendo-se como objetividade uma compatibilidade ou uma consistên- 
cia entre o que se ensina e discute e o tipo de pessoa que se quer formar. Um bom curso fundamental serve sempre e, acima de tudo, para derrubar preconceitos, para acostumar os alunos a tentar o novo.

Nesse sentido é desejável que o corpo docente de uma escola de design seja composto por personalidades dinâmicas, criativas e idealistas. Não vejo como problemático o fato de se encontrarem nesses grupos posições diferentes, desde que não sejam radicalmente opostas às premissas e objetivos básicos da própria Escola. Sob esse ponto de vista, não era o caso de Daisy e, provavelmente, como em diversas outras ocasiões, faltou mais discussão, mais intercomunicação e mais coordenação. Após minha mudança para o Rio de Janeiro em 1967, fizemos diversas reuniões semanais com o grupo de coordenadores, e em muitos encontros informais foi possível esclarecer os objetivos comuns do curso fundamental e da formação profissional. Não me recordo de divergências maiores a partir de então com Daisy Igel. Ela participou ativamente da reestruturação do curso apresentado em 1968, que poderia ter resultado em uma melhor integração de disciplinas e interesses. Mas, como sabemos, 1968 foi um ano crítico, de contestação generalizada, época em que as discussões por vezes fugiam aos objetivos traçados para a Escola. Daisy perdeu o ânimo de participar da ESDI, ainda que não perdesse o interesse no ensino do design. Mais tarde foi para os Estados Unidos onde se dedicou a aprofundar esse interesse."

Essas questões narradas por Bergmiller ocorreram em 1968, quando se radicalizaram as posições políticas e ser jovem passou obrigatoriamente a ser sinônimo de ser rebelde. Lembro-me de músicas, de refrãos, de palavras de ordem, em especial de duas que refletem o sentido da época: "Não confie em ninguém com mais de trinta anos" e "Seja marginal, seja herói" ${ }^{27}$. Como disse Bergmiller: "Não se pode dizer quem ganhou ou quem perdeu nesse tempo cinzento. Mas quem não participou, quem se omitiu, certamente perdeu". Independentemente de suas posições, tanto Daisy quanto Bergmiller foram amplamente questionados então, a ponto de precisarem estabelecer pontos básicos de entendimento para tentar manter o projeto da Escola em andamento. Lembro-me também da aula inaugural de meu curso na ESDI em 1968. Estava habituado a certas pompas acadêmicas de outros cursos e evidentemente esperava mais uma palestra enfadonha ao fim da qual todos iríamos para a praia esquecer rapidamente que as férias haviam terminado. Mas, surpresa, o que havia no quadro-negro da sala era uma nova ordenação da Escola, com a maioria dos professores presente, com Daisy e Bergmiller explicitando como seria esse novo modelo. Pensei, pela primeira vez na vida, que talvez tivesse encontrado alguma coisa interessante no ensino. Apesar da fama e das mitologias a respeito da jovem Escola, não me pareceu que seus professores fossem modelos de pretensão e arrogância. Ousavam dizer claramente aos alunos que grande parte da responsabilidade do curso estava a seu cargo. Todos concordavam em princípio que o curso deveria ter uma essência experimental. Mas o tempo político nem sempre corresponde ao tempo da maturação. A ideia da nova estrutura não durou nem um semestre. Não admitiríamos aquela e nenhuma outra ideia. 0 tempo não era de reflexão mas de angústia e frustração e qualquer manifestação de autoridade seria, antes de mais nada, entendida como autoritarismo.

Seguiram-se as diversas e intermináveis reuniões para a reestruturação da ESDI e, nesse processo evidenciou-se uma diferença básica entre Bergmiller e Daisy. Um e outro, questionados, reagiram diferentemente. Bergmiller permaneceu, defendeu pontos de vista, expôs-se. Daisy preferiu retirar-se da Escola. Não estabeleço aqui nenhuma diferença ética ou moral entre um ou outro. Foram reações pessoais a um fenômeno sem precedentes de contestação dentro de uma escola de nível superior no país até então. Acredito mesmo que nunca mais se tenha repetido com tanta intensidade. A saída de Daisy deixou uma lacuna na Escola. Não só pela perda de uma professora jovem e criativa como também pela saída de alguém que poderia, ao longo do tempo, estabelecer uma saudável diferença com o modelo de Ulm e, talvez, contribuir criativamente para sua crítica e seu aperfeiçoamento.

Mas as coisas não são simples. Há momentos em que precisamos fazer opções e nas circunstâncias da juventude não se gosta de escolher. As mudanças na jovem Escola não foram definidas e muito menos estruturadas e restou à diretora Carmen Portinho, ${ }^{28}$ tolerante mas com uma atitude mais voltada para os aspectos administrativos, a tarefa inglória de evitar um fracasso tantas vezes anunciado, sobretudo depois do fechamento de Ulm exatamente na mesma época e em circunstâncias muito semelhantes.

0 terceiro momento importante foi a elaboração de uma proposta mais realista para o prosseguimento da Escola depois de 1968. A retomada das atividades em 1969 foi difícil e, acima de tudo, penosa. Nada do que havia sido acertado ao final de um longo processo, que passou por um esvazia- 
mento geral, funcionava. Os professores fundadores haviamse afastado da Escola, principalmente devido às divergências com os alunos ocorridas durante a discussão do currículo e também na elaboração da participação da Escola na exposição Desenho Industrial 68 - Bienal Internacional do Rio de Janeiro. ${ }^{29} \mathrm{~A}$ representação da Escola, desenvolvida pelos setores mais participativos dos alunos, foi crítica, radical, provocativa e considerada pela maioria dos professores como inadequada. No fim do ano foi baixado o Ato Institucional $n^{\circ} 5$, uma, entre outras, obra-prima do pensamento totalitário nacional. 0 ambiente dentro e fora da Escola era sombrio, desagregador e desanimador. Uma proposta relativamente emocional e pouco realista como a que foi concluída não poderia encontrar território mais desfavorável para seu desenvolvimento. A direção da ESDI e o Diretório Acadêmico tentavam de todas as formas dar alguma substância a essa proposta, mas nada se efetivava. Lembro-me que nessa ocasião estava iniciando meu segundo ano de Escola e, ao final do primeiro semestre, nenhum dos professores substitutos conseguira qualquer resultado objetivo em seus cursos. Minha turma estava então reduzida a menos da metade dos que haviam ingressado em 1968. Reunimo-nos novamente; sem a arrogância do ano anterior. Tratava-se agora de um assunto mais simples e trivial: nossa formação. Até então parecia-nos que isso era menos importante que a democracia que pensávamos ter-nos sido escamoteada, como se no antigo regime nossos direitos existissem e, subitamente, nos tivessem sido roubados.

É certo que muitos dos parcos direitos de cidadania estavam mais cerceados que antes. É certo que um considerável setor da elite, da qual fazíamos parte, estava agora submetido a processos de censura e restrição que não havia antes. Mas também é certo que a maioria da população, principalmente as faixas mais pobres, não estava nem um pouco incomodada com isso, até porque sua vida cotidiana em nada mudara. As questões de princípios e a retórica política são mesmo um território exclusivo da elite. Nessa altura podemos eventualmente pensar num paralelo histórico entre os movimentos tenentistas das décadas de 1920/30 e o que ocorreu em passado recente e ocorre hoje.

Os "tenentes de 30 ", ${ }^{30}$ assim ficaram conhecidos, sublevaram sistematicamente o país durante toda uma década em nome da restauração dos ideais republicanos. Expuseram-se, lutaram e mataram e morreram em nome desse ideal. Finalmente integraram-se à Revolução de 1930 e, próximos ao poder, aceitaram cargos e interventórias. Em pouco tempo acostumaram-se ao poder. Em menos tempo do que se poderia imaginar tornaram-se elementos de um novo jogo político que em quase nada diferia do anterior contra o qual se rebelaram. $\mathrm{E}$, em menos tempo ainda, muitos deles tornaram-se personagens políticos de uma época que só pode ser lembrada com tristeza no plano político nacional, o Estado Novo, autêntico esquife fascista dos ideais republicanos brasileiros. Os estudantes brasileiros foram, na década de 1960, os mais ativos resistentes à política totalitária implantada por um exército que tinha sido, em outras eras, uma das principais forças do pensamento republicano. Movidos por ideais difusos de uma frente política mais desordenada do que orgânica, até porque mais uma vez prescindia do povo, eles se proclamavam a vanguarda da esquerda e lutaram honestamente por uma democracia social avançada, contra o imperialismo e as multinacionais, formas externas mais visíveis do poder econômico mundial da época. Nessa situação, foram os elementos mais radicais tanto de um processo político que queria reformas, ainda que pouco claras, como da posterior resistência aos grupos civis e ao estamento militar que não as desejava. Sofreram as consequências. A exemplo dos tenentes, foram presos, exilados, torturados e muitos colegas foram mortos. Mas o tempo da elite tudo corrige e tudo assimila. Aos poucos nos acostumamos a ver os antigos radicais incorporarem-se a novos partidos, a agregarem forças com um novo tipo de personagem na nossa cena política, o líder operário real e de fato, ausente dos processos anteriores. Acostumamo-nos a comemorar com eles reconquistas democráticas como uma Constituição e o direito ao voto, muito pouco para um século de República proclamada.

Acostumamo-nos também a perder as eleições e vermos verdadeiros fantoches criados pela mídia e pela elite assumirem cargos que, ainda que tivessem perdido sua virtude original, não poderiam ser enxovalhados de tal maneira. Finalmente, parece que muitos compreenderam que as coisas são mesmo assim - amargo raciocínio que apenas concede tudo sem nada confessar -, estabeleceram alianças que em nada diferiam daquelas feitas pelos tenentes e,

\footnotetext{
Décio Pignatari apresenta suas observações, em seminário interno da ESDI sobre o ensino de desenho industrial, 1965.

Da esquerda para a direita os professores: Antonio Gomes Penna, Jorge Emanoel Barbosa, Alexandre Wollner, Flávio de Aquino, Karl Heinz Bergmiller, Lamartine Oberg e Goebel Weyne
} 


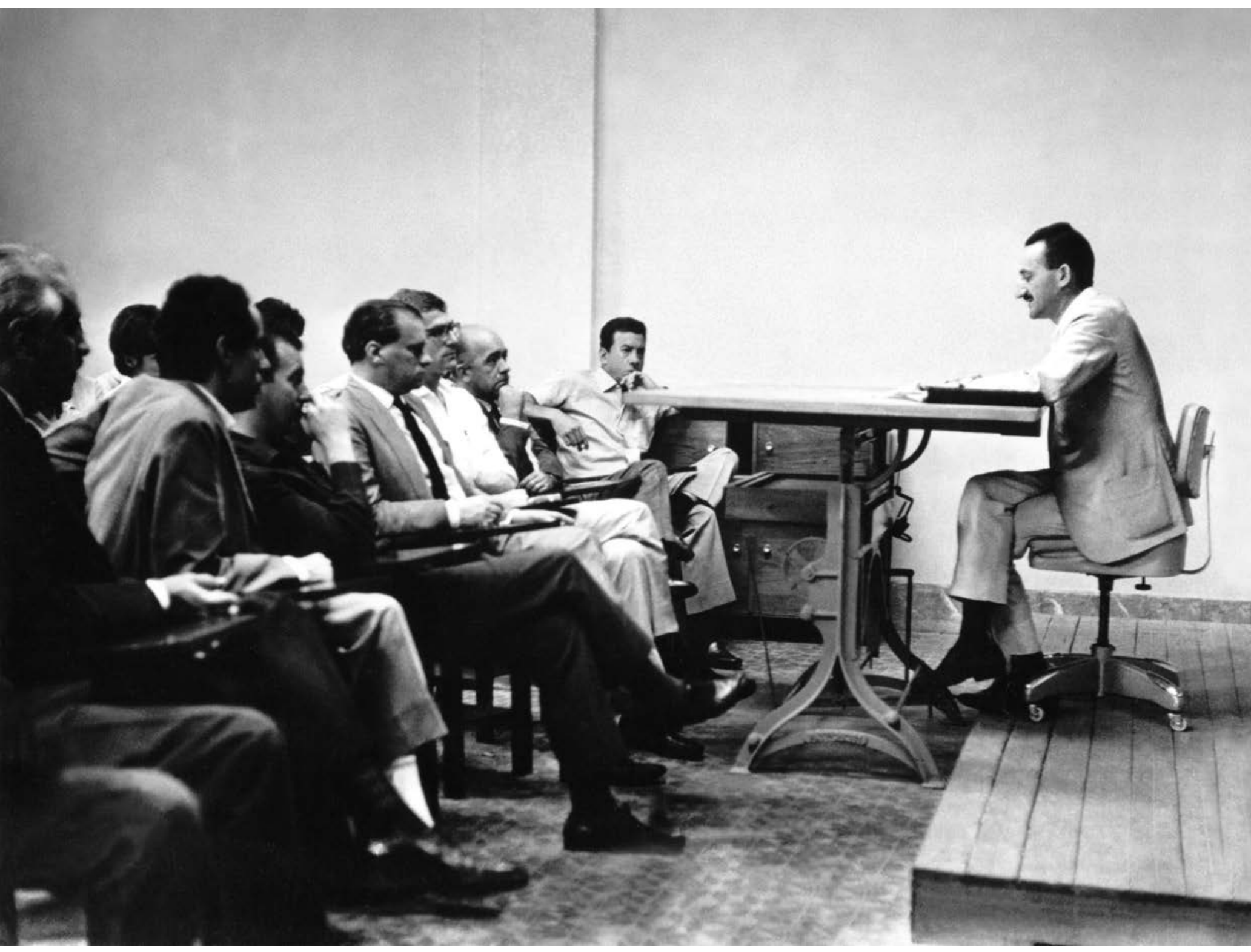


Aula inaugural na ESDI, 1968. Daisy Igel faz

explanação acompanhada por Artur Lício Pontual.

Bergmiller apresenta o curso para os novos

alunos. No quadro, a grade curricular para o

curso fundamental, $2^{\circ}, 3^{\circ}$ e $4 \stackrel{\circ}{\text { anos de DI e }}$

CV separadamente.

aparentemente, apenas ocuparam um espaço que na verdade sempre foi seu: desempenhar mais uma vez o papel de uma força renovadora que tudo tira do lugar para de novo tudo recolocar no mesmo lugar. Mais uma analogia pouco edificante com o Leopardo de Lampedusa e o sobrinho do príncipe de Salina.

Mas, deixemos as digressões de lado e voltemos à simplicidade de um grupo de jovens que diante de um impasse realiza um raciocínio elementar para uma questão nada elementar: o que fazer diante de uma total mudança de expectativas para suas vidas? Cuidar da própria formação? Como perguntou então um colega que se retirou temporariamente para uma vida no campo: "Cuidando da criação? " 31

Para isso era necessária uma estruturação mínima da Escola, de seu plano curricular, que se restaurasse alguma atividade criativa, que se começasse a pensar outra vez. Nosso grupo dirigiu-se diretamente à direção da Escola e reivindicou o retorno dos antigos professores. Pedimos professores de Projeto de Produto e de Comunicação Visual, até mesmo porque a proposta mais realista elaborada por Aloísio e Bergmiller previa a junção das duas especialidades originais na qual o curso da Escola se dividia. Essa talvez tenha sido a única consequência concreta de toda a crítica desenvolvida no ano anterior.

Foi estabelecido um acordo que previa que, a partir do segundo semestre de 1969, o segundo ano teria aulas de Projeto de Produto com Bergmiller e de Projeto de Programação Visual com Goebel Weyne. Pacificamo-nos e voltamos às aulas. Aos poucos outros professores foram retornando: Décio Pignatari, José Bonifácio Martins Rodrigues ${ }^{32}$ e outros, enquanto Renina Katz e mais alguns recentemente ingressados reestabeleciam alguma ordem curricular.
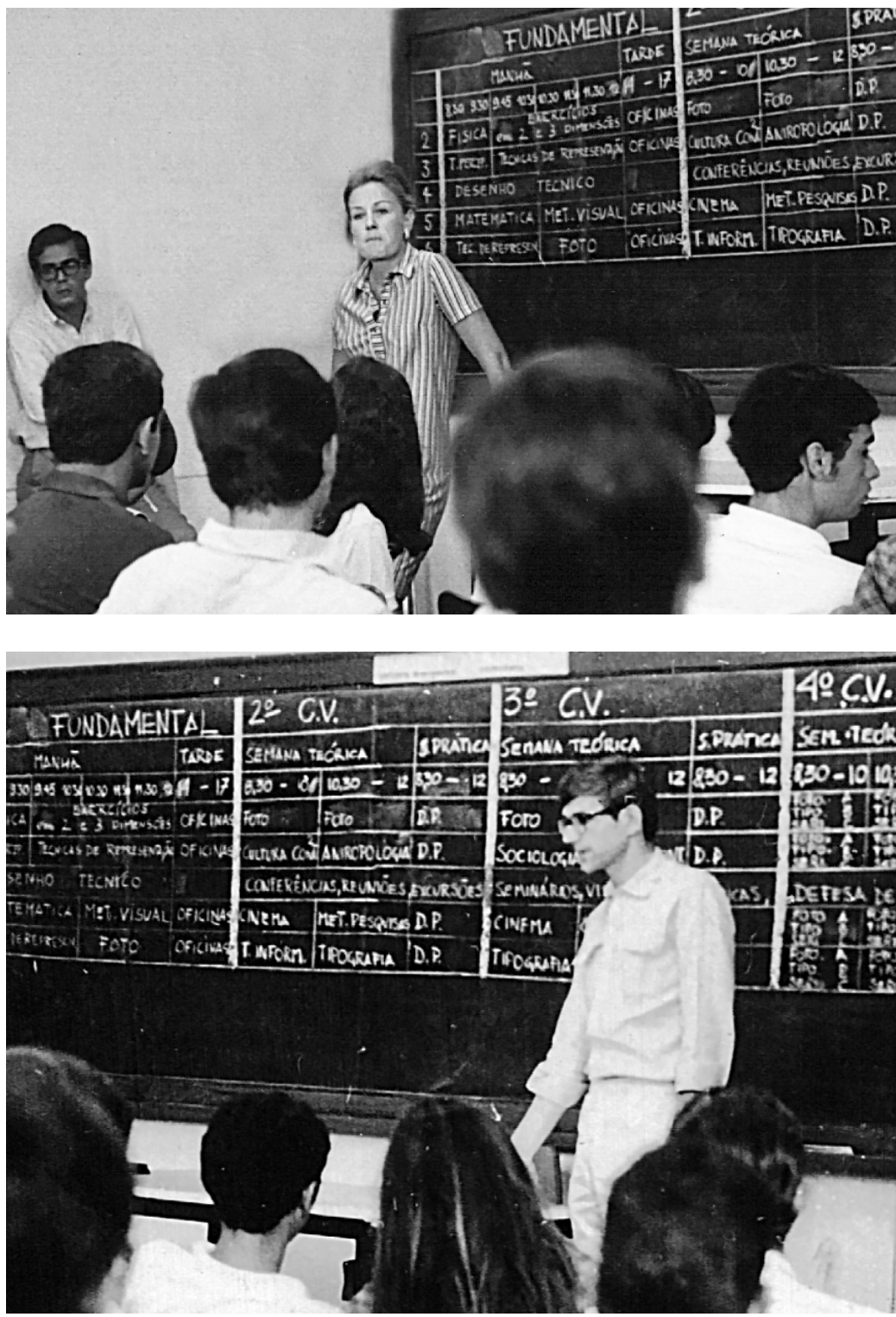
Finalmente o ano terminou com algum proveito para todos, mas a ESDI não seria mais a mesma: nem aquela prevista originalmente e nem aquela rebelada e imaginada pela movimentação política de 1968.

O ano de 1970 previa a realização de outra Bienal Internacional de Desenho Industrial e, de novo, era prevista 
Fernando Casás trabalha na maquete com os painéis para exposição da ESDI na Desenho Industrial 70, Bienal Internacional do Rio de Janeiro.

Arísio Rabin (em pé), acompanha a visualização dos primeiros painéis.'Pedrão'fez a ponte entre o IDI e a ESDI responsabilizando-se pela viabilidade do projeto.

uma participação da ESDI. Foi consenso que se deveria usar a oportunidade para um amplo trabalho coletivo que apresentasse a nova proposta e ainda uma pequena mostra de trabalhos curriculares de alunos e trabalhos profissionais de professores. Mas, acima de tudo, deveria ser apresentada a proposição da ESDI diante da nova realidade desenhada pela política nacional. Pode-se dizer que, ao lado de um posicionamento político cauteloso, foram desenvolvidas uma estrutura e uma forma bastante bem cuidadas e criativas, uma exposição relativamente simples em seu conteúdo com uma forma tipicamente representativa do formalismo técnico dos anos iniciais. Fiquei encarregado da coordenação interna do projeto e esse foi o primeiro contato de trabaIho real que tive com Bergmiller. Nessa ocasião, junto com Gláucio Campelo, meu colega de turma, tive oportunidade de praticar, em um projeto bastante real, a validade das propostas sistematizantes e metodológicas do que se poderia chamar de conceito Ulm. A exposição da ESDI foi montada em São Paulo e Brasília, como parte da Desenho Industrial 70, Bienal Internacional do Rio de Janeiro.

Depois de 1970, a Escola mudou. Talvez se possa interpretar essa mudança como o resultado de uma necessidade de sobrevivência. No entanto, até onde essas necessidades eram reais ou até onde as psicoses impostas por um regime político autoritário tornavam fatos reais, em uma área especifica, fatos genéricos em toda nossa vida é difícil dizer. Muitas das omissões e recuos observados então se perpetuaram, tornaram-se parte da maneira de ser e viver da Escola e provavelmente a questão mais complexa tornou-se a necessidade de sempre procurar consensos. Esse comportamento não foi, mais uma vez, diferente do que se observava na política geral do país. Nos piores anos do regime militar não havia espaço aparente para proposições consensuais mas, sob as aparências, por trás das oposições mais ativas e visíveis, já se desenhava o mesmo cenário de sempre que previa a reconciliação dos setores descontentados da elite numa nova forma fictícia de república e de democracia, lentamente desenvolvida nas décadas seguintes. 0 consenso
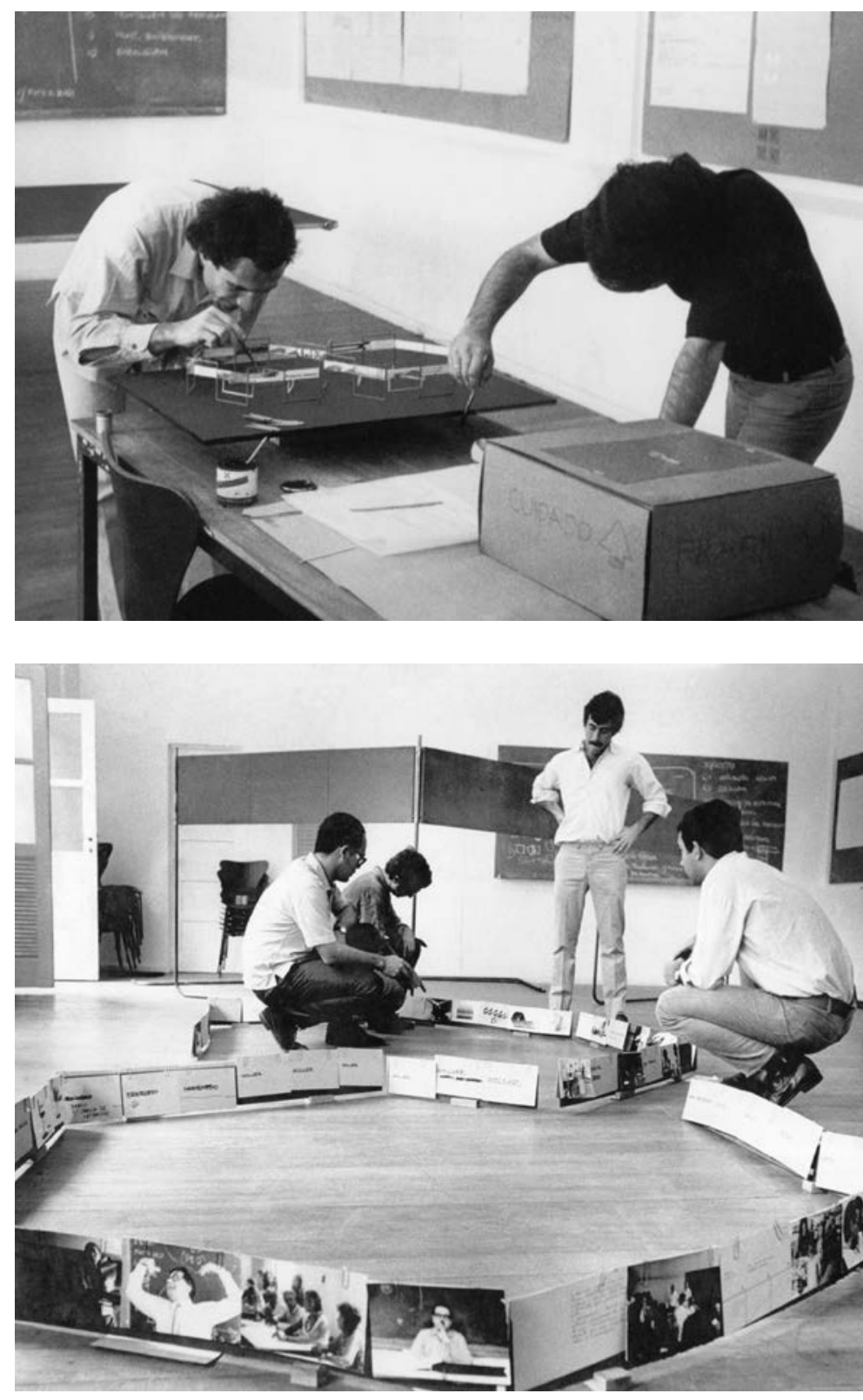
das frentes amplas, das lutas por eleições diretas, por uma nova Constituição pareciam bandeiras santas com as quais todos deveriam se alinhar sem maiores questionamentos. Esse comportamento não era muito diferente na ESDI. Os consensos são perigosos e quase sempre conduzem ao amortecimento de ideias criativas e à sua preservação através de lendas, museus, estudos acadêmicos e outros rituais criados pela sociedade, para sentir-se menos conservadora do que realmente é. A ESDI tornou-se efetivamente uma escola conservadora e a própria atividade do design também. As grandes preocupações relativas às mudanças sociais, econômicas e políticas cederam espaço à discussão de problemas como um currículo mínimo, regulamentação profissional e outras questões semelhantes.

Uma ideia que, há poucos anos, fora capaz de conduzir pessoas à ousadia de julgar as elites, de propor transformações radicais, que afirmaram ser a sua atividade imprescindível a essas transformações, foi conduzida a uma situação complicada. Seus portadores ousaram até mesmo imaginar que seria possível separar seus horizontes políticos e sua proposta de futuro do que se poderia chamar simplesmente de nível de vida. Uma nação adulta não poderia aceitar essas questões e, mesmo o Brasil não sendo adulto, também não seria possível perpetuar aqui essa atitude. Mas os recuos não precisam ser necessariamente consensuais. 0 consenso, nessas circunstâncias, quase sempre significa uma fórmula capaz de reintegrar todos numa ideia mais amena, mais civilizada, menos selvagem, portanto, muito menos criativa. Não se pode dizer que esse tenha sido um problema exclusivo da ESDI. O ensino do design no Brasil na verdade, depois da criação dos cursos que poderiam ser chamados de pioneiros como a ESDI e a FAU/USP, não avançou a não ser em aspectos quantitativos. Suas preocupações passaram gradualmente a objetivar uma equiparação com cursos acadêmicos e não uma diferenciação criativa em relação a eles. Dessa forma multiplicaram-se escolas e faculdades que cumpriam um currículo mínimo duvidoso, baseado nas experiências truncadas da ESDI, e que nada acrescentaram ao ensino. A própria ESDI, a partir da década de 1990, passou a preocuparse mais com aspectos formais e acadêmicos o que não a conduziu a nenhuma proposição inovadora.

A integração da ESDI à UERJ trouxe gradualmente para dentro da Escola a discussão de um sentido mais acadêmico de ensino. Porém não se pode dizer que a universidade seja responsável pela maioria dos problemas que a Escola apresentou nesse aspecto. É bastante cômodo atribuir a uma es- trutura maior os problemas particulares de uma instituição inserida nessa estrutura, porém, nem sempre essa é a realidade dos fatos. A UERJ não era e nem é uma universidade tão pesada e burocratizada como sempre foi descrita para justificar alguns dos problemas internos da ESDI, muitos deles presentes antes mesmo de sua incorporação à universidade. Mas, os esforços para essa integração sempre foram relativamente confusos e desordenados, permanecendo viva, durante muito tempo, a hipótese de uma autonomia que, quando proposta de fato, também era colocada em dúvida quanto à sua possibilidade prática.

Lembro-me de reuniões frequentes na ESDI, já no período em que dirigia a Escola, nas quais propus abertamente que se discutisse a hipótese de nos desligarmos da UERJ, caso as dificuldades que enfrentávamos fossem mesmo resultantes dessa integração que, em sua origem, fora realmente autoritária e unilateral. Mas as reticências surgidas diante dessa proposta mais radical eram suficientes para que ninguém se sentisse à vontade para iniciar um processo relativamente inseguro para todos. Não se deve aqui emitir um juízo moral ou ético a respeito desse fenômeno. Mas, certamente podemos afirmar que haviam desaparecido então algumas características dos primeiros anos e da fase de contestação: o idealismo e o entusiasmo, um pouco imprecisos é verdade, mas tão caros a professores como Bergmiller e Wollner, e o sentido contestatório, também impreciso, tão caro a alguns professores de segunda geração entre os quais me incluo. Estranha tarefa: exercer a direção de uma escola na qual sua vida madura estruturou-se e estabeleceu-se, sobretudo, no desenvolvimento de uma crítica que, em princípio, deveria ser produtiva mas que, muitas vezes, tornouse um instrumento tão forte e radical que poderia conduzir até mesmo à autodestruição. Nessas ocasiões sempre se poderia pensar em Maldonado e nas suas indicações de leituras, nas suas reflexões calcadas no pensamento da Escola de Frankfurt, como elemento de referência válido não apenas para justificar a continuidade como também para encontrar nela algo mais que uma simples sobrevivência. Optamos pela sobrevivência e ainda abdicamos da rebeldia, um fenômeno frequente na vida política nacional e também na vida de cada um. E, se observarmos esse panorama geral, talvez não façamos afinal tão má figura diante do que nele se desenha. Permanece algo de positivo na ESDI desde os seus primeiros anos, ainda que se observem problemas mais recentes até nesse aspecto: a possibilidade de crítica e de resposta a essas críticas ainda permanece, apesar de se apresentar 
hoje mais como uma responsabilidade institucional do que pessoal. Talvez não haja hoje na Escola o que Gramsci chamava de portadores ideológicos, de pessoas que assumam a responsabilidade por ideias mais claras e definidas, ainda que possam conter e provocar problemas. A ideologia do consenso estabeleceu-se juntamente com a transformação da Escola num sistema acadêmico mais ordenado segundo os padrões oficiais. E não é importante nessa situação, mais uma vez, procurar a culpa ou a inocência, categorias medíocres para a discussão de fenômenos que devem ser vistos como a evolução de ideias e não um mero cumprimento de normas e padrões acadêmicos.

Mas, com relação à participação de Bergmiller na ESDI, devo ainda acrescentar mais um momento que considero importante. Sua participação na coordenação da reestruturação dos critérios que regulavam os projetos de formatura. Durante muitos anos a Escola adotou um sistema que consistia na proposição pelo aluno de um projeto que deveria ser desenvolvido ao longo de um ano. Essa proposição deveria ser aceita por um conjunto de quatro professores que se encarregavam também da orientação do aluno ou indicavam ao estudante outro professor que apresentasse afinidade com o projeto proposto. Esse sistema estava naturalmente desgastado ao longo de muitos anos. Toda proposta pedagógica sofre esse tipo de desgaste e, por isso mesmo as ideias burocráticas de currículos estáveis e permanentes são sempre problemáticas. Se observarmos os cursos mais tradicionais nas universidades, verificaremos um fenômeno interessante. Os cursos de direito, por exemplo — os mais tradicionais no Brasil, ao lado da medicina —, os que mais evoluíram foram aqueles que tiveram a competência de incluir novos temas e interesses em seu currículo. Se a ideia de direito ambiental fosse aventada na década de 1970 seria encarada como uma piada, provavelmente, pois o próprio ministro do Planejamento João Paulo dos Reis Velloso foi nessa ocasião o autor de uma frase muito inquietante, ao dizer que o Brasil não deveria se preocupar com problemas desse tipo, pois ainda teria muito a poluir antes de atingir um estágio de desenvolvimento razoável. Torna-se relativamente fácil hoje criticá-lo. Mas, essa ideia reflete um espírito que não estava presente apenas nos detentores do poder. Além disso, é absolutamente real o fato de que todos os países industriais desenvolvidos chegaram a tal estágio através das mais absurdas e predatórias ações contra o meio ambiente. Assim, não era estranha a ideia do ministro que, certamente, anos depois, seria capaz de reformular os próprios conceitos. Mas, a academia demorou mais que a sociedade para mudar seus pontos de vista e incluir em seus interesses os problemas ambientais. A área do design ainda permanece bastante estacionária em relação a esse problema, e sistemas de ensino que admitem apenas o sucesso e a repetição de fórmulas servem para sedimentar mais ainda essa atitude imobilista.

Os projetos de formatura haviam chegado a esse ponto. Alguns anos antes houve a necessidade de se estabelecerem restrições a propostas que se tornavam repetitivas e rotineiras, sem nenhuma contribuição criativa significativa, sinais nítidos de esgotamento e esclerose de formas pedagógicas. Ao assumir a direção da ESDI, em 1988, pedi a Bergmiller que pensasse uma nova estrutura que possibilitasse o surgimento de outras proposições que não refletissem apenas as rotinas de um mercado de trabalho conservador. Bergmiller seria, a meu ver, a única pessoa na Escola com suficiente experiência, autoridade e maturidade para conduzir esse processo de revisão. $E$, de fato, ele começou seu trabalho com calma, reunindo o conjunto de professores responsáveis pelos projetos de formatura na época e propondo-Ihes repensar todo o processo. Conduziu tudo de sua forma habitual: amena e crítica. Ao final de um ano, havia uma nova proposição: ao invés de cada aluno apresentar uma proposta individual e isolada, os professores deveriam apresentar cada um a sua proposta, definindo áreas de interesse, organizando-as no sentido de classificar as informações necessárias. Durante um semestre haveria um trabalho coletivo do professor e dos alunos que se habilitassem à sua orientação. Esse trabalho serviria sobretudo para a definição de propostas específicas de projeto nessas áreas de interesse. Assim, cada aluno teria o seu trabalho de formatura individual, porém baseado num desenvolvimento crítico muito aprofundado, possibilitando o surgimento de pontos de vista diferenciados e inovadores.

A apresentação dessa nova forma de trabalho aos alunos poderia ser problemática uma vez que se tratava de mudar uma rotina, de reverter uma expectativa que se tornara isolada e individualista para uma nova ordem muito mais coletiva e participativa. Bergmiller, nessa ocasião, trabalhou bastante a cabeça dos próprios professores, como sempre foi característico de sua ação. Dizia que todos deveriam estar convencidos da ideia, antes de apresentá-la aos alunos, e que essa seria a única forma válida de realmente proceder à mudança. Durante as férias coordenou reuniões exaustivas até que a mínima dúvida fosse resolvida. No início de 1989, a proposta foi apresentada aos alunos e, mesmo sendo uma 
mudança radical, foi compreendida e aceita. A presença do professor mais antigo da Escola argumentando diretamente com os alunos, dispondo-se ao debate, foi fator fundamental para a aceitação, que não foi nem fácil, nem simples. Não deveria ser uma imposição, mas deveríamos todos os professores e mais a direção ser persuasivos e convincentes sobre a nova regulamentação. Lembrei-me muito dos episódios de 1968 nessa ocasião. Achei mesmo que tínhamos aprendido afinal alguma coisa, depois de tanto tempo, e os resultados desse novo processo foram extremamente satisfatórios. A natureza das propostas mudou bastante, e a rotina de aceitação pura e simples de imaginárias regras de mercado desapareceu durante alguns anos do horizonte dos alunos.

O sistema proposto era bastante claro em seu objetivo: não competia apenas aos alunos a definição e o desenvolvimento dos projetos. A formulação das áreas de interesse deveria ser bastante equilibrada para atender às individualidades, mas, ao mesmo tempo, deveria inibir o individualismo. Para isso era necessário não apenas que os professores trabalhassem mais que na antiga ordem como fossem capazes também de trabalhar em conjunto, aceitando suas diferenças. $O$ processo poderia ser até mesmo conflituoso e isso deveria ser visto como um fenômeno normal, pois, afinal, conflitos são característicos de processos criativos. Ocorreram conflitos e problemas de natureza distinta, porém, em nenhum momento, enquanto permaneceram como orientadores os professores que participaram da mudança, isso foi visto como um obstáculo maior. Até porque a qualidade dos projetos apresentados justificava qualquer percalço dessa natureza.

Porém o espírito de consenso não havia sido removido da Escola e, na primeira oportunidade, foram feitas modificações que alteraram consideravelmente a natureza do processo proposto, sem que de fato houvesse uma nova proposição. Caminhou-se para propostas coletivas de trabalho, maneira mais fácil de trabalhar menos e evitar o dissenso e a diferença. Chegou-se finalmente ao ponto de aceitar-se como tema muito mais o suporte técnico e operativo que o próprio conteúdo, outra forma de eximir-se de opiniões que

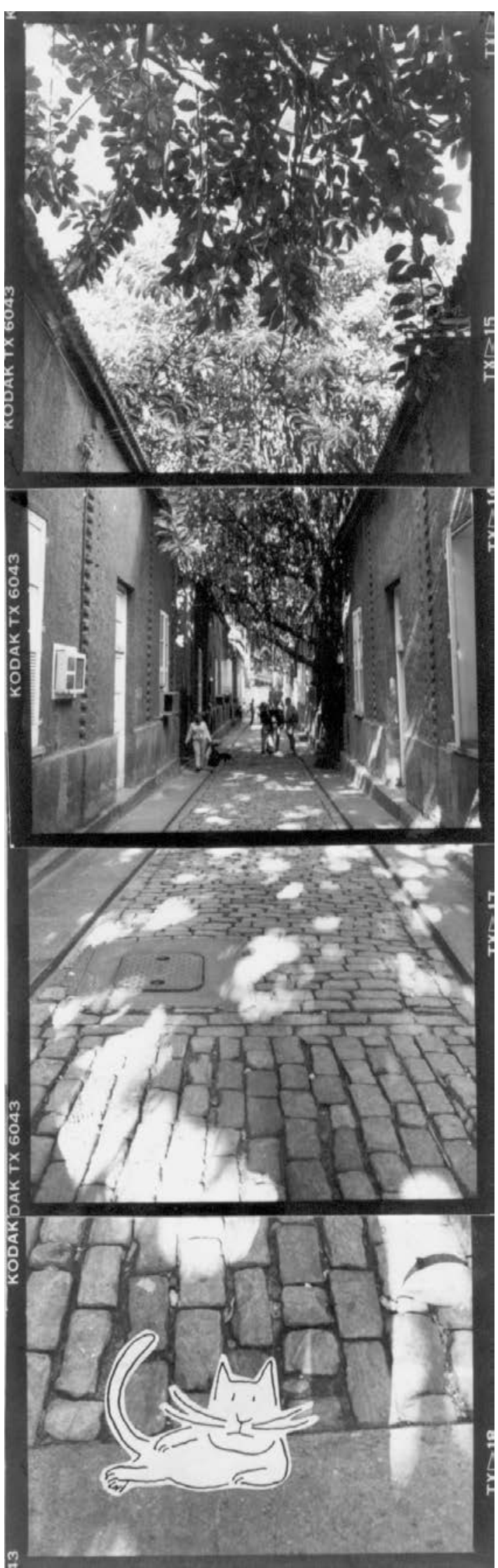


transcendam apenas a técnica e que talvez revelasse, também, pouca reflexão e pouco amadurecimento em relação à invasão dos meios digitais nas novas formas de projetar. Finalmente, depois de algum tempo, já não se sabia mais se havia ou não alguma sistemática para os projetos de formatura, ainda que sobrassem papéis e fórmulas regulatórias.

A que se pode atribuir esse processo? Apenas às pessoas? Em grande parte sim, pois afinal uma escola é constituída por professores e não alguma coisa que se sobreponha a eles. Nenhuma regulamentação da universidade pode ser apontada como responsável pelas deficiências ou equívocos do ensino. Os problemas mais reais para um ensino criativo residem na vontade ou não do grupo de professores de aceitar uma falsa ordem consensual e agravam-se quando as omissões de conflitos transformam-se no caminho para essa ordem. Evidentemente, essa é uma alternativa que preserva apenas pompas e circunstâncias. De uma escola que poderia ter aprendido a preservar as individualidades, mas não os individualismos, a ESDI transformou-se num espaço onde esta última questão é levada a um grau tão elevado que lhe restou apenas o recurso de atribuir cada vez mais importância a instâncias departamentais e burocráticas, nas quais nada é decidido e tudo é postergado. Para quem considera esse um quadro pessimista, eu apenas diria que ser pessimista hoje é quase uma obrigação cívica e republicana.

Uma análise mais precisa dos resultados do projeto da ESDI seria sempre parcial do ponto de vista tanto de Bergmiller como do meu mesmo. Eis um tema sobre o qual nos é impossível, outra vez, uma neutralidade fria e distante. Foi um projeto que interferiu nas nossas vidas de tal forma que tratá-lo através de processos de dissecação lógica e científica significaria até mesmo uma desonestidade intelectual. Às vezes é necessário salientar esse fato para que a própria leitura e a interpretação do que se escreve sejam adequadas. Certamente, a ESDI não se transformou no projeto inicialmente idealizado pelo pequeno grupo influenciado pelo ideário ulmiano. Certamente, também, ela não se dirigiu à análise e ao desenvolvimento do que poderia ser um caráter nacional para o design, um empenho sonhado por outro grupo também reduzido de pessoas, centrado nas ideias de Aloísio Magalhães. Talvez nem sequer tenha sido

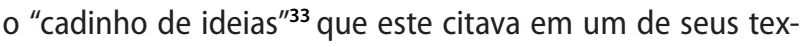
tos, lembrando José Bonifácio, o Patriarca da Independência. Provavelmente, a ESDI tem sido bem menos que isso e, ao mesmo tempo, mais que isso. Se é possível identificar no início de seu processo de desenvolvimento características de um grupo criativo, na concepção de Domenico de Masi, depois de sua assimilação pela UERJ, pode-se perceber uma contrapartida acadêmica que vai diluir muito sua ousadia inicial, seu sentido idealista e, até mesmo, a sua capacidade de inovar seu sistema pedagógico. Currículos e sistemas pedagógicos eram mutáveis e flexíveis na primeira fase, tornando-se depois encargos mais pesados e obstáculos burocráticos. Professores eram admitidos ou não através de critérios muito subjetivos, mas que permitiam certa coerência na manutenção de um sentido ideológico. Posteriormente, a introdução de concursos públicos tornou esse processo diferente e necessariamente mais neutro e distante nesses aspectos ideológicos.

Essa resposta não pode ser dada por nós mesmos, participantes ativos desse processo e, por isso, engajados e estabelecidos em nossas ideias, nossas convicções e nossos anseios. Todas as análises formuladas até agora são, na minha opinião, ainda comprometidas com visões pessoais e de pessoas que formularam suas críticas de dentro do processo. Isso não compromete, de forma alguma, sua validade. Porém, é necessário deixar claro que a neutralidade será uma característica de outros estudos, de outras formulações, de outras pessoas que não nós mesmos, professores, alunos, ex-alunos, diretores e todos os demais participantes desse projeto.

Resta ainda apontar alguns fatos. A proposta da ESDI pode não ter-se concretizado como foi imaginada por seus diferentes grupos iniciais. Entre esses grupos havia, no entanto, uma coisa em comum, ou seja, a vontade de realizar alguma coisa diferente na área do ensino superior, em um espaço de pensamento novo e inédito nesse contexto. A ESDI contribuiu decisivamente para a definição de uma ter- 
minologia para esse espaço intelectual. Sem a sua criação e sem a sua pretensão inicial, dificilmente se teria superado um estágio inicial que limitava o design a concepções individualistas e muitas delas primitivas. Suas ideias e seu debate permitiram a definição de uma autonomia do design em relação a outras atividades como a engenharia e a arquitetura. Sem a ESDI, o design permaneceria como uma decorrência de outras atividades e, ainda que se pudesse discordar, criticar, até mesmo negar, a validade dos compromissos propostos pela Escola, é obrigatório o reconhecimento de que, sem ela, o design brasileiro seria outro ou não teria existência autônoma. Alguns poderiam até mesmo argumentar que, de fato, melhor seria se tivesse sido diferente. Nós mesmos podemos hoje, crítica fácil a do tempo passado, dizer que deveríamos ter feito muita coisa diferente. Não o fizemos, e nesse aspecto qualquer crítica válida não pode começar pelo arrependimento e pela decepção, assim como não pode também começar pelo orgulho da ignorância. Lembro-me de um texto político de Antonio Gramsci que, ao analisar o fenômeno do Rissorgimento ${ }^{34}$ na Itália, citava um pensamento sobre a Casa de Bourbon então reinante, como um conjunto de pessoas que "nada esquecem e nada aprendem". Esse certamente será o caminho a ser sempre evitado.

A influência da ESDI no ensino superior brasileiro em geral talvez tenha sido menos ampla do que se pretendeu, mas, ainda assim representou certo incômodo, um fato sobre o qual foi necessário se manifestar e se posicionar. Mas, a influência da ESDI na definição e no estabelecimento do ensino do design no Brasil foi fundamental. E se a Escola apresentou, ao longo do tempo, desvios de rota e de percurso, deve-se pensar também que muita coisa, inclusive e principalmente a própria nação, também não foi como se imaginava nas décadas de 1950 e 1960.

Já que afirmamos sempre, cacoete intelectual no mínimo curioso, nossa descendência bauhausiana e ulmiana, talvez devêssemos também olhar para esse passado sob outros pontos de vista que não apenas as questões da cultura material trazida pelos objetos que projetamos.

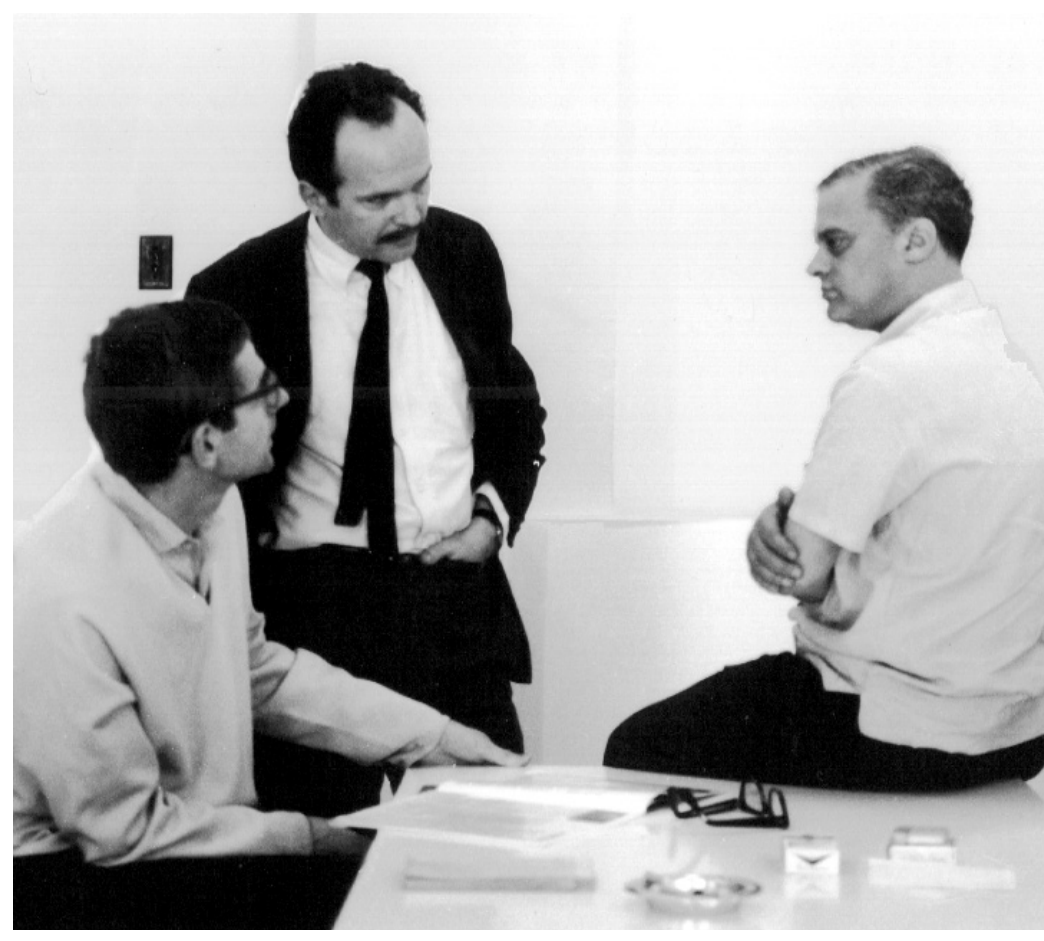

Bergmiller, Aloísio Magalhães e Flávio de Aquino, diretor da ESDI (1964-1967). Arquivo ESDI, 1966

Possivelmente um entendimento de que a vida, em todas as suas faces, seja um processo em evolução permanente, faltou na ESDI e, curiosamente, pode-se aí apontar uma inconsistência em suas origens: a dificuldade de assimilação do ideário de Max Bense e sua construção ideológica processualista. Bense foi convidado a dar cursos na ESDI, festejado, admirado e jamais compreendido em sua integralidade. Mas essa incompreensão não era consequência nem da dificuldade da apreensão de suas ideias complexas e nem de um posicionamento antagônico a elas. Era talvez a antevisão das dificuldades futuras, uma 'sabedoria precoce', uma forma de evitar um confronto com o novo de forma permanente, a dificuldade de transitar de forma amena e segura para uma nova ordem. Na vida das pessoas, assim como na vida das instituições criadas pelas pessoas que desejam mudanças de fato, não há formas amenas e seguras de mudanças. A questão da ESDI pode ser encerrada, por ora, com uma pergunta simples: - O quanto pode um grupo de pessoas impor seus princípios e ideias como forma de ser e viver a uma instituição, ou seja, a outras pessoas, sem que esse próprio grupo altere muitos desses princípios e dessas ideias originais. Qual é o preço da sobrevivência? 


\section{crises e autorreflexão}

\section{| dezembro de 1963}

Professores, mestre e alunos da ESDI reunidos no pátio da Escola tomam conhecimento do pedido de demissão de Maurício Roberto (ao centro).

Da direita para a esquerda ao lado de Maurício Roberto - Bergmiller, Silvia, Zuenir Ventura, Mario Everton, Euryalo Canabrava e Mestre Martins, Arquivo ESDI

Maurício Roberto, diretor da ESDI e presidente do IAB, se opunha a Carlos Lacerda em relação à contratação do urbanista grego Konstantinos Doxiades para viabilizar o Plano de Desenvolvimento Urbano para a cidade do Rio de Janeiro.

A revista Arquitetura, repensada por Maurício Roberto, diretor do IAB-GB, como um canal de comunicação oficial do Instituto, publicou, em abril de 1963, "Desenho Industrial na GB" reportagem saudando a realização de "um velho sonho de arquitetos".

A revista Módulo publicou em agosto de 1963 o artigo de Flávio de Aquino: "Escola de Desenho Industrial".

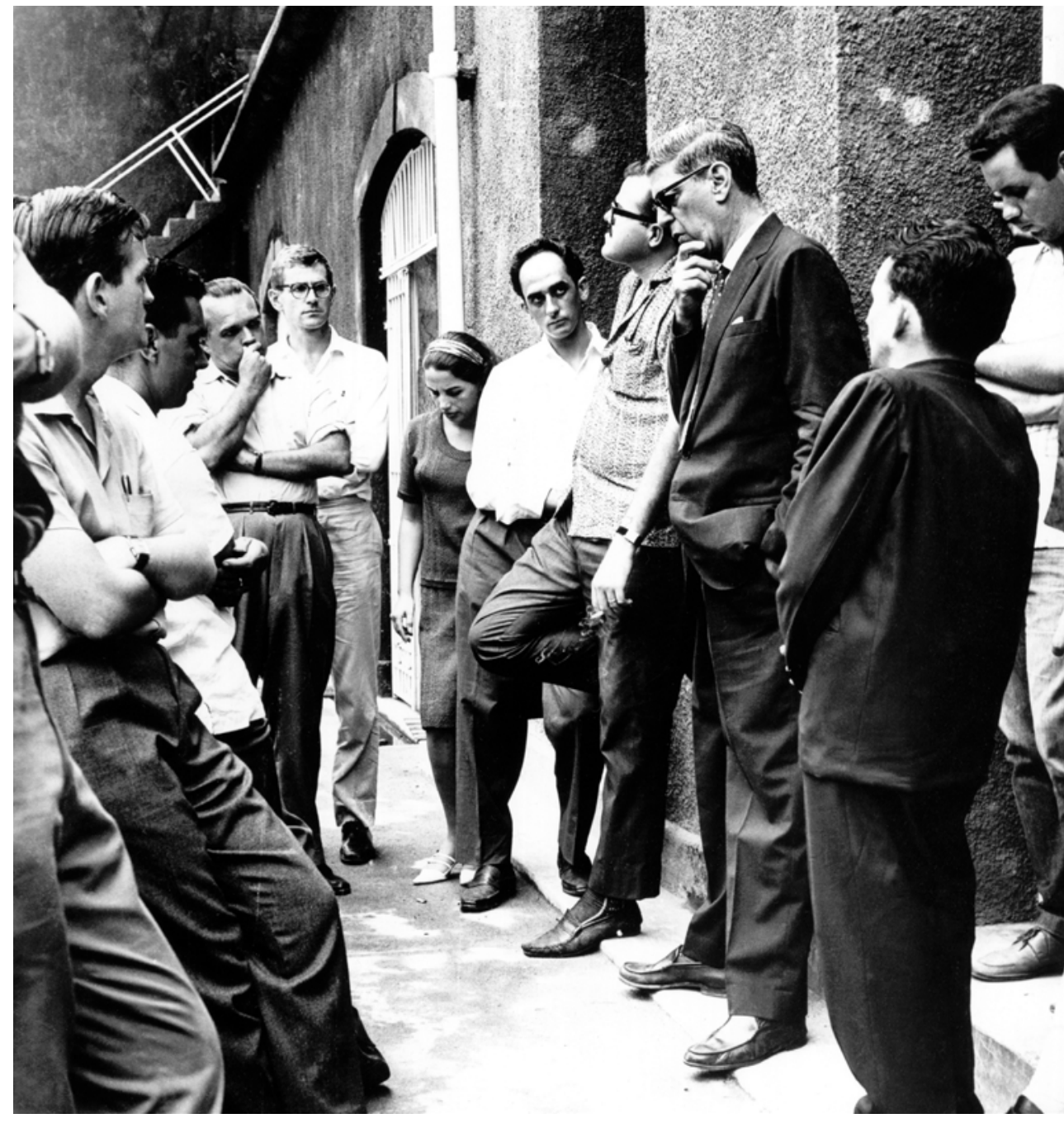


$-2-$

Sie können aber auf gar keinen Fnll als Jeitrag zum systematischen Vnterricht im Dereich des ID angesehen verden. Ba kann nicht Aufgabe einer TH sein, sich primür mit dem Gebrauch und den kulturellen Implikationen von Produkten zu beschäftigen.

Jeine ablehnende Einstellung in diesem Puakt bedeutet nicht unbedingt, dass toh ifüreine Isolierung der ID-Schulen bin. Ich glaube vielmehr, dasa die geografische Vähe einer T'I, von sozialwisaenschaftlichen und mediziniachen Fakultïten für das ID von grossem Nutzen wäre.

Jan könnte Alex vielleicht dahingehend interpretieren, dass er versucht, eine gevisase optiache Distanz zwischen der mimer Schule und der in Rio zu schaffen. Wenn das der Pall ist, so erscheint das verständlich, denn auch ich bin gegen die Verpflanzung und - e Nachahmung bestimmter pädagogiacher Auffassungen. Sie in Rio müssen Ihren eigenen Weg gehea.

Ich habe vor, im Dezember nach Argentinien zu gehen und vielleicht ein paar Tage nach Rio zu kommen. Moffentlich habe ich dann die Moglichkeit, Thre Schule zu besuchen.

Vor drei Wochen habe ich die Kopie eines Briefes von Wme. des Cressonnièrea, Sekretärin des ICSID, an Alex erhalten, in dem sie ihm mitteilt, dasa es nicht möglich sei, dass er als Vertreter der Schule in Rie an der Tagung über Designausbildung in VIm teilnähme. Ich halte das für vönig ungerechtfertigt, denn wenn eine Institution das Recht hat, daran teilzunehmen, dann ist es die Thre. Ich habe mit Prof. Misha 3lack während eines Treffens in

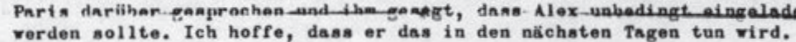

Viele Grüsse und veiterhin alles Gute

Tomis maedonado

(Tomás Ba ldonado)
| 22 de maio de 1965

Carta de Tomás Maldonado endereçada a Carl Heinz Bergmiller e Alex Wollner
Der Roktor

Carl "einz Jergniller

Mex Tollner

Facoln Superior de nesenho

Industrinil

2io de Janeiro

Rua Evaristo da Veign 95
Hocheehulo fur aestaitung

Tolefon (0731) 87339

79 Ulm (Deutochland)

Poettach 362

22. Nini 1965

Lieber Mergmiller, lieber Yollner,

neulich lintte ich die grosse Frevile, Decurtins hier zu sehen, er hat mir inhei viel ther die ESII erzählt sowie deren Programme und anderes Ninterial tagelnssen.

Gs ist pir nun ein Jedïrfnis, Sie beide sovie die anderen Mitglieder des Lehrkörpers Threr Schule zu dieser Leistung zu beglückwünschen. Ich vollte schon lange einrnl etwns Konkretes über die Schule liören, aber anscheinend hat pan uns bei der Tersendung von Informationen vergessen und so kormt es, cass es tatsächlich zum ersten lnl geschieht, dass ich Gelegenheit habe, etwns Taheres zu orfa'iren. Die Zuanmmensetzung des Lehrkörpera macht einen nusgezeichneten Eindruck. nie Leute, die ich davon kenne, sind slle hervorrngenti qualifiziert, wan-mir ala-aghr wiolitig oracheint, dena eine Schule. rird inmer dnnnch beurteilt, we gut ihre Lelirer sind. Decurting erzalilte rir anch, dass Decio Pignatari vor kurzem als Dozent berufen worden nei. Auch das hat wich sehr gefreut, denn ich schätze ihn ausserordentlieh.

7ie Bedeutung Ihrer Schule besteht meines Erachtenn u.a. darin, dass es gelwngen ist, eine unabhängige Instituti on zu errichten; unabhängig von Architekturschulen, Nkademien für hildende Künste und Technischen Mochschu linn kann rohl sagen, dass "l" und Rio die einzigen Schulen sind, die ei
solche progressive Struktur aufreisen können.

Ich war deswegen ein wenig überrnscht, als ich in der Veröffentlichung 'prociuto e linguagem', des Organs des ABDI, den Kommentar über ain Semioar 'procute Aex seine Ansicht ïber die heutige Designnusbildung darlegt. Ins, fich diest sich, Ich veis nicht, ob ich ess Auffnssung verträten, insofern, als Industrial nesign im Rnhen von T"'s galehrt werilen miisste. Ich vermute, inss Alex von dem Kurs informiert vurde, den "err fiarnich iort gibt, ain recht bescheidenes Seminnr, in dem er mit einer falsch verstanuen Terminologie versucht, in zwei Fochenstunden etmn iiber Design zu leiren.

nie Strörungen, die das Industrin] nesign anderen Institutionen zu- bzw. unterorinen rollen uni die seinen autonomen Sintus ablehnen, betrachte ic's nla renlitionär, dean In ist eine Aufgabe, die in unserer technischen Zivilisation genügend 7ichtigkeit besitzt, um "nabhängigkeit in pädagogiacher "inaicht z" rechtfertigen. "s ist natürlich nichts gegen In'Kurse zu sagen, die im nahme einer $T^{\prime \prime}$ nbgelunlten verilen nit den $7 \mathrm{iel}$, die Auahildung des Ingenieurs zu orgänzen - nber tann pilssten es schon bessere als die von Merrn Garnich sein. 
Carl Heinz Bergmiller

Alex Wollner

Escola Superior de Desenho Industrial

Rio de Janeiro

Rua Evaristo da Veiga 95

79 Ulm (Deutschland)

Postschaft 362

22.Mai 1965

Outro dia tive o grande prazer de ver Decurtins aqui; ele me falou muito sobre a ESDI, bem como seus programas e deixou vários outros materiais.

É um grande prazer para mim felicitá-lo, tanto quanto aos outros membros da sua escola por essa conquista. Eu queria ouvir algo de concreto sobre a escola há muito tempo, mas, aparentemente fomos esquecidos nessa transmissão de informações, e esta é a primeira vez que tenho a oportunidade de saber mais. A composição do corpo docente dá uma excelente impressão. As pessoas que conheço são todas altamente qualificadas, o que me parece ser muito importante porque uma escola é sempre julgada pela boa qualidade de seus professores. Decurtins também me disse que Decio Pignatari tinha sido chamado brevemente como palestrante. Isto também muito me alegra porque eu realmente $\mathrm{o}$ aprecio.

A importância da sua escola é, na minha opinião, conquistada na medida em que conseguiu se estabelecer como uma instituição independente; independente de escolas de arquitetura, academias de artes plásticas e faculdades técnicas. Pode-se dizer que Ulm e Rio são as únicas escolas que podem ter uma estrutura tão progressista.

Fiquei, portanto, um pouco surpreso ao ler no "produto e linguagem", o órgão do ABDI, o comentário sobre um seminário no qual Alex apresentou sua visão sobre a educação em design hoje. Eu não sei se interpretei mal, mas é como se ele acreditasse que os estudantes de TU Stuttgart estavam certos em sua opinião de que o Industrial Design deveria ser ensinado no âmbito das TU's. Eu suspeito que Alex tenha sido informado sobre o curso que o Sr. Garnich dá lá: um seminário bastante modesto, no qual ele tenta com uma terminologia incompreensível ensinar sobre projeto ao longo de duas semanas.

Correntes, que o Industrial Design assume em outras Instituições. Subordinando-se e rejeitando seu status autônomo, considero esta atitude reacionária, porque ID é uma tarefa suficientemente importante em nossa civilização técnica para justificar independência em termos educacionais.
Claro não há nada contra um curso de ID vinculado a uma estrutura. Mas uma TU realizada com o objetivo de complementar o treinamento de um engenheiro - teria que ser meIhor que o do Sr. Garnich.

No entanto, eles não podem ser considerados como realizadores de uma contribuição para o ensino sistemático no campo ID. Não pode ser tarefa de uma TU lidar principalmente com o uso e as implicações culturais dos produtos.

Minha atitude negativa com relação a este ponto não implica necessariamente em que eu seja um adepto do isolamento de uma escola de ID. Pelo contrário, acredito que a proximidade geográfica de uma TU, de faculdades de ciências sociais e ciências médicas seria de grande utilidade para o ID.

Pode-se talvez interpretar Alex no sentido de ter feito uma certa distância óptica entre a escola de Ulm e a do Rio. Se for esse o caso, parece inteligível, pois eu também me oponho ao transplante e à imitação de certas concepções pedagógicas. Vocês no Rio devem seguir seu próprio caminho.

Eu planejo ir para a Argentina em dezembro e talvez alguns dias para o Rio. Espero que eu tenha a oportunidade de visitar sua escola.

Três semanas atrás, recebi uma cópia de uma carta da Sra. Cressonnières, secretária do ICSID, para Alex, que the disse que ele não podia participar como representante da escola no Rio no desenvolvimento da educação de design em Ulm. Eu acho que isso é completamente injustificável, porque se uma instituição tem o direito de participar, é sua. Falei com o Prof. Misha Black durante uma reunião em Paris e disse-Ihe que Alex deveria ser convidado. Espero que ele faça isso nos próximos dias.

Meus cumprimentos e os melhores votos,

Tomás Maldonado 
De junho de 1968 a agosto de 1969 a Esdi passou por 14 meses de um intenso, turbulento e penoso processo de revisão. Passados os anos o que esse tempo revela de importante é uma enorme vitalidade.

("Assembléia Geral" in Esdi biografia de uma Idéia)

A participação da Esdi na DI 68, teve uma grande repercussão na mídia impressa e motivou uma série de discussões sobre design e ensino a apartir de indagações sobre produção e consumo.

A exposição não se constituiu no encerramento das discussões ou do trabalho em si, inaugurou um processo.

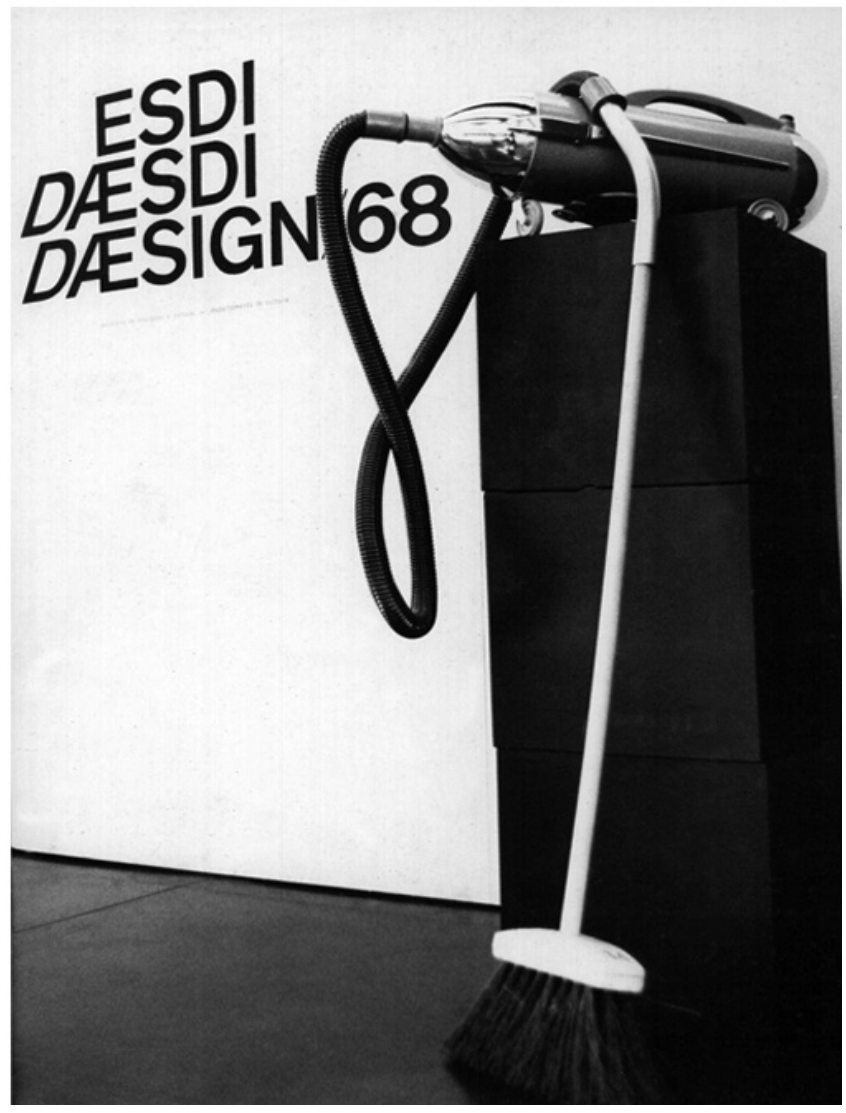

0 título da exposição registra a iniciativa do Diretório Acadêmico. Títulos e instalações refletem a inquietação com o modelo econômico e hábitos de consumo vigentes.

Os estudantes trabalham os textos lado a lado com Décio Pignatari e Zuenir Ventura: "0 banquete do consumo".

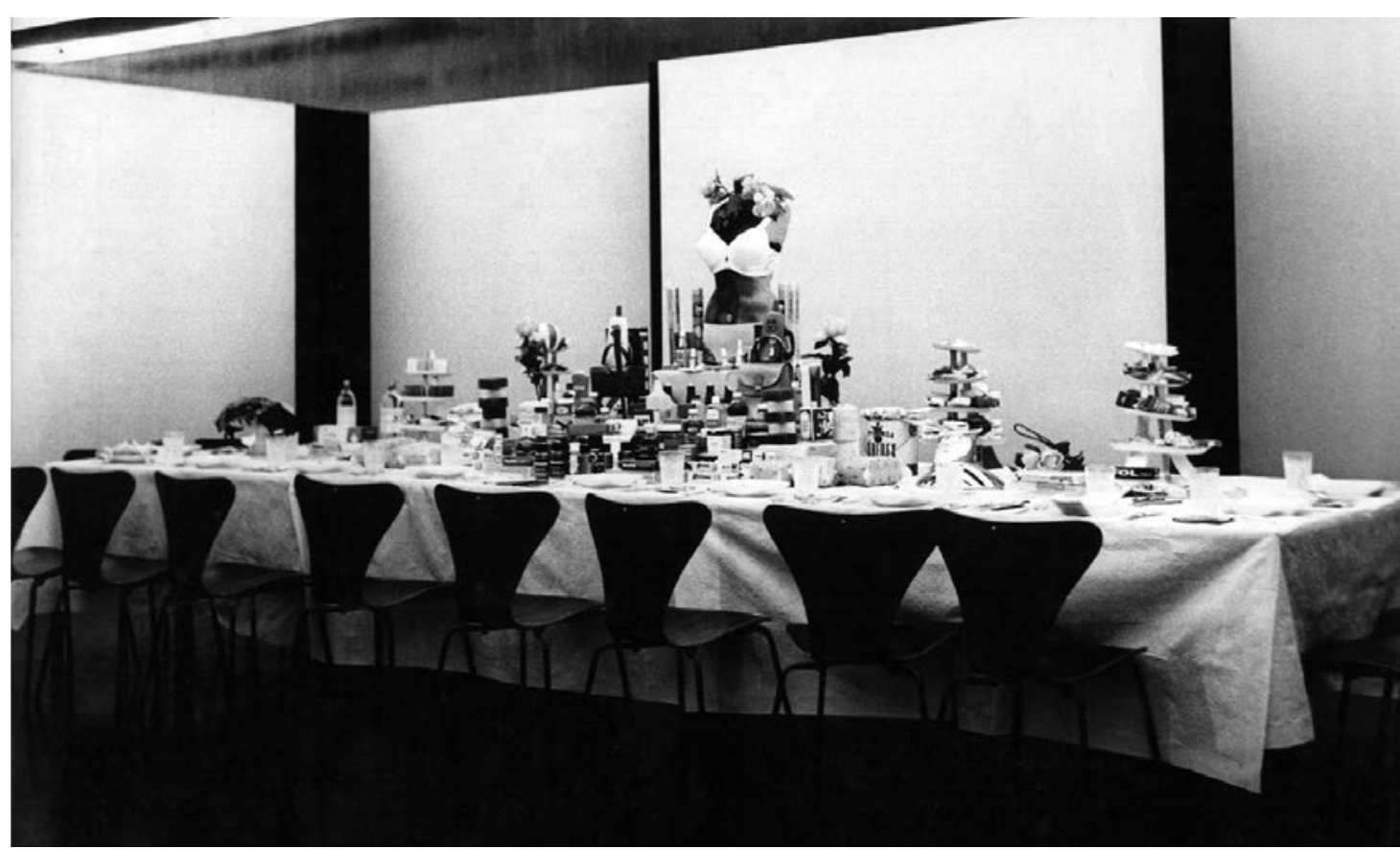


Professores e alunos sob a coordenação de Bergmiller planejaram a participação da Esdi na DI 70. Pedrão fez a interface ESDI/IDI.
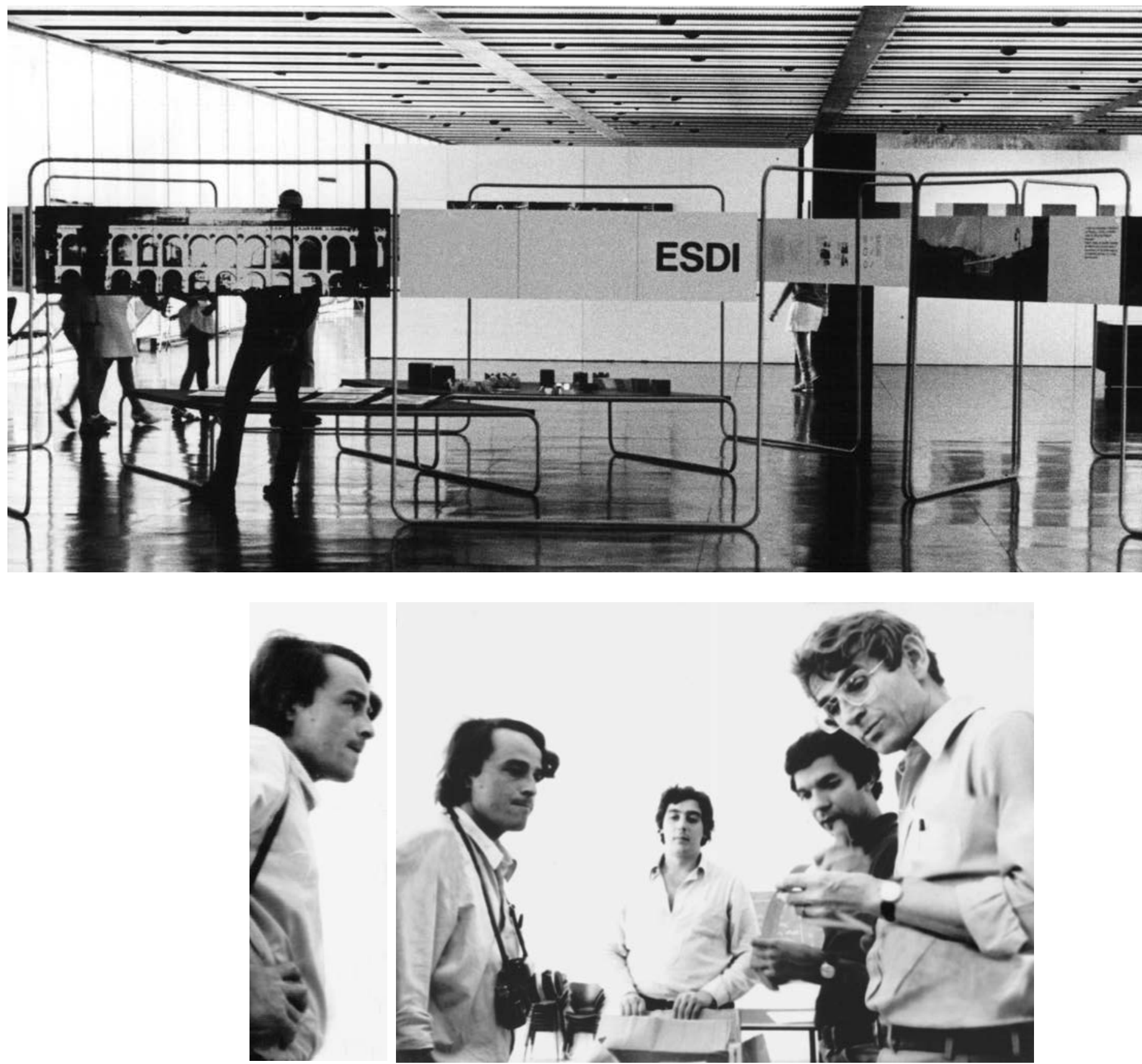

Roberto Maia, professor de fotografia, mobilizou os esdianos a aceitar o desafio de fotografar e fazer as ampliações da mostra no laboratório da ESDI. Alguns alunos dessa geração são fotógrafos profissionais. 

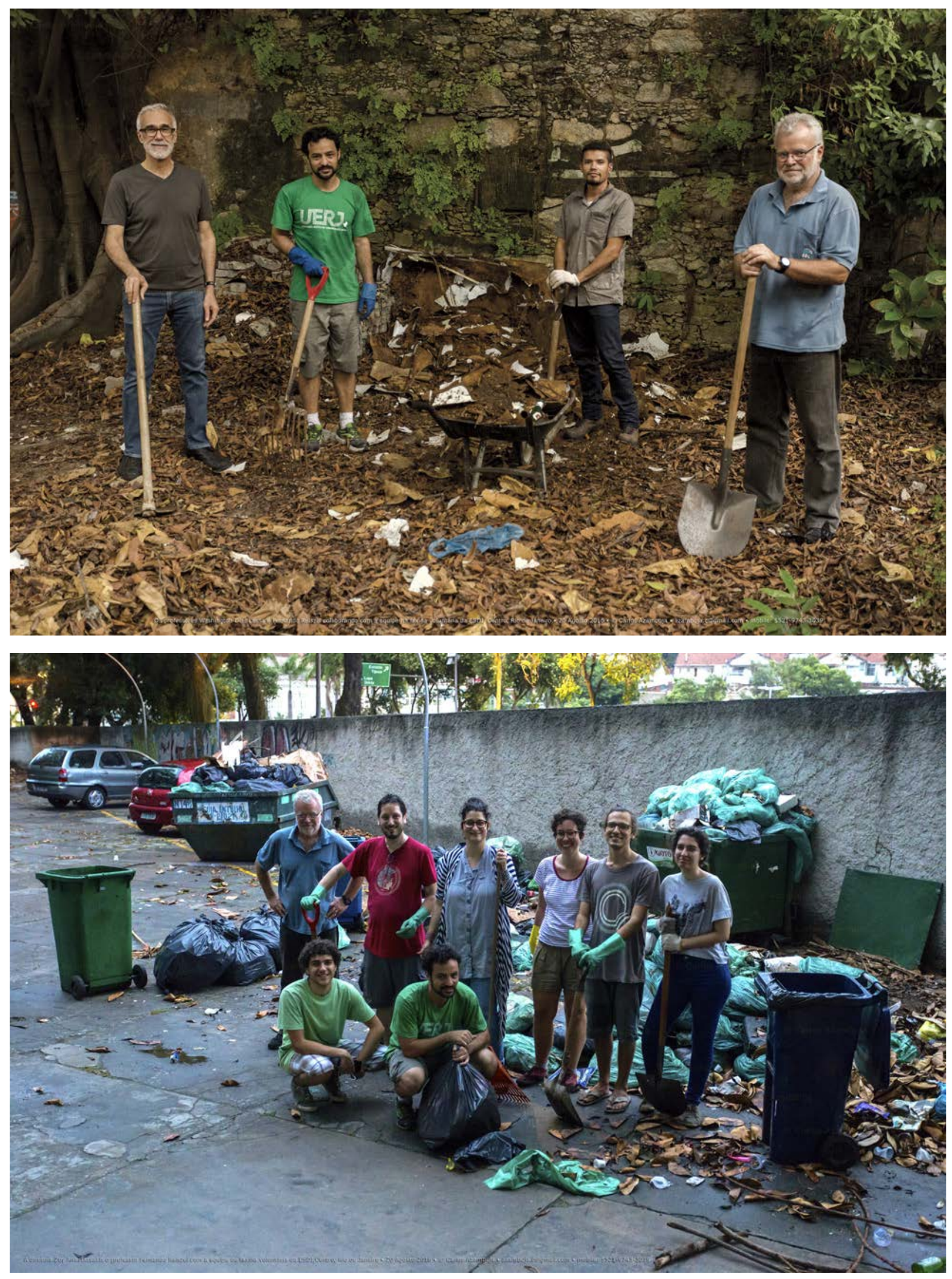
| 20 de agosto de 2016

Faxina Voluntária

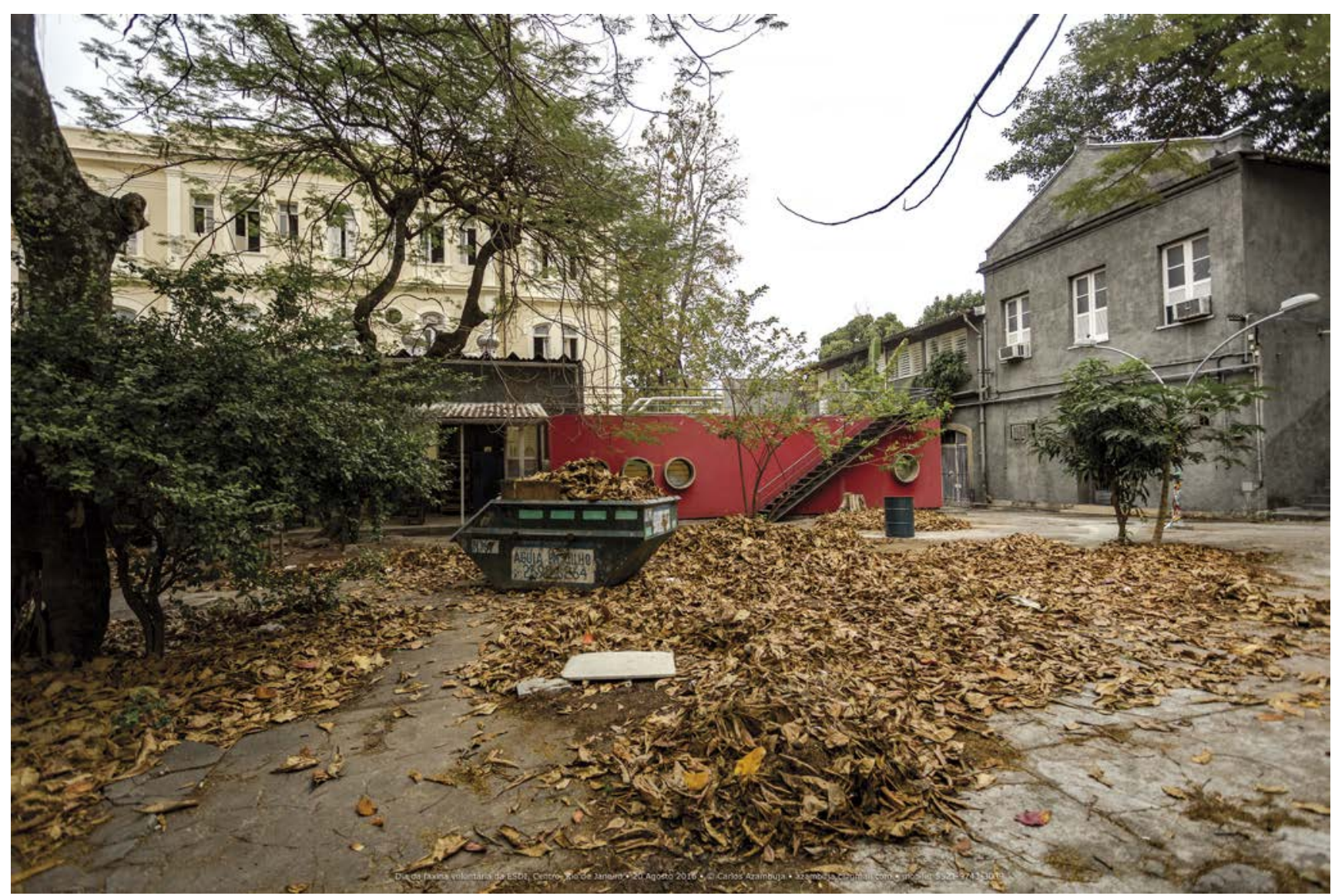

Um mutirão realizado por ex-alunos, alunos, professores, ex-professores e a direção da ESDI viabilizou uma faxina voluntária.

Fotos CARLOS AZAMBUJA, exdiano, fotógrafo e professor da UFRJ.

Da esquerda para a direita o professor Washington Lessa, os alunos Gabriel Borges e Marcelo Souza e o professor Fernando Reiszel.

Em pé, o professor Fernando Reiszel, o aluno Philippe Leon, a diretora Zoy Anastassakis e os alunos Roberta Guizon, André Aranha e Daniela Tinoco; agachados os alunos Lucas di Nonno e Gabriel Borges finalizam a jornada de faxina. 

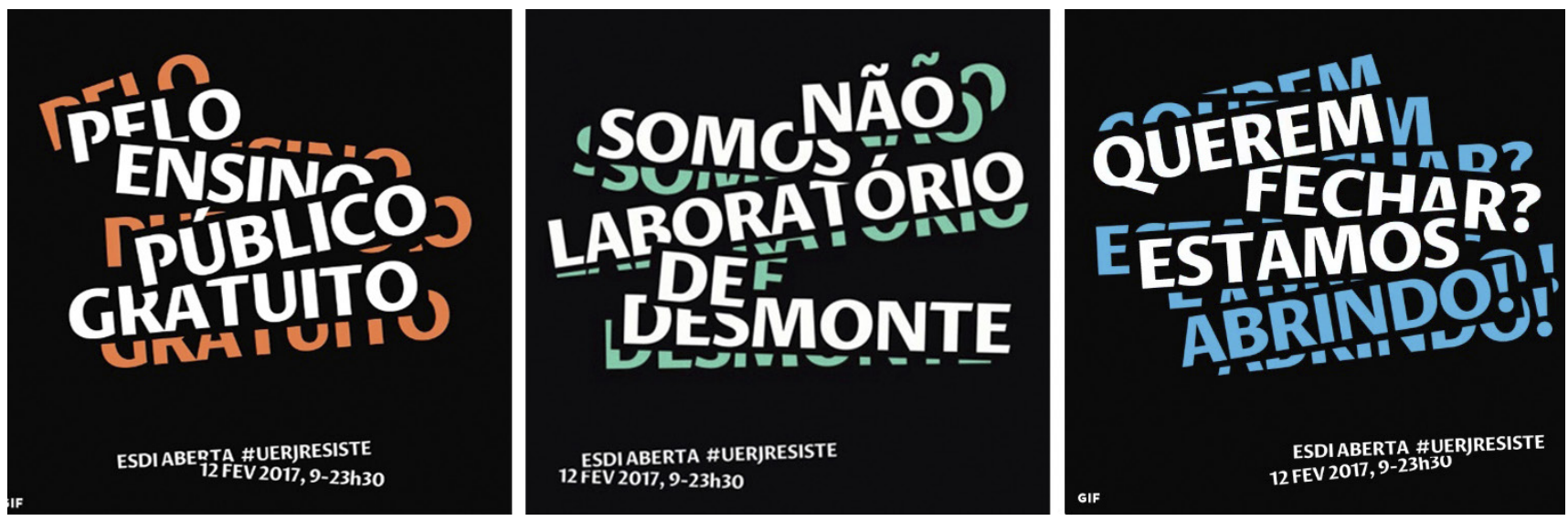

\section{[... $2004-2017]$}

Quando esse trabalho teve início, em 2004, Bergmiller deixou bem claro que não queria fazer um livro de documentos, nem um livro sobre pessoas. Em 2006 com o texto consolidado o escopo das 30 imagens iniciais foi ampliado para 200 seguindo o mesmo critério de abordagem.

Zuenir Ventura, "O choro ou a crônica". O Globo, 11.02.2017

"O evento de mobilização que a Escola Superior de Desenho Induastrial (Esdi) promove amanhã contra a crise na UERJ e, em conseqüência sua própria crise, é um admirável esforço de resistência civica de alunos e professores, mas ao mesmo tempo um triste capitulo de uma gloriosa história."
10 anos se passaram. Em fevereiro de 2017 a direção da Esdi (Zoy Anastassakis e Marcos Martins), o alunado e corpo docente realizaram um evento intitulado ESDI ABERTA \# UERJ RESISTE. A convocação pelas redes sociais não deixava dúvidas sobre o caráter de resistência da proposição. Dois dias de atividades intensas e diversas com explícitas manifestações de referência ao significado da ESDI para o Design e o exercício da atividade no Brasil.

Karl Heinz Bergmiller seria homenageado e eu fui convidado a propor um tema e dar uma aula. Nesse momento fica muito claro para os esdianos a presença marcante de Bergmiller nas situações em que uma atitude firme de comunicação da instituição de ensino com a sociedade se faz necessária. Momentos de crise e autorreflexão são um continuum na história da Esdi.

Desvinculados do código inicial — não mostrar documentos e não falar de pessoas, seguem fatos relacionados a Esdi e a Bergmiller resgatados a partir de fevereiro de 2017. Momentos distintos, situações diversas conectadas pelo caráter de resistência e proposição coletiva.

Pedrão, 2017 


\section{Homenagem a Bergmiller}

[apresentação às novas gerações]

A direção da Esdi nos motivou a resgatar uma expressão de Karl Heinz sobre as atividades de 1968: "Quem não participou, perdeu!"

Debates e reflexões internas, trabalho coletivo, entusiasmo e ações positivas em defesa de uma idéia. Na participação da Esdi na Desenho Industrail 68, e na Desenho Industrial 70, Zuenir Ventura e Décio Pignatari nos ensinaram a escrever, Roberto Maya a fotografar e documentar exaustivamente.

Ambas resultaram em Manifestos de Superação. Era importante comunicarse, participar e propor. Extrapolar as fronteiras do design e conectar-se com a cidade, com o país e o mundo. Comunicar-se, continua sendo importante em 2017.

Os alunos, hoje tentam incansavelmente nos ensinar o valor das redes sociais e Bergmiller está aqui, com o entusiamo de sempre e seus colaboradores acreditam em trabalho colaborativo e ações positivas.

A Escola Superior de Desenho Industrial (Esdi) convida para
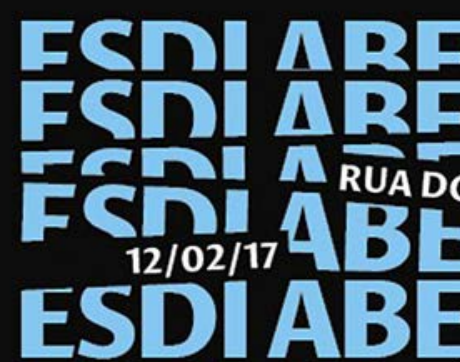

RUA DO PASSEIO 80 $12 / 02 / 1$
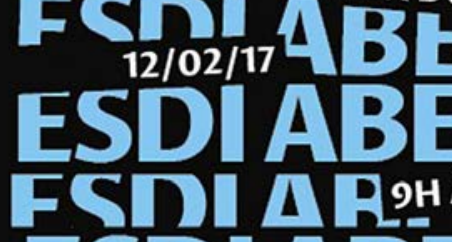

$\rightarrow$
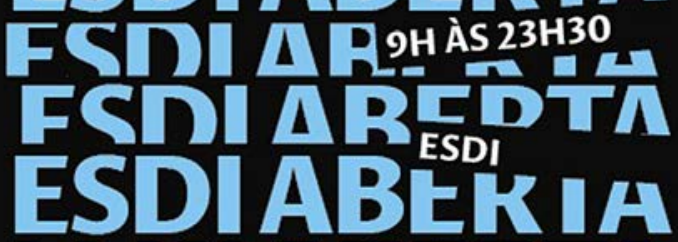

$\square \square \square$

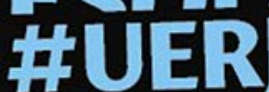

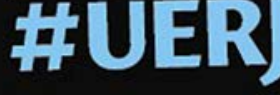

Escola Superior de Desenho Industrial Rua do Passeio 80 - Centro, Rio de Janeiro
A Escola Superior de Desenho Industrial da Universidade do Estado do Rio de Janeiro convida a todos para a cerimônia que marca alguns eventos significativos para a sua comunidade:

\section{ABERTURADENOVOACESSO} PARAARUA DOPASSEIO

REATIVAÇÃO DAASSOCIAÇÃODE PROFESSORES, EX-ALUNOS EAMIGOSDAESDI LANCCAMENTODENOVO SITEEIDENTIDADEVISUAL HCMENA KARLENAGEM AO PROFESSOR
KAINZ BERGMILLER

A cerimônia acontecerá no dia 12 de fevereiro de 2017 , às 18 horas, como parte do evento ESDI ABERTA \#UERJRESISTE.

0 material de divulgação do ESDI非ABERTA foi projetado por ex-alunos e produzido nas oficinas da Escola. 


\author{
Karl Heinz Bergmiller homenageado no evento \\ ESDI ABERTA \# UERJ RESISTE conversa com esdianos.
}

Algumas semanas atrás a Silvia Steinberg telefonou: Karl Heinz, vai ter um evento na ESDI no dia 12 de fevereiro e a gente espera você lá! Respondi de imediato - sim, eu vou, estou feliz de ir, já imaginei que algo estava pintando, porque o Nelson Motta, uns dias antes escreveu na coluna dele: "vão fechar a Escola dos meus sonhos", aproveitando para xingar o governo. Eu jamais podia acreditar, alguém tem coragem de fechar a Esdi, mas o que ele comentou sobre governo ladrão estou endossando.

A Silvia me esclareceu mais detalhes sobre o evento e eu fiquei aliviado, até contente com a forma como estava sendo programado este protesto. Um programa digno de uma ESDI que tem o seu bom nome a preservar. Fiquei feliz também em saber que os velhos esdianos estão se armando, mas não em termos de revolta, resultando em quebra-quebra, pelo contrário, querem proteger a sua Escola de qualquer ameaça, de qualquer origem.

Outro dia a Silvia ligou de novo, lembrando do evento no domingo dia 12 e disse: o pessoal da Esdi gostaria que você falasse um pouco com seus velhos alunos, colegas e amigos e também com as turmas novas. Ah! Eu imaginei - só queria chegar, dando beijos e abraços...

Achei que o Pedro, melhor do que ninguém, saberia situar nossa Escola nesse contexto político/econômico/caótico, num período em que todos nós estamos sendo atormentados, em qualquer área: segurança, saúde, educação. Pensei que o Pedro tem tarimba para definir quem nós somos, de onde nós viemos e quais são agora as alternativas para sair deste caos - e eu vou atrás dele.

CRISES, já passei por muitas desde que estou no Brasil. Não quer dizer que eu me acostumei. A maioria eram crises econômicas, quase sempre de origem política. Senti isto, ain- da mais na pele, quando trabalhava para as indústrias paulistas defendendo sempre nossos anseios.

Crises nos desafiam a procurar métodos e caminhos novos. Crises devem ser enfrentadas com lucidez, com ações racionais. Dominar crises requer também criatividade. GENTE, isto faz parte do nosso repertório - belo exemplo o que está acontecendo à nossa volta! A própria Esdi nos seus 55 anos de existência teve que enfrentar várias crises, algumas não eram propriamente crises, eram mais autoquestionamentos. Isto é saudável. A Esdi sempre soube ser explícita e procurou adaptar-se à contemporaneidade. A sociedade industrial, neste meio século, sofreu transformações e conseqüentemente o ensino necessitava revisões.

Quando a Esdi foi integrada a Uerj perdeu-se algo em sua autonomia, mas acho que a Esdi não perdeu sua identidade. Muitos de seus ex-alunos tornaram-se professores e diretores da Escola, conferindo a ela um aval de confiança.

Voltando a falar de crises, a Esdi enfrentou uma profunda crise em 1968, nos anos pioneiros da Escola, na fase da sua afirmação. Eu classifico essa crise sempre como 'produto importado'porque chegou da Sorbonne.

A crise universitária de 68 se alastrou mundo afora e inclusive questionou o ensino universitário no Brasil. A Esdi não conseguiu ficar de fora, apesar de ser uma instituição inovadora, sem aqueles ranços convencionais. Me permitam o tom de arrogância, a Esdi 'estava anos luz à frente'de muitas Escolas. Justamente isso fascinou alunos como o próprio Nelson Motta.

Nossos jovens agitadores argumentaram na época um pouco inconseqüentemente: "A Esdi é uma escola nos moldes alemães - não pode dar certo no Brasil"! Lembrando que na escola de Ulm, a maioria de seus professores e alunos 
eram estrangeiros e repito - o movimento estudantil nasceu onde? Em Paris.

A Esdi sempre foi uma instituição democrática. Juntamos nossas pranchetas formando um $U$ que virou uma grande mesa de conferências e discutimos, discutimos. Professores e alunos, fazendo propostas e propostas, mas nada de construtivo surgiu. Não devemos esquecer as circunstâncias políticas dessa época. Vigorava a plena ditadura. A turma estava envenenada. Foi difícil, delicado e até arriscado discutir sobre as medidas do regime militar e suas consequências e ao mesmo tempo defender nossas idéias e ideais, nossos objetivos em formar um novo tipo de profissional, chamado designer, até então desconhecido no Brasil.

As aulas pararam durante um semestre. No mesmo ano o IDI planejou a primeira Bienal Internacional de Desenho Industrial no Museu de Arte Moderna do Rio de Janeiro e determinou um espaço para a Esdi se manifestar, formalizar idéias, expor suas preocupações! A Esdi fez isso com entusiasmo e sucesso. Montou um pavilhão conceitual, fez a crítica ao consumo, denunciou duramente o empresariado, comércio e indústria por causa de seus produtos 'de fora', copiando vergonhosamente ou pagando royalties e não investindo numa tecnologia própria. O setor da Esdi fez um verdadeiro contraste com o evento que salientava o chamado good design tanto num panorama nacional como internacional. Acho que a exposição melhorou a autoestima dos integrantes da Escola.

O tempo que passa ajuda a refletir melhor sobre o movimento estudantil de 68. Acho que, quem participou, ganhou! Quem tirou o corpo fora perdeu algo na sua formação como designer. Nossa premissa era a de formar um tipo de profissional com um abrangente conhecimento tecnológico, com a capacidade metodológica de analisar e desenvolver projetos, mas que tivesse além disso uma qualidade básica e pessoal $O$ senso da responsabilidade social.

$\mathrm{Na}$ Esdi no seu programa de ensino, foi sempre evidente a ênfase na formação da personalidade.

A crise de 68 acabou e eu não vou continuar batendo nessa tecla. Vendo o convite Homenagem ao Professor Karl Heinz Bergmiller" levei primeiro um susto, mas raciocinei logo - ainda estou entre vocês, sim estou aqui - e tenho vontade de abraçar a todos!

Meu tarablho sempre foi ligado a equipes. No ensino, na pesquisa, nos projetos para as indústrias e instituições. Eu tinha sempre sorte de ter bons colegas e colaboradores em volta de mim. Citar nomes seria uma lista enorme e provavelmente por falta de uma ou outra citação ficaria delicado para mim. Mas tem duas personalidades que não dá para isolar do meu trabalho: Goebel Weyne e Pedro Luiz Pereira de Souza. Ambos, acima de tudo, grandes amigos. Goebel era um profissional excepcional, muito criativo e muito neurótico - coisa de gênio. Mas nós trabalhamos sempre em harmonia, durante muitos anos na Esdi, no IDI e na Escriba via ponte aérea. Pedro foi meu aluno, estagiário, colaborador e coor denador adjunto no IDI, tornou-se meu chefe como diretor da Esdi. Em muitos projetos complexos o Pedro assumiu o papel de maior responsabilidade: fez parte na formulação das propostas, no desenvolvimento dos projetos e supervisionou a implantação.

Aprendi muito com meus colegas e colaboradores. Aprendi sempre na indústria, aprendi com meus alunos, e se alguém me pergunta hoje - 0 que você fez de importante? Vou relatar tudo o que NÓS fizemos. Obrigada pela homenagem e um abraço a todos que me acompanharam todos esses anos. 


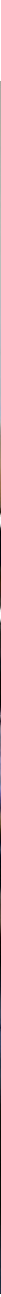

Pedro Luiz conversa sobre "Design Moderno, tempo e perspectiva", após aula no evento ESDI非ABERTA. Fotos PHILIPPE LEON 


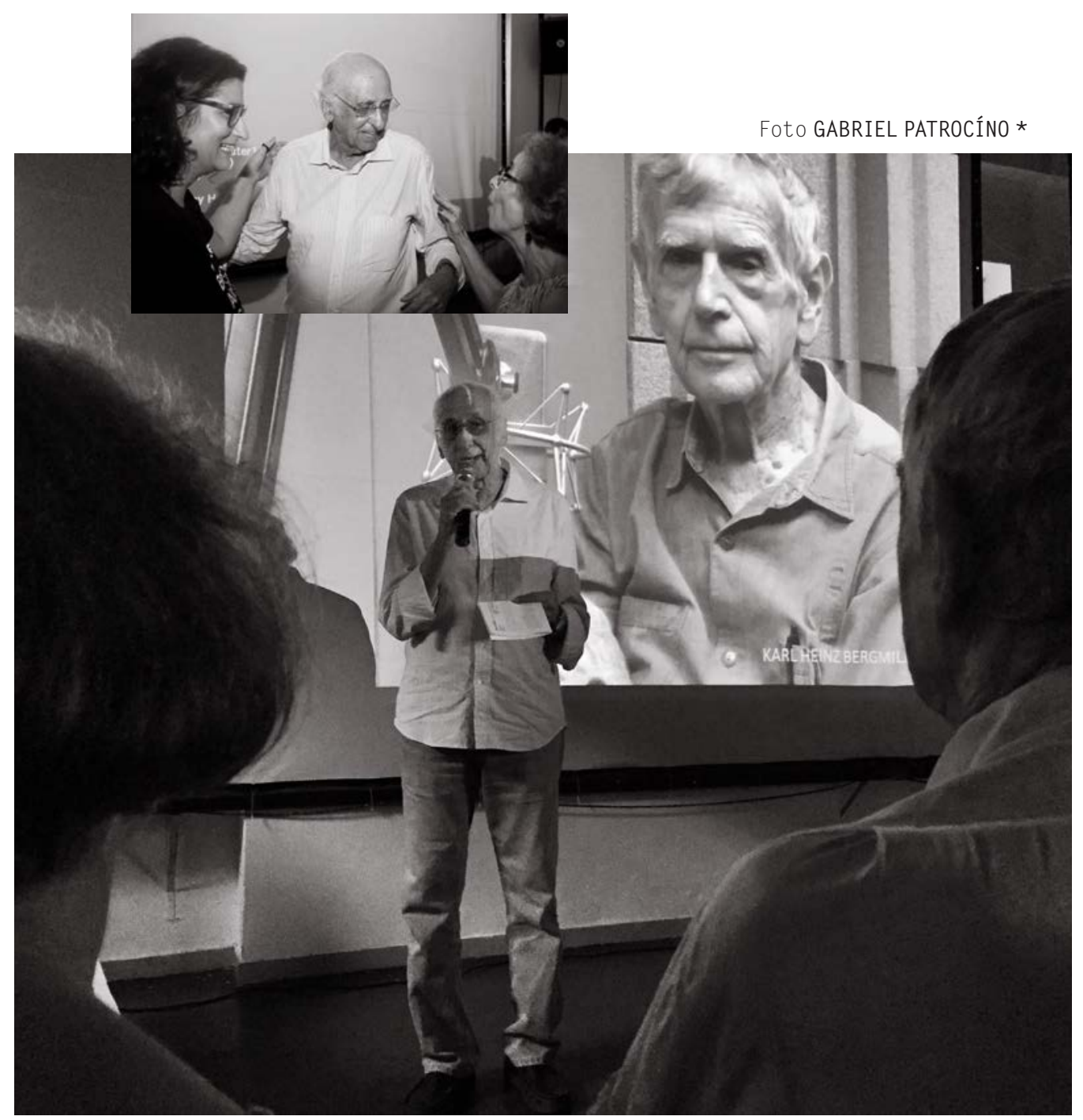

Zuenir Ventura conversa sobre a crise no ensino público e seus reflexos na sociedade, no evento ESDI非ABERTA. No dia anterior, 11 de fevereiro ele manifestou publicamente seu desconfor to em sua coluna em 0 GLOBO.

* Foto projetada no telão cedida por Izabela Perrota 

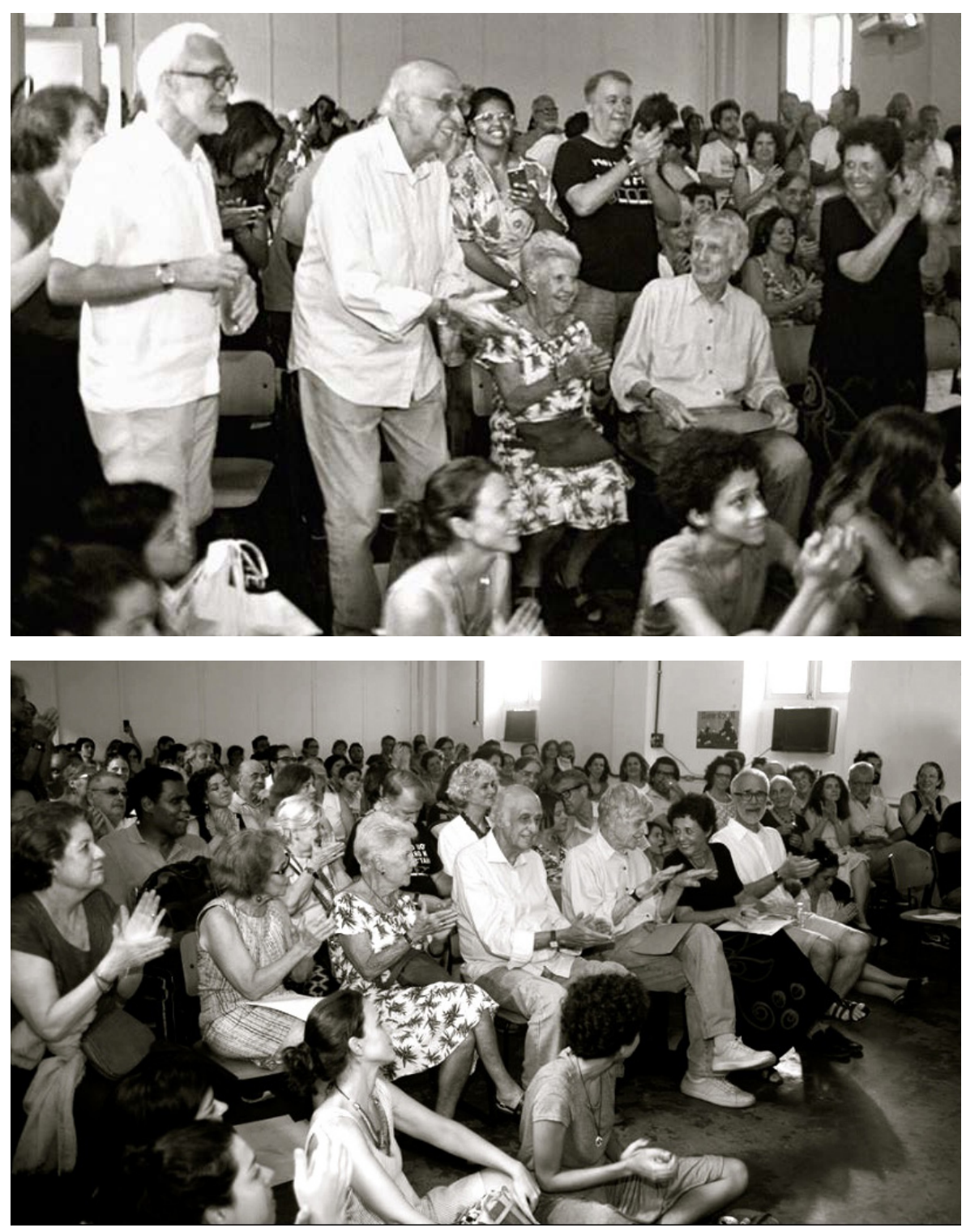

Em pé da esquerda para a direita Washington Lessa e Zuenir Ventura Sentados Teresa Miranda e Karl Heinz Bergmiller, ao seu lado Bitiz, atrás Gabriel Patrocínio

Marcos Martins e Zoy Anastassakis vice-diretor e diretora da ESDI $=>$

Bitiz Afflalo, apresenta Bergmiller às novas gerações. Na primeira fila Samara Tanaka da equipe de organização do evento. Atrás de Marcos e Zoy, os professores Elianne Jobim, Fernando Reiszel e Denise Del Re Filippo $\Rightarrow$

Na plateia Bergmiller entre amigos, alunos, ex-alunos e professores de várias gerações. A esquerda Suzana Valladares 
Bergmiller em uma conversa bem humorada com os esdianos comenta sobre o significado de receber uma homenagem. Ao mesmo tempo faz um depoimento muito firme: Este evento é "um ato de resistência”.

No chão à esquerda prof. Mauro Pinheiro ESDI非ABERTA fotos PHILIPPE LEON

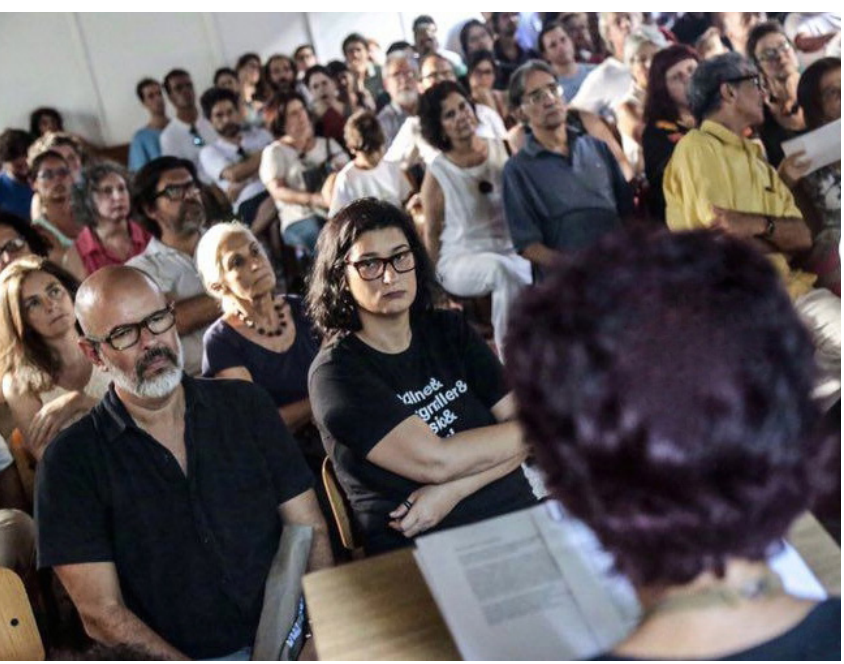

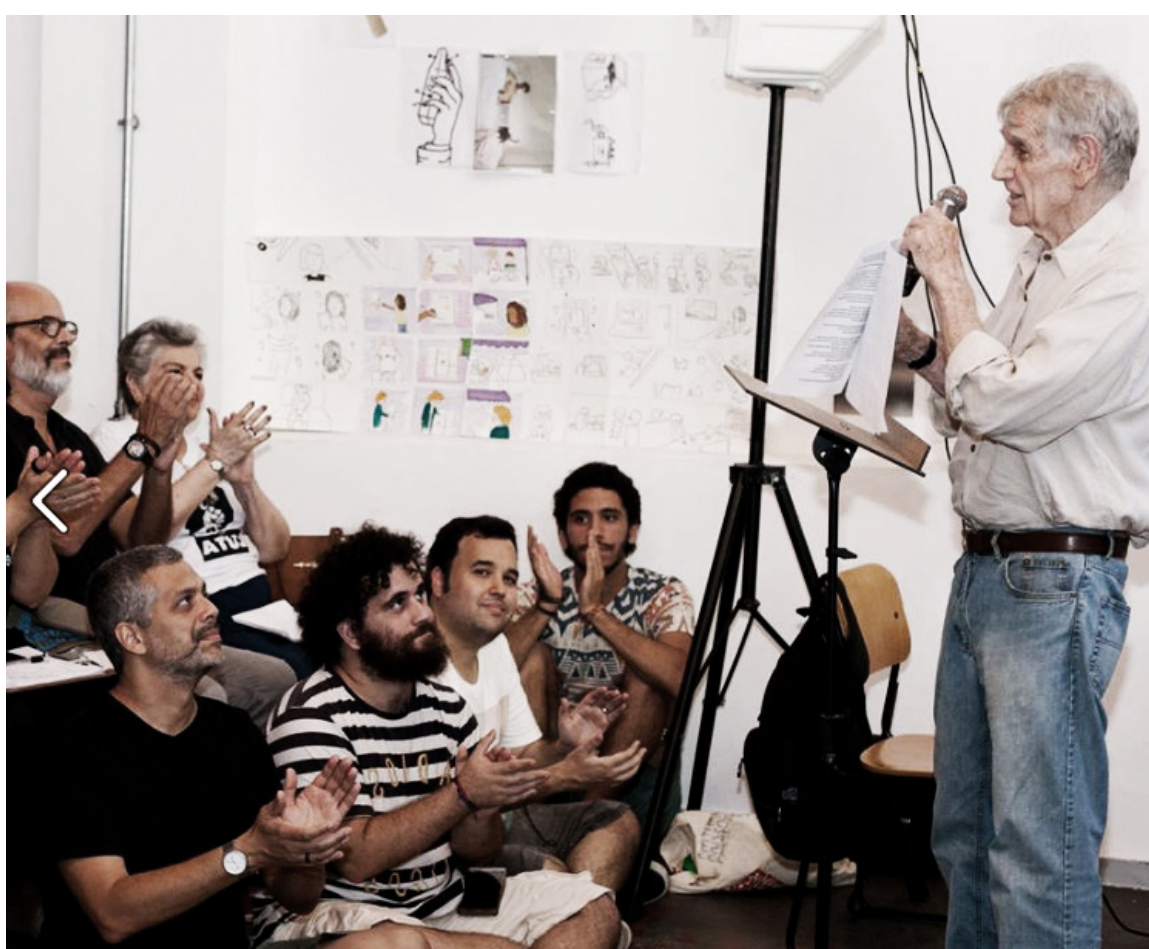

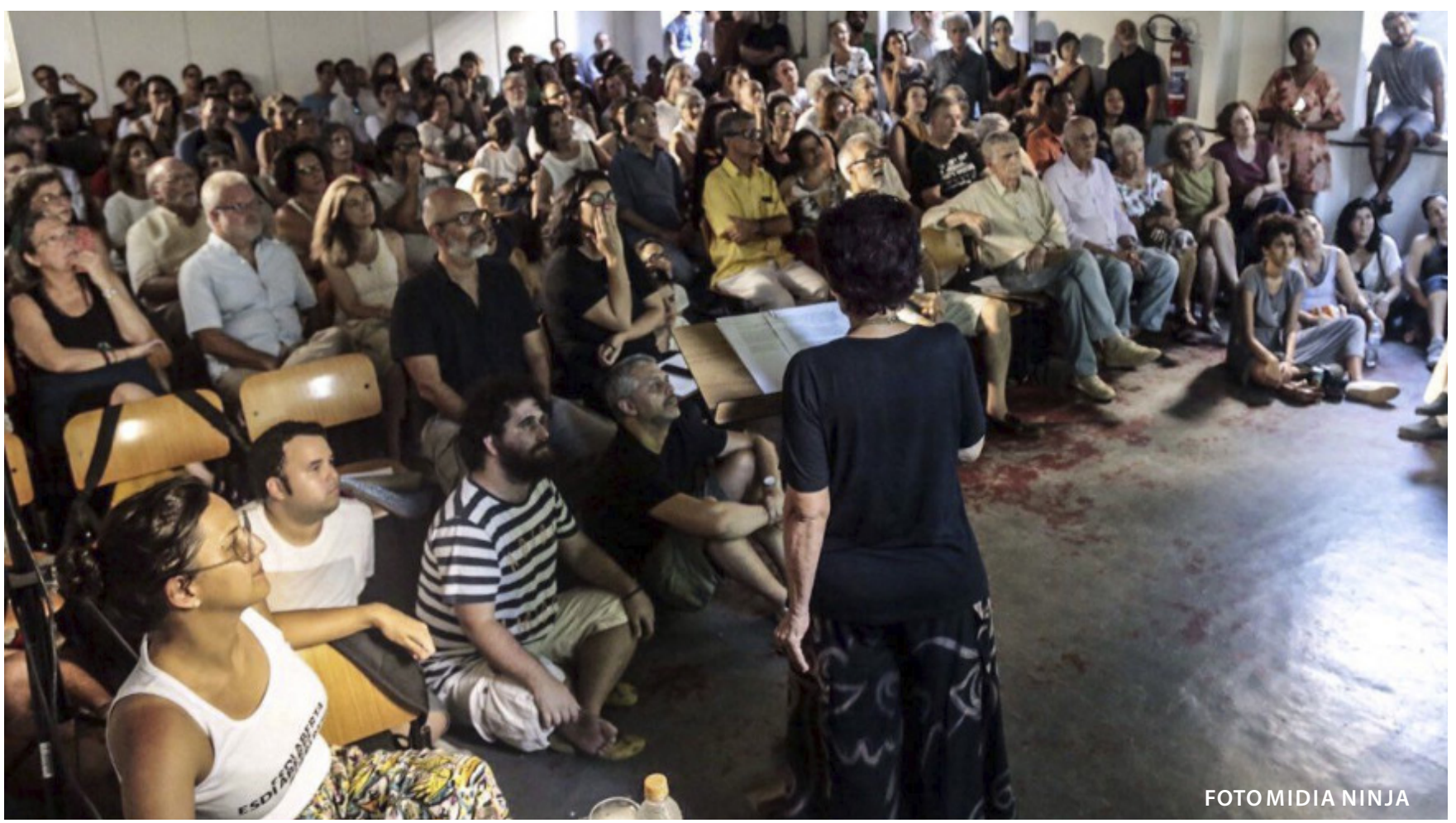




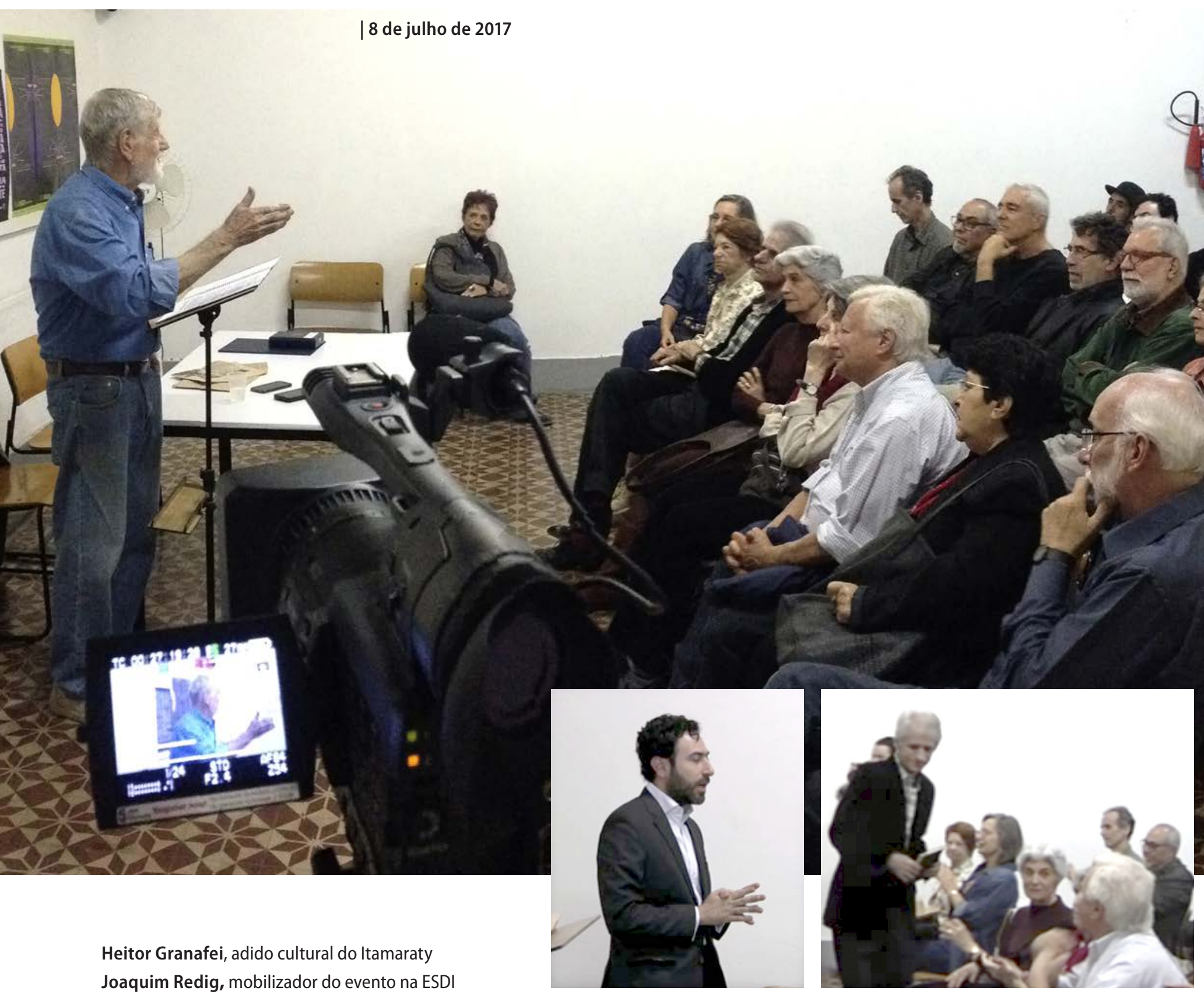

CONVITE

AexDI Associação dos ex-Alunos da ESDI Escola Superior de Desenho Industrial convida para o encontro

APRENDIZES de BERGMILLER.

Conversa com o designer e professor Karl Heinz Bergmiller, fundador da ESDI e do design brasileiro, dia 8 de julho de 2017 às $16 \mathrm{~h}$ na Escola. Entrega da condecoração da Ordem do Rio Branco a ele concedida pelo Itamaraty em março passado. 


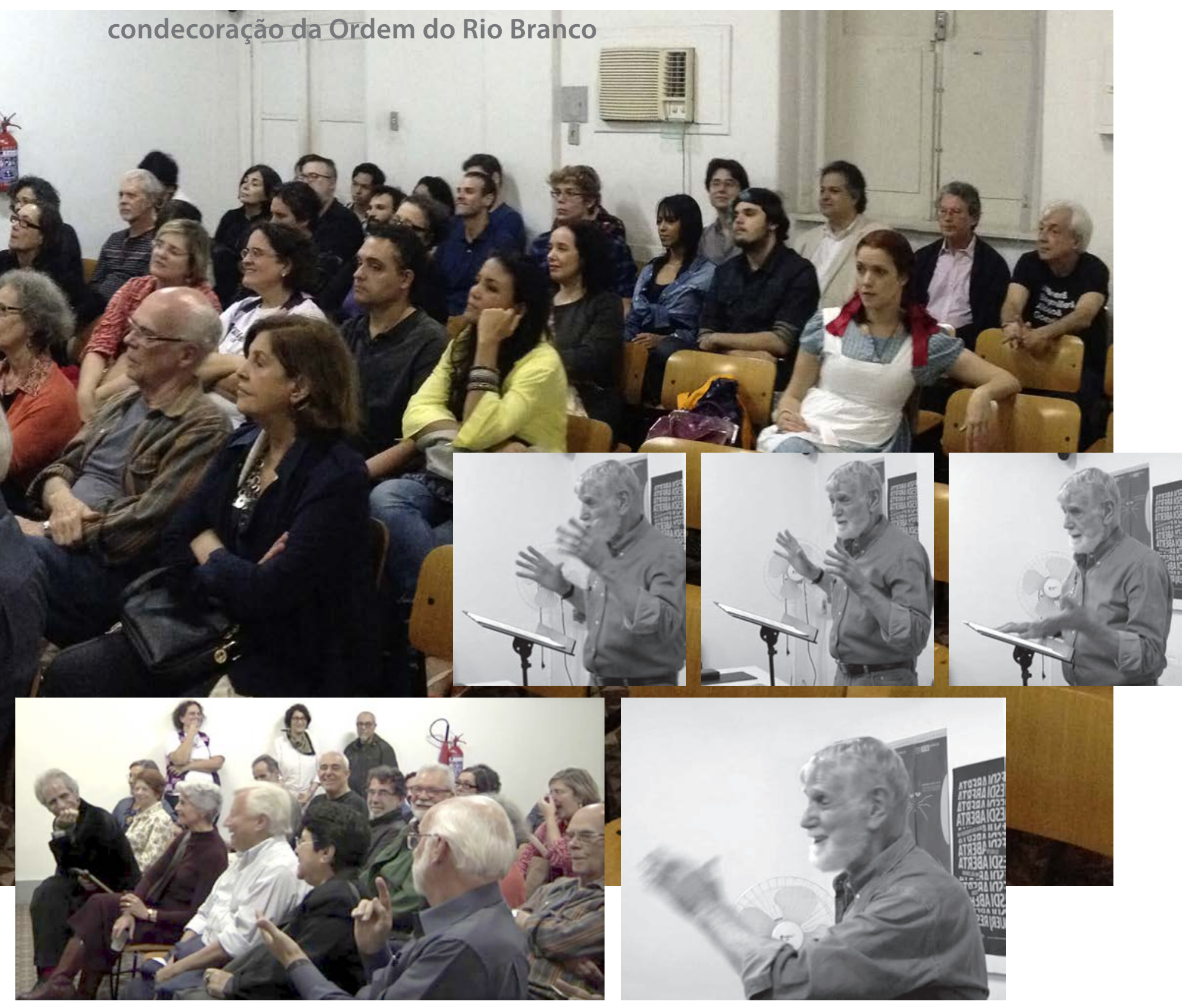

Na platéia, na primeira fila da esquerda para a direita Cerinha,

Ceres Feijó, Joaquim Redig, Ana Luiza Escorel, Deda (Maria Valderez),

Roberto e Marta Verschleisser e Freddy van Camp. Atrás dele Moema, ex-

bibliotecária da ESDI. Gláucio Campelo, Arisio Rabin, Celso Santos,

João Leite, Rodolfo Capeto, e Thaís Vieira, organizadora do evento.

Foto e imagens de vídeo ALMIR MIRABEAU 
Bergmiller recebe a condecoração da Ordem do Rio Branco no encontro APRENDIZES de BERGMILLER organizado por Joaquim Redig.

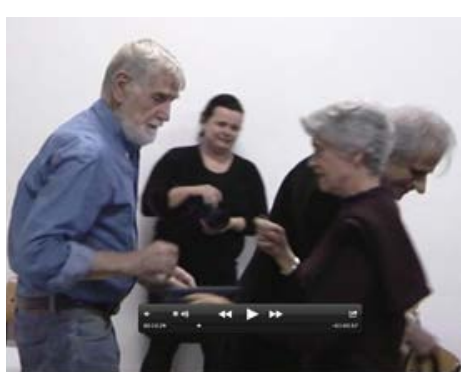

Ana Luiza Escorel e Joaquim Redig entregam a medalha Barão do Rio Branco a Karl Heinz Bergmiller.

\section{de ULM ao RIO}

Recebendo medalhas "o coração mexe", mas eu fico muito mais comovido com a presença de vocês. 0 amigo Joaquim Redig me mandou uma lista com 10 perguntas todas pertinentes, a maioria ligadas a ESDI, temas que podiam servir de base, para um debate mais amplo, num encontro como esse.

Sempre defendi a ideia da "discussão permanente" dos métodos de ensino, especialmente do ensino de design que requer uma dinâmica toda especial. Para mim seria interessante ver as etapas da evolução da ESDI dos anos 60 pra cá, da época da sua fundação e afirmação, até os tempos atuais. Considerando que a Bauhaus e Ulm sobreviveram somente 14 anos cada uma, a nossa escola tem uma estória mais longa para levantar dados e depois analisar.

Devo citar daqui em diante varias vezes Ulm. Quem não sabe, o que significa Ulm, vou esclarecer rapidamente: UI é uma pequena cidade medieval no sul da Alemanha à beira do Danúbio; a torre da catedral gótica de Ulm é a mais alta de todas catedrais góticas; em Ulm nasceu Albert Einstein; em Ulm nasceu a Hochschule für Gestaltung, seguidora da Bauhaus.

Eu me formei em Ulm, Wollner e Decurtins se formaram em Ulm. As raízes da ESDI, só procurando em Ulm... A Hochschule für Gestaltung de Ulm não funciona mais, mas a torre gótica de Ulm esta firme como sempre. ESDlanos, vão pra Ulm, vasculhar pelos seus antecedentes!
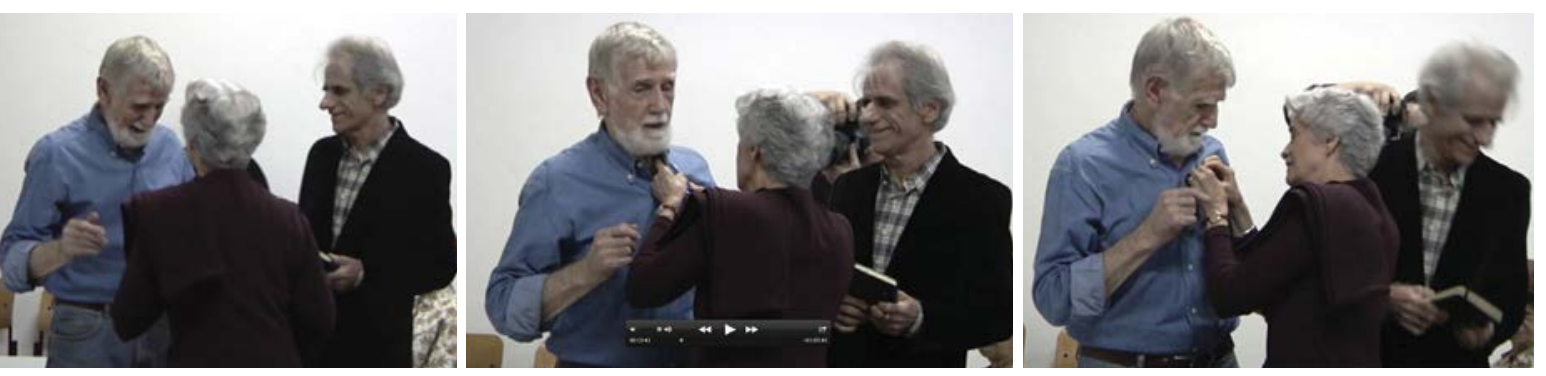

Prefiro conversar em vez de responder aos 10 itens de Joaquim Redig. Vou responder por enquanto a pergunta numero nove: "Como é e o que representa para você ser designer e professor no Brasil e como você imaginaria sua vida na Alemanha, se você não tivesse vindo pra cá?

Joaquim, por favor, não quero imaginar isto - estou feliz aqui !

Preparei para este encontro um depoimento mais no clima "Cinquentenário do palácio Itamaraty" que resultou em medalhas e honrarias. O lugar certo para comemorar só podia ser aqui na ESDI, onde tudo começou!

"Só existe design num país onde existe consciência de ensinar design" Palavras de Tomás Maldonado, mil anos atrás, felicitando pela criação da ESDI. 
um passeio memorável pela Avenida Rio Branco

Foi no dia 19 de dezembro de 1958 - o dia em que eu cheguei ao Brasil. Direto de Ulm, mas via marítima a partir de Génova com destino pra Santos, onde o Alexandre Wollner me aguardava mas o Conte Grande gentilmente deu uma paradinha no porto do Rio de Janeiro e eu aproveitei para dar um pulo pra fora.

Fantástico, do porto do Rio de Janeiro, com alguns passos, e você se encontra no Centro da cidade. Eu já tinha um monte de informações sobre o Brasil: dos movimentos artísticos, da arquitetura moderna, do planejamento de uma nova capital e das indústrias em plena evolução, todo mundo enxergava um futuro promissor. Gerava um alto astral nessa época, nesse pais. Mas eu não cheguei como um deslumbrado e nem com espírito de turista, cheguei com uma bolsa de estudos do governo brasileiro. Bolsa de estudos para quê ? E qual é seu interesse pelo Brasil ? São questões que eu pretendo esclarecer antes, durante e depois daquele "passeio memorável" pela avenida Rio Branco.

O número de brasileiros que estudaram em Ulm era algo surpreendente. Logo no início estiveram lá: Mary Viera, Almir Mavignier, Alexandre Wollner, Frauke e Elke Koch Weser e Yedda Pitanguy. Era um grupo com muito interessado nos estudos e acima de tudo muito querido dentro da "comunidade UIm". Eu estava sempre enturmado com os brasileiros.
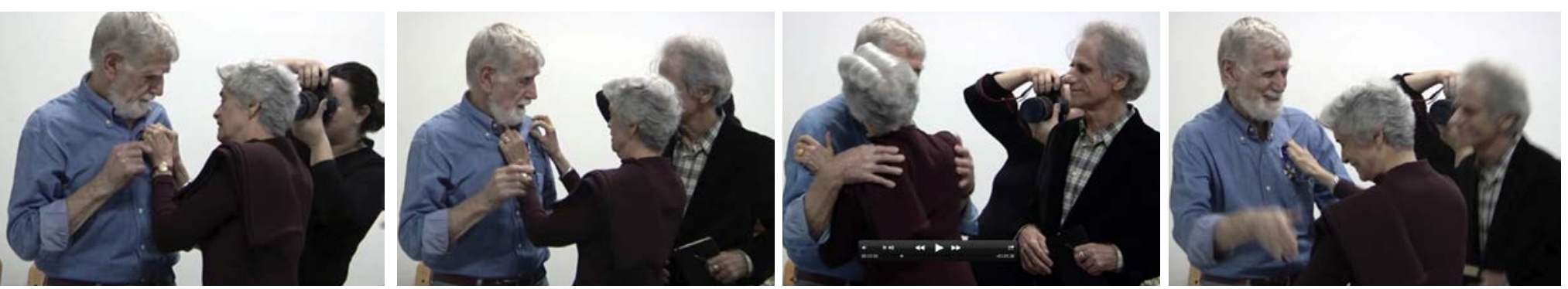

O interesse dos Brasileiros por Ulm tem sua origem na presença de Max Bill no Brasil no início dos anos cinquenta. Max Bill ganhou o grande prêmio na I Bienal de São Paulo, fez uma "exposição histórica no MASP", realizou entrevistas e conferências em São Paulo e no Rio de Janeiro e justamente na mesma época ele estava empenhado no planejamento da escola de Ulm, a Hhochschule für Gestaltung. Por curiosidade, antes da sua inauguração, essa escola ganhou prestígio no Brasil. Agora vem o inverso - um alemão da escola de Ulm tem interesse pelo Brasil. A embaixada brasileira na Alemanha solicitou ao meu colega Alexandre Wollner de indicar candidatos para uma eventual bolsa de estudos no Brasil. Alexandre Wollner me perguntou: "Hast du Interesse nach Brasilien zu kommen ?"

\section{— Que dúvida — Brasil era considerado o país do futuro.}


Assim, com as recomendações de Max Bill, um alemão da escola de Ulm, armado com uma bolsa de estudos, botou os pés em terra firme, no Rio de Janeiro. Andei com passos acelerados como alguém que já conhece a cidade. Estudei antes no navio o mapa do Rio de Janeiro. Meu programa era de ver o estágio das obras do Museu de Arte Moderna, que fica depois da avenida Rio Branco e também por essas áreas eu pretendia visitar o Ministério de Educação e Cultura, ambas eram obras que despertaram meu interesse durante os estudos em Ulm.

No caminho, entrei num bar, querendo telefonar para Yedda Pitanguy, que tinha voltada de UIm um pouco antes de mim, mas a Yedda não estava em casa, falei com a mãe dela. Primeiro papo, primeira experiência: o telefone demorou dar linha, (nestes 50 anos, nada evoluiu tanto no país como o sistema de telecomunicação!) Querem saber onde a Yedda Pitanguy morava ? Na rua do Russel, no mesmo edifício do Pedro e da Silvia! Agora podem me dizer: onde vocês dois andaram ?

Atravessei agitado a praça Mauá e me encontrei no inicio da avenida Rio Branco. O dia estava lindo, os edifícios refletiram um tipo de luminosidade, uma sensação que ficou gravada pra sempre. A avenida Rio Branco nesse momento, parecia para mim "um corredor glorioso para entrar no Brasil". Cruzei a Presidente Vargas, só vi de passagem a Candelária, eu não tinha tempo e não estava a fim para ver igrejas ou monumentos, eu queria sentir mais a dinâmica da cidade.

O trânsito, não estou me lembrando se a avenida Rio Branco tinha mão única ou mão dupla, também não observei bem o que circulava e buzinava tanto, guardei só aquela sensação: Uma multidão de carros pretos em movimento, alguns Fuscas no meio, claro era o início da montadora Volkswagen em São Paulo. Falando mais em detalhes, seria mera fantasia, porque carros nunca fizeram parte das minhas paixões.

Eu que acabei de chegar da Alemanha, saindo do pleno inverno de lá, pálido, me senti nos trópicos um esquisitão, notei uma população andando por ali, mais pra morena, morena em várias escalas, me consolei, em breve eu também vou pegar um pouco dessa tonalidade saudável.

Não me lembro de ter visto miséria ou sujeira, porque o Almir Mavignier, um carioca, colega em Ulm, me preveniu: "tu vai ver muita pobreza no Brasil". Mas a avenida Rio Branco nessa época gente, era o bulevar mais nobre do país .
Andando pela avenida Rio Branco, pulei às vezes para a outra calçada, passei pelo Teatro Municipal, consultando o guia: no outro lado a Biblioteca Nacional, e a Escola de Belas Artes, agitado, quase tropecei, olhando para o Palácio Monroe, coisa chocante, chocante para qualquer ulmiano, bauhausiano, esdiano. Fugi de lá e no outro lado da avenida Rio Branco, entrei numa travessa e mais adiante encontrei, aliviado como um bravo romeiro o que eu estava mesmo procurando: o Ministério da Educação e Cultura.

Esta obra chamou muita atenção na Europa, sempre com crédito do arquiteto franco/suíço Le Corbusier, considerado "o maior". Le Corbusier foi convidado pelo então ministro Gustavo Capanema, recomendado por Lúcio Costa. Le Corbusier aceitou o convite e chegou como consultor, a meu ver como "consultor mestre", 80 anos atrás.

Curioso, antes da vinda de Le Corbusier foi realizado um concurso de arquitetura até premiado um projeto, mas o próprio ministro ignorou o resultado e com o apoio de Lúcio Costa foram redefinidos os critérios para a construção do novo MEC. Foi uma decisão lucida, faz parte da histórica da arquitetura e da cultura do país.

Antes da Segunda Guerra Mundial teve início a construção do MEC, que foi concluído logo depois daquele conflito que resultou numa devastação em vários países. Depois os Europeus perceberem que existia ainda outro lugar neste mundo, onde pessoas lutaram, mas lutaram para defender conceitos e construíram algo revolucionário, aqui no Rio de Janeiro: o Ministério da Educação e Cultura! Quem elaborou o projeto foi uma equipe de arquitetos brasileiros, todos jovens ainda, coordenada pelo nosso grande arquiteto urbanista Lúcio Costa.

Com essa obra, o MEC marcou o iniciou da arquitetura moderna no Brasil. Além disso, esta obra representa "algo especial", o esforço de uma equipe. Interessante nessa historia, todos daquela turma que o Lúcio Costa selecionou, todos se tornaram famosos: Oscar Niemeyer, Affonso Eduardo Reidy, Jorge Moreira, Ernani Vasconcellos, Carlos Leão.

Um lugar destinado a administração e orientação das questões da educação e da cultura, deve ser coerente, deve expressar na própria edificação seu conceito. Acredito que esses foram alguns parâmetros para o projeto.

Vou dar um pulo no tempo. Eu acho que o projeto para o Ministério de Educação e Cultura deve ter servido como exemplo para do Palácio Itamaraty em Brasília, em relação à integração harmônica entre arquitetura e obras de arte. Tudo no seu devido tempo. São Ministérios com funções bem distintas. 
O Palácio Itamaraty é o palco principal para encontros e decisões internacionais, o caráter da representatividade é a finalidade um. As obras de arte não devem ser consideradas como decoração, são integrantes na concepção arquitetônica. Max Bill definiu uma vez suas criações como "objetos de uso psicológico". Para apreciar o MEC essa obra inovadora, eu precisava ter tempo, deixei isso para uma outra visita ao Rio de Janeiro.

Voltei para avenida Rio Branco, já dava para ver e sentir a baía da Guanabara onde termina a avenida Rio Branco. Maravilha, uma avenida começa perto do porto, segue reto $2 \mathrm{~km}$ e termina novamente perto do mar.

Eu que nasci nos Alpes da Baviera, eu tinha sempre um fascínio por cidades perto do mar. Achava que as pessoas que vivem lá, deviam ter ideias misteriosas, desejos que vão além dos horizontes. Considerava Hamburgo sempre uma cidade mais atenta pra fora, do que para a Alemanha, muito mais interessada em estabelecer laços com outros continentes.

Perto da beira-mar, eu me vejo ainda dando um ahhh vendo o Pão de Açúcar, Zuckerhut chapéu de açúcar em alemão; Pão de Açúcar é mais apropriado.

Pensei: um dia vou dar uma de turista, vou subir de bondinho, vou soltar um outro ahhh vendo o Rio de Janeiro inteiro com seus morros florestas praias, lagoas! Chega de ser romântico, seu babaca, falei para mim mesmo, acabaste de chegar de Ulm. Me recompus.

Finalmente, o que eu aguardei, ansiosamente: só virando um pouco para esquerda lá estava, novinho em folha, o Museu de Arte Moderna, na sua primeira fase da construção: o "bloco escola" inaugurado um pouco antes da minha chegada.

Conheci o MAM em fotos de maquetes e conheci as propostas desse museu. A Niomar Sodré, diretora e fundadora do Museu de Arte Moderna esteve uma vez em Ulm, e se entusiasmou pela Hochschule für Gestaltung e proclamaou:

"vou fazer a mesma escola no meu museu!"

O manifesto da Niomar deve ser incluído nos anais da história do design do Brasil!

$\mathrm{O}$ arquiteto Affonso Eduardo Reidy adaptou o projeto do MAM para essa finalidade e Tomás Maldonado começou a elaborar o programa — "aquele"!

Eu observei o museu de arte moderna a distância, respeitosamente. Maldonado tinha feito para mim uma carta de apresentação, mas neste momento, a carta não estava comigo e também não era a hora de ir lá e dizer:

"acabei de chegar de Ulm"
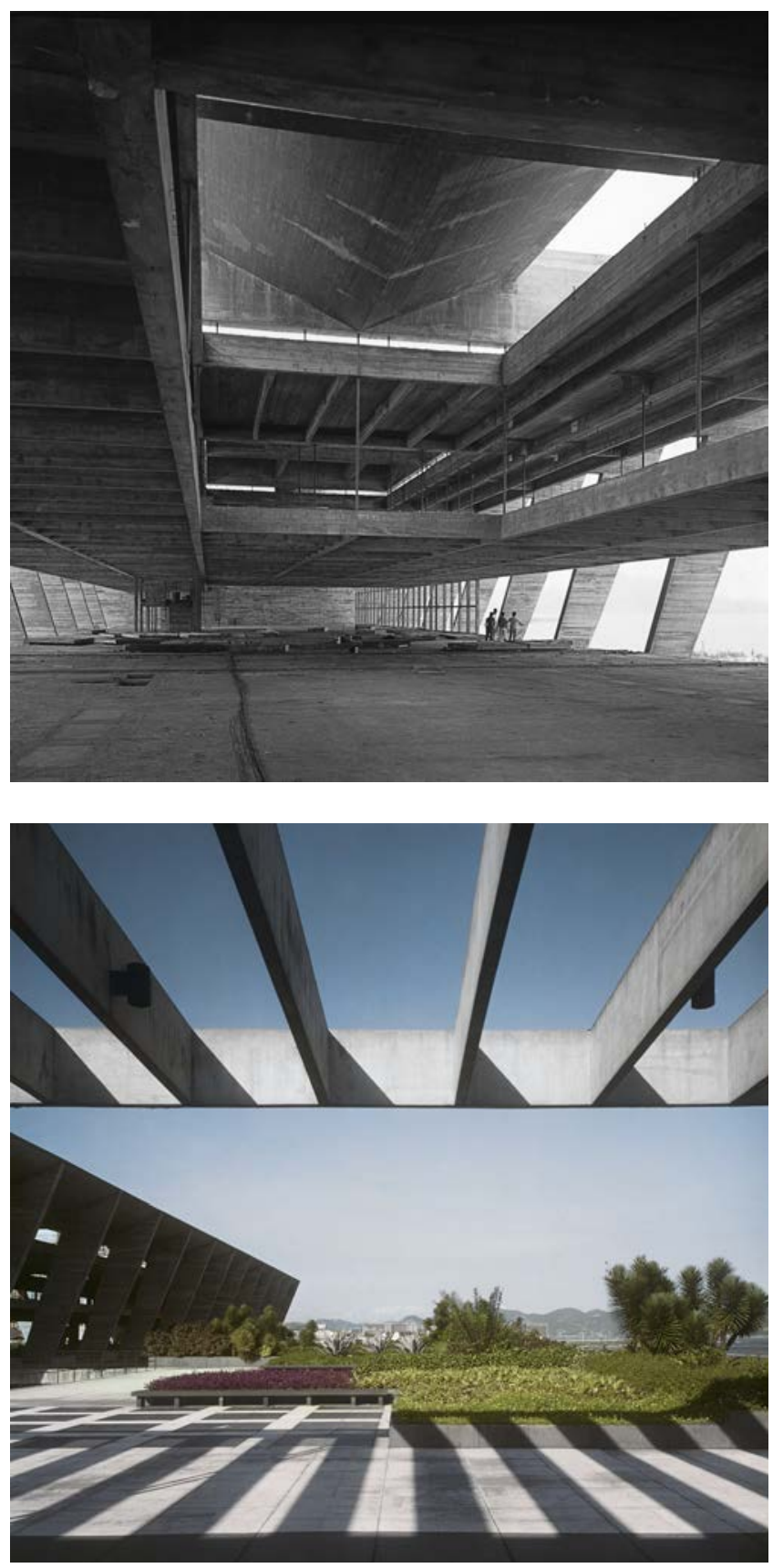

| 1964 | 1968

Museu de Arte Moderna do Rio de Janeiro Fotos MARCEL GAUTHEROT, Arquivo ESDI Restauração de imagem, Cesar Barreto 


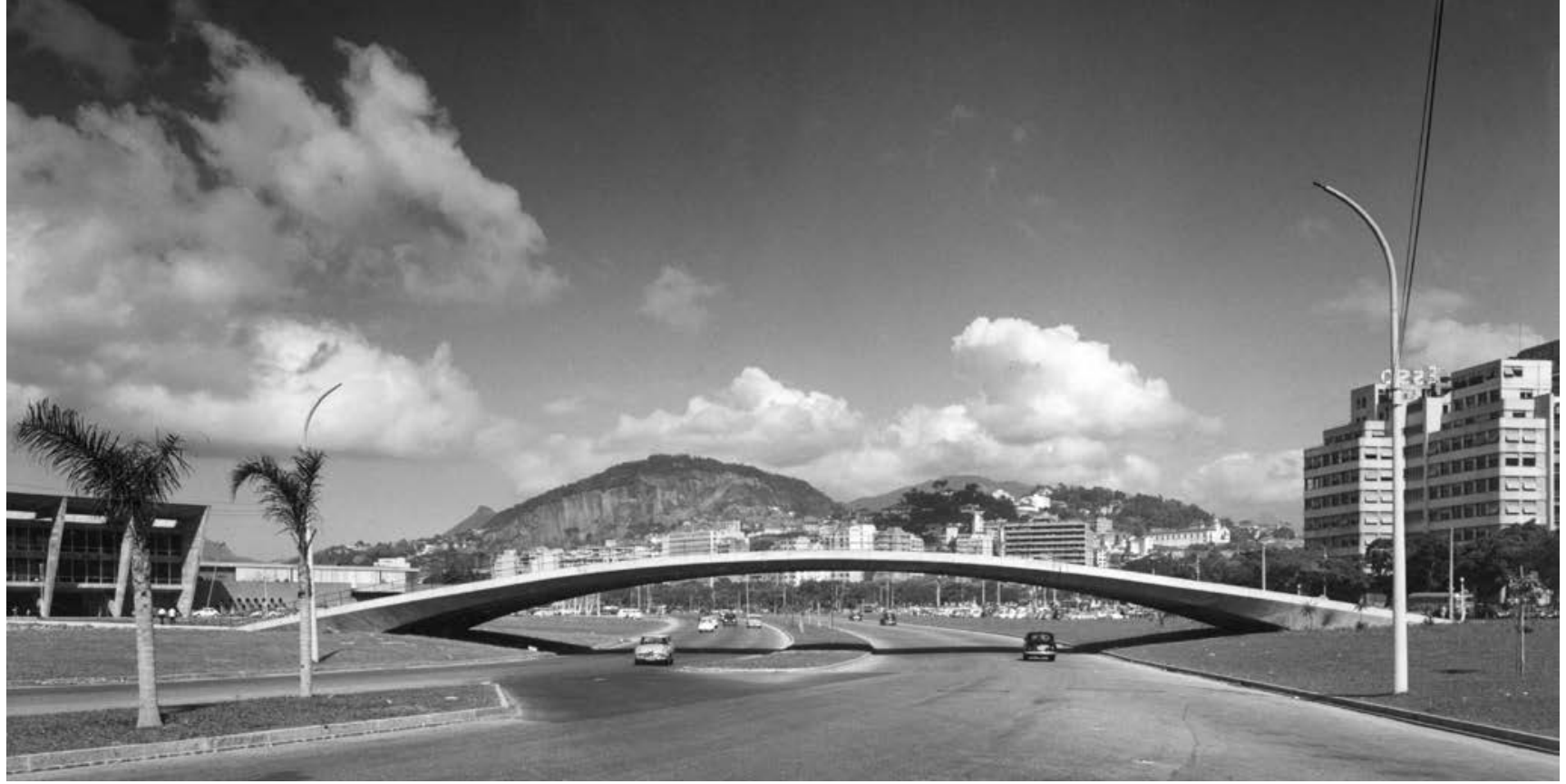

Passarela projetada por Afonso Eduardo Reidy, Parque do Flamengo em frente ao MAM. Foto MARCEL GAUTHEROT, Arquivo ESDI

Bom, agora voltando para a avenida Rio Branco e também de volta ao presente. Eu, jamais podia imaginar, eu no primeiro dia no Brasil, olhando para o Museu de Arte Moderna nesse cenário deslumbrante, lá vou desenvolver o que eu aprendi em Ulm.

Também não podia sonhar neste momento, eu vou organizar um dia uma exposição de design, justamente no Ministério de Educação Cultura, que eu acabei de admirar, mas isso virou realidade, trinta anos depois. 0 evento chamou-se "Escritório, forma e função no final do século XX". Os esdianos Goebel, Pedro, Bitiz, Zuenir, Lauro fizerem parte desse projeto. Mais ainda, durante a montagem entrou o velho Lúcio Costa, examinando se o salão estava em ordem e se o "azul" da parede no fundo, correspondia ainda ao projeto original. Não estou delirando - foi o Lúcio Costa em pessoa!

No final, eu, que acabei de chegar de Ulm, não podia fantasiar de receber um dia uma medalha com o mesmo sobrenome da avenida: "Rio Branco". Me pegou de surpresa.

No ano passado um jovem diplomata do Itamaraty Heitor Granafei, me telefonou, dizendo que estava organizando os festejos para os 50 anos do Palácio Itamaraty. Como ele encontrou desenhos e documentos com meu nome, marcamos um encontro para esclarecer detalhes. Sim, eu projetei móveis de escritório para o anexo do Palácio Itamaraty, solicitados pelo embaixador Wladimir Murtinho. Depois de uma concorrência e a apresentação dos protótipos, uma fábrica ganhou e forneceu os móveis. $O$ diplomata Heitor Granafei comentou: muitos desses móveis se encontram ainda em uso! Fiquei satisfeito porque um dos requisitos básicos para mim era sempre a qualidade técnica do produto.
Também me lembrei, além do projeto para esses móveis, eu tinha outros contatos com o Itamaraty e quase sempre através do embaixador Wladimir Murtinho. As Bienais Internacionais de Design 1968, 1970 e 1972 realizadas no MAM; alertei que a ideia partiu do MRE de realizar alternadamente com a Bienal de São Paulo a Bienal Internacional de Desenho Industrial do Rio de Janeiro. Foi uma época, caracterizada pelos esforços de implantar no Brasil uma "nova atividade e nova mentalidade, voltada para o design".

Mostrei uma pasta com documentos para o conselheiro Heitor Granafei e comentei o Itamaraty sempre foi um Ministério de Vanguarda, inclusive minha bolsa de estudos vinha de lá ! Relatei ainda sobre uma exposição patrocinada pelo Itamaraty e divulgada com toda pompa - "Arte Tradicional da Costa do Marfim", 1973. Para a abertura da mostra aguardou-se no Rio uma delegação numerosa de Brasília, mas nós no Museu, já num clima de angústia ficamos na espera pelas obras africanas ...Chegaram em cima da hora.

Felizmente o MAM tinha um sistema de exposições e uma metodologia de processar eventos. Somente com a listagem das obras na mão, o salão foi organizado e equipado. Assim que as obras saíram do container, foram imediatamente penduradas nos painéis, colocadas em cima dos pedestais e nas vitrines. Tudo estava previamente identificadado, até iluminado. Me lembro que na inauguração ainda podia sentir, no salão do Museu de Arte Moderna "o aroma da África".

A mostra foi um sucesso e depois montada no Palácio Itamaraty em Brasília. O embaixador Wladimir Murtinho comentou: "só nós no Brasil sabemos fazer isto". 
Esse argumento marcou, mas nunca confundi as palavras do embaixador com aquela frase: "no Brasil, no final, tudo vai dar certo". Eu tinha a maior estima pelo embaixador Wladimir Murtinho, ele era um homem culto, cheio de otimismo, dinâmico, mas também realista. 0 que eu apreciei nele foi o seu 0 senso de humor .

Só nos no Brasil sabemos fazer isto! Não estava brincando! Foi a definição de um diplomata com longa vivência e conhecimento dos métodos do mundo afora, mas também provou no seu país, seu grande talento na coordenação da mudança do Ministério das Relações Exteriores no Rio de Janeiro para Brasília e sua instalação no Palácio Itamaraty. Com um resultado magnífico!

O Brasil é um pais dinâmico. Esse comentário eu soltei muitos anos atrás na ESDI, porque no Brasil certas decisões são tomadas num outro ritmo do que "lá fora". Muitas vezes por falta de tempo, mas também por falta de subsídios, não se tem condições de planejar com a devida profundidade, pulam-se etapas, típico de países novos, de países em desenvolvimento.

Não gostaria de generalizar, menos ainda de ofender os bravos cientistas, pesquisadores fanáticos que acreditam e defendem suas ideias e invenções movidos em geral por puro idealismo, são verdadeiros santos neste país. Tenho maior respeito e admiração por eles.

Eu não sou artista, eu não sou um cientista, eu não sou um fanático, não me considero um santo. Idealista, sim. Podem me chamar de designer idealista.

Aliás, hoje, reunidos aqui na ESDI, eu só vejo idealistas que, apesar da situação vergonhosa do Estado, jamais vão abandonar as suas convicções. Não vou desenvolver este tema que aflige a todos. Vou continuar meu depoimento sem lamentações.

Eu percebi e entendi que no Brasil "tempo/prazo" têm um outro significado. Aprendi no Brasil a adotar para meu trabalho uma escala de valores diferenciada sem perder de vista os objetivos para o futuro. Aprendi a enfrentar tarefas com a devida agilidade e tolerância. Aprendi a apelar em certos momentos para o bom senso. Aprendi no Brasil algo que é fundamental: "a pressa é um risco - mas a demora é um outro risco".

Assim eu interpreto a frase do embaixador Wladimir Murtinho que surpreendeu a gente quarenta e quatro anos atrás: "só nós no Brasil sabemos fazer isto". Um conceito aliás, que pode ser de tempos em tempos reavaliado.

Pouco tempo atrás, num jantar simpático, na casa da amiga Ceres Feijó, o amigo Zuenir Ventura sentado na minha frente, me perguntou: "Bergmiller, qual foi seu trabalho mais importante no Brasil, foi na ESDI ? Não foi, respondi na hora e apontei para um outro feito. Aliás a amiga Ceres está presente, para quem não a conhece: é a juíza Ceres Feijó que fez parte da equipe na estruturação da ESDI, é a origem da nossa amizade, uma amizade de 55 anos. A ESDI criou grandes designers e grandes amizades!

Voltando à pergunta de Zuenir: pensei melhor, inclusive com microfone na mão: "o que eu acho, o que foi mais importante para mim". Atuei nas indústrias, no ensino, em pesquisas, em instituições culturais. Acho, não tem primeiro, segundo terceiro quarto - todos tinham o mesmo peso.

\section{na indústria}

Meu interesse como industrial designer era sempre a sistematização. Isso significa desenvolver programas de produtos e não objetos isolados. A sistematização resulta numa racionalização dos processos fabris, no estoque no transporte, na manutenção e na comercialização. Uma política empresarial que segue os princípios da sistematização de forma consequente, pode fabricar um número reduzido de componentes/ intercambiáveis, que possibilitam compor produtos em muitas versões, teoricamente sem limite. Mas, para ter sucesso na indústria era fundamental a sintonia total entre os desejos dos empresários e minhas propostas.

\section{no ensino}

Participei ativamente na ESDI até 1998. Depois acompanhei a evolução da escola através de colegas, amigos, ex-alunos. É evidente que toda a minha vida profissional tem suas raízes aqui. Aliás, as árvores em volta da escola, eu vi plantar, eu ainda me identifico com elas.

Hoje não pretendo relatar detalhes sobre minha participação na ESDI, histórias que pertencem ao "século passado", talvez volte numa outra ocasião e de forma mais especifica. Hoje quero soltar só algumas ideias, para pensar depois.

A evolução tecnológica provocou sempre mudanças na sociedade de consumo. Mas a instabilidade politico-econômica dos últimos tempos ficou tão evidente no Brasil, que resultou em novas estratégias empresariais, com cortes na área de investimentos, principalmente no desenvolvimento e oferta de novos produtos."

É mais fácil e mais barato importar da China — ouvi falar isso muitas vezes. Esses argumentos refletem diretamente para nas perspectivas profissionais, entre outras para os futuros designers. Adaptar-se simplesmente à conjuntura atual? Confesso minha total antipatia! Mas questionar e revisar os 
métodos de ensino, sem abandonar princípios éticos enraizados nesta escola? Estou abraçando!

Manter uma discussão ampla, viva, permanente sobre os métodos da formação do designer, mas não somente entre nós esdlanos. Convidar personalidades fora do âmbito acadêmico para ouvir e discutir temas como: tecnologia, economia, sociologia, psicologia, ciências políticas, manifestações artísticas etc. etc.

Em 1972 esteve na ESDI, nesta sala, o Pierre Cardin, o mais famoso estilista de moda de todos os tempos, discutindo com os alunos da ESDI. Aqui está a páginado JB - "Objetos põem em campos opostos Pierre Cardin e alunos da ESDI". Fico pasmo ainda, da reação dos alunos, Pierre Cardin meteu-se no nosso negócio? Porém o encontro foi positivo, porque provocou posturas, afirmou conceitos.

O que nunca deve mudar na ESDI, é o objetivo de treinar um tipo de profissional que saiba um dia com segurança e responsabilidade ética social, conquistar seu espaço de trabalho. A ESDI tem por obrigação histórica manter-se na vanguarda do ensino de design no Brasil. Estou ciente da minha falação. Não estou ignorando a nossa "situação delicada, cheia de incertezas". Mas a ESDI não se encontra em estado de abandono, as evidências são visíveis num evento como este, hoje 8 de julho de 2017. Por favor considerem todas as minhas observações como de um idealista insanável !

\section{nas pesquisas}

Qualquer projeto de design começa com um levantamento e análise de dados, para definir com precisão, o problema e estabelecer os parâmetros projetuais. Não vou chamar isso de pesquisa; é um método para evitar soluções espontâneas. 0 IDI assumiu projetos complexos, formando até equipes interdisciplinares. Em geral eram solicitações de entidades públicas como por exemplo:

O Ministério da Indústria e do Comércio solicitou ao IDI uma pesquisa que orientasse as empresas exportadoras sobre os critérios das embalagens dos seus produtos. A finalidade do MIC era óbvia: conquistar o mercado externo, alcançar a confiança pelo produto brasileiro já a partir da sua apresentação na embalagem.

O projeto resultou na edição de um "Manual para Planejamento de Embalagens", uma exposição didática, "Embalagem design e consumo" e um curso "planejamento de embalagens" dirigido para as empresas exportadoras.

O Ministério da Educação solicitou ao IDI uma pesquisa sobre o mobiliário escolar para todos os níveis de ensino com o objetivo de estabelecer critérios qualitativos em relação ao ensino moderno, de ergonomia, de fabricação e de controle da qualidade do mobiliário. Constatamos durante as nossas pesquisas, que os móveis escolares em oferta pelas indústrias não correspondiam aos critérios por nós elaborados e desenvolvemos junto com as indústrias novos modelos.

O projeto resultou na edição de cinco publicações orientando as indústrias, o corpo de professores e os órgãos públicos que especificavam e adquiriam mobiliário escolar. Desenvolvemos com apoio técnico da indústria modelos de acordo com as novas especificações.

Os dois projetos foram realizados num excelente clima de relacionamento com as entidades públicas, as induústrias acompanharam com entusiasmo nosso trabalho.

\section{nas instituições culturais}

O trabalho do designer é uma atividade essencialmente cultural. Eu desenvolvi, em 1967, para o Museu de Arte Moderna um sistema de exposições junto com um manual para planejamento de exposições. Implantei a metodologia em seguida e coordenei centenas de exposições de arte, sempre na postura de um designer, adaptando o espaço do museu e o sistema de exposições às mais diversas manifestações artísticas.

O IDI além das bienais de design planejou mostras didáticas, inclusive itinerantes, divulgando o design nas suas interrelações, dirigidas aos profissionais, aos empresários e ao público em geral.

Um evento especialmente interessante foi “Escritório, forma e função no século XX" (já citei antes em relação ao MEC), porque se tratava de uma empresa privada que adotou, na sua trajetória, uma política de design, visível na oferta dos seus produtos, na comunicação com o público através de impressos e da publicidade, em resumo, expressando em todos os detaIhes uma identidade coerente.

A empresa comemorou 25 anos de existência. Aliás, a ESDI tinha na época a mesma idade e não comemorou. A empresa resolveu marcar a data com um evento cultural numa forma especial. Não relatando coisas óbvias como sua origem, não falando do seu crescimento, das suas realizações, mas deixando em evidência seu conceito como empresa nacional, seu compromisso cultural e sua visão para os próximos 25 anos.

A exposição foi montada no Palácio Gustavo Capanema MEC, no Rio; no Museu da Casa Brasileia em São Paulo e no Palácio das Artes, em Belo Horizonte. A revista Design dedicou 10 páginas para esse evento. 
O retorno: a empresa subiu de "patamar" afirmou-se cada vez mais como uma empresa brasileira que investe em design, demonstrou sua solidez no mercado e isto através de um evento de caráter exclusivamente cultural.

A imprensa: a grande parceira nessa atividade cultural foi a imprensa. Jornalistas motivados por temas que nós levantamos, desenvolveram matérias que resultaramem páginas e páginas nos jornais e revistas. Foi a melhor resposta, a mais gratificante para a nossa atividade. Comentei muitos anos atrás: "Pode-se medir o sucesso de um evento pela metragem impressa nos jornais".

Fiz uma definição e exemplificação sucinta de cada área em que participei. 0 intuito é esclarecer as inter-relações indústria/ensino/pesquisa/cultura. A tentativa de realizar um trabalho integrado, considero esta a minha contribuição para nosso design.

Trabalhar em equipe faz parte da minha convicção profissional. Eu tive a sorte de no Brasil, no ensino, na pesquisa, na indústria e nas instituições culturais - ter sempre ótimos colaboradores e colegas em volta de mim. Por isso, a maioria dos resultados que eu tenho para apresentar é fruto de esforços coletivos. Receber o reconhecimento do governo e ainda do Ministério das Relações Exteriores, "o Ministério de Vanguarda", como eu o chamei uma vez, é uma grande honra. Mas, quero repetir: a maioria dos resultados que eu tenho para apresentar, é fruto de esforços coletivos. Eu gostaria que todos os meus colegas e colaboradores se sentissem neste momento comigo prestigiados!

O Ministério das Relações Exteriores comemorou no dia 14 de março de 2017 o Cinquentenário do Palácio Itamaraty e conferiu nessa ocasião a "Comenda da Ordem do Rio Branco" para várias pessoas e eu era uma delas. Infelizmente, por motivos de saúde eu não pude estar presente. Por sorte o prof. Joaquim Redig recebeu a condecoração em nome de seu pai, o arquiteto Olavo Redig de Campos e também em meu nome. Foi uma feliz coincidência. $\mathrm{O}$ arquiteto Olavo Redig de Campos, pai de Joaquim, é conhecido por importantes obras no Brasil e no Exterior e ocupou a chefía do serviço do patrimônio do Itamaraty durante trinta anos.

O professor Pedro Luiz Pereira de Souza encaminhou para o Itamaraty dados esclarecendo a relação do Instituto de Desenho Industrial do Museu de Arte Moderna com o Ministério das Relações Exteriores. O professor Freddy van Camp redigiu uma argumentação completa sobre a nossa atu- ação, nesse contexto, no Itamaraty e relatou a importância desse Ministério para a promoção e desenvolvimento de design no Brasil.

São três designers, professores, hoje com destaque no país, que me orgulho de dizer, foram meus alunos, alunos pioneiros, porque eles participaram logo no inicio de uma experiência que se chamava ESDI. Quero agradecer esses três amigos, de coração, pela dedicação ao velho companheiro.

\section{o que eu devo fazer ainda}

Primeiro escrever uma carta amável para o conslheiro Heitor Granafei, felicitando pelo sucesso do evento "Cinquentenário do Palácio Itamaraty", elogiando pela compreensão e sensibilidade nas questões de design e agradecendo pelo seu empenho junto ao Ministério de conceder a honrosa "Comenda da Ordem do Rio Branco".

Em segundo lugar, vou me aprofundar na história do Barão Rio Branco.

Em terceiro lugar, vou repetir aquele passeio memorável pela avenida Rio Branco, hoje um pouco menos apressado. Aliás dois anos atrás, a avenida se encontrava ainda nessa confusão por aquelas obras e eu atravessei a pista um pouco distraído e por um fio não fui atropelado por um ônibus, o motorista ainda me xingou. Depois daquele susto, nunca mais voltei para aquele lugar. Mas agora estou de novo em santa paz com a avenida Rio Branco. Vou seguir a dica da minha amiga Silvia Steinberg: Karl Heinz, vá até lá, ver como ficou a avenida Rio Branco agora. Vamos tomar um VLT. Boa ideia !

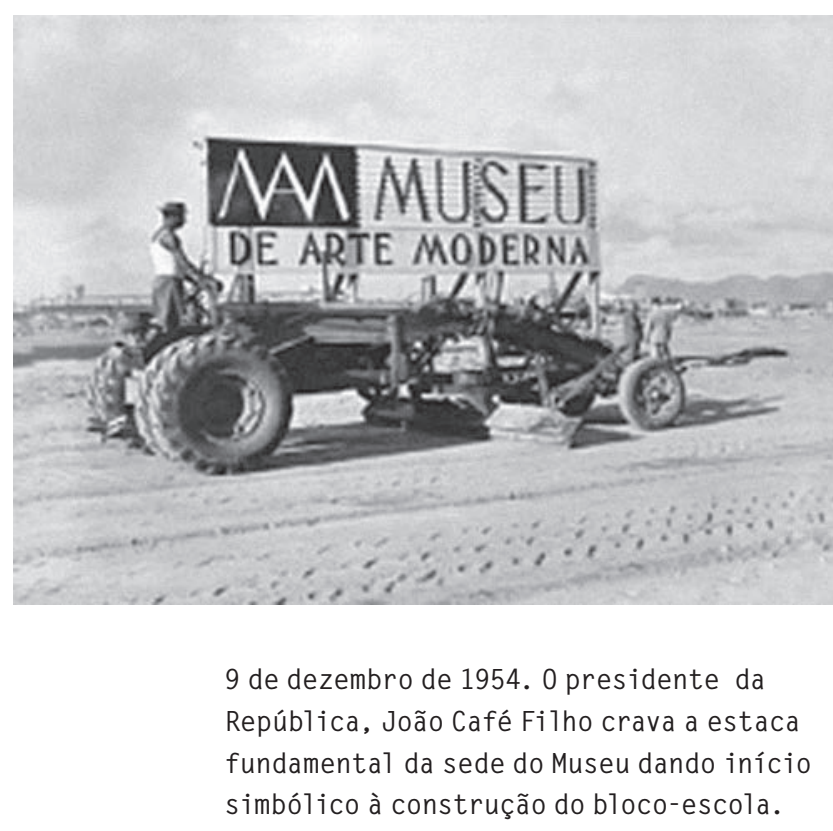




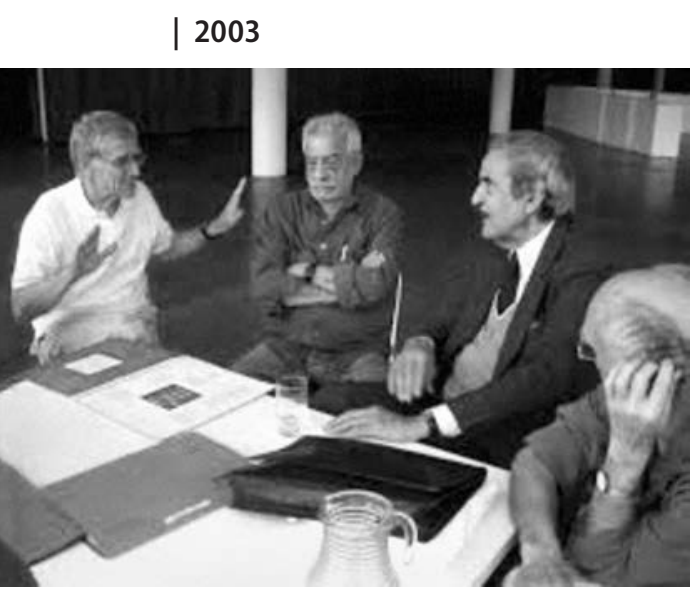

Bergmiller, Goebel, Maldonado e Pedro Luiz no MAM

Design Goebel Weyne Foto Rodolfo Capeto
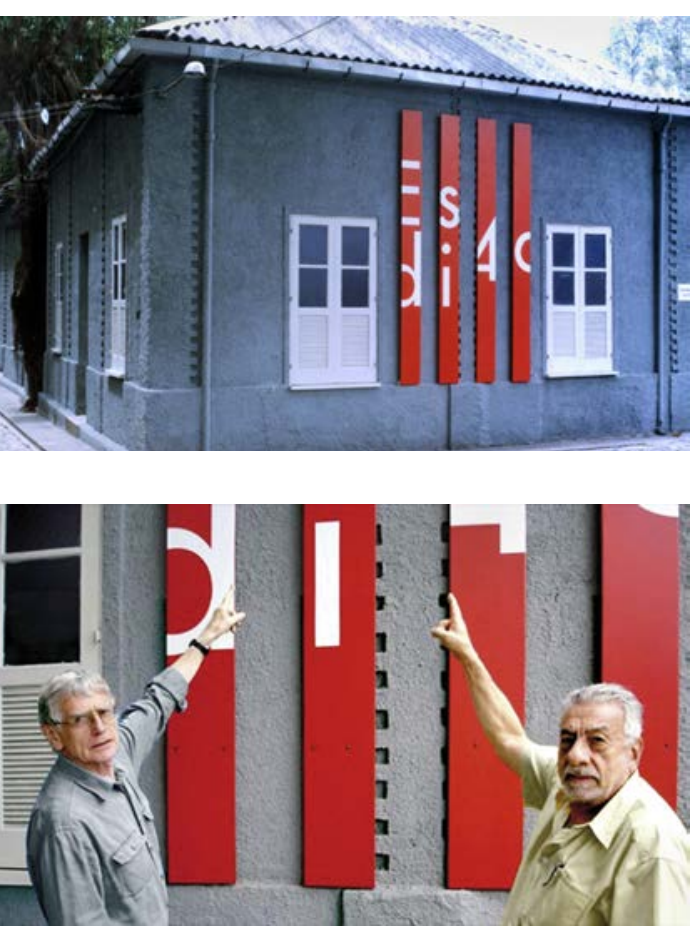

\section{parabéns para a ESDI pelos 40 anos}

Podem-se dizer perfeitamente 40 anos de design no Brasil porque uma profissão só existe num país quando existe também a preocupação de ensiná-la de forma sistemática. Essas árvores no terreno da ESDI, eu vi quando foram plantadas. Foi dias antes da inauguração da escola. E vejam como ficaram. Li uma vez que as árvores crescem três vezes mais rápido no nosso clima que nos países nórdicos

Também muitas coisas acontecem aqui mais aceleradas do que em outros lugares do mundo; às vezes falta uma análise mais profunda, às vezes as decisões não são suficientemente consistentes. Deve ser algo típico dos países em desenvolvimento, onde não há tempo a perder.

Neste cenário estou atuando, enfrentando desafios, até obrigado a improvisar, mas sem perder o controle, sempre tentando avaliar as consequências, porque enfim a responsabilidade vai cair em cima da gente. A espontaneidade é uma característica do Brasil, sempre me fascinou, entre outras razões, a resposta do porquê eu fiquei aqui.

Participei pela primeira vez numa reunião sobre a ESDI em janeiro de 1963. Estavam presentes o Wollner, Aloísio Magalhães, Maurício Roberto, diretor da escola, Flávio de Aquino, Flexa Ribeiro, secretário da Educação, e Simeão Leal, coordenador de assuntos culturais do Estado.

Nesse encontro foi apresentado o projeto ESDI elaborado com a assistência de "experts" americanos. Nessa altura já estava marcado o início das atividades escolares. Não me lembro mais de qual foi a minha reação ouvindo aquelas propostas ultrapassadas, mas Wollner e eu havíamos trazido uma visão bem diferente para uma escola de design contemporânea, sempre é bom lembrar, há 40 anos atrás. Mas o pessoal da reunião era um grupo de pessoas inteligentes e as nossas observações receberam de imediato todo o apoio e assim fomos solicitados a propor uma nova estruturação.

Saindo da reunião, o secretário da Educação me chamou de professor. Professor universitário na Alemanha goza do mais alto conceito social. No Brasil, ao longo dos anos, percebi que é um pouco diferente.

Wollner e eu nos tornamos professores, embora não tendo ainda uma experiência didática, mas estávamos praticando design já há alguns anos no Brasil, num campo que poderia ser chamado de virgem. Mas a gente tinha também a bagagem e a segurança trazidas da Escola de Ulm, a mais inovadora escola de design surgida depois da Bauhaus na Alemanha. Aliás, a HfG nem poderia ser chamada de uma escola tipicamente alemã; era uma instituição internacional, preocupada com o design em seu sentido mais amplo, chamado Umweltgestaltung. Professores e alunos chegaram de todos os lugares do mundo, curiosamente na- 
Bergmiller foi convidado por Gabriel Patrocínio, então diretor da Esdi, para fazer em 2002 a abertura dos trabalhos das festividades dos 40 anos da ESDI em 2003.

Freddy van Camp comenta 0 convite que antecede às comemorações. Interlocutores Goebel Weyne e Alexandre Wollner
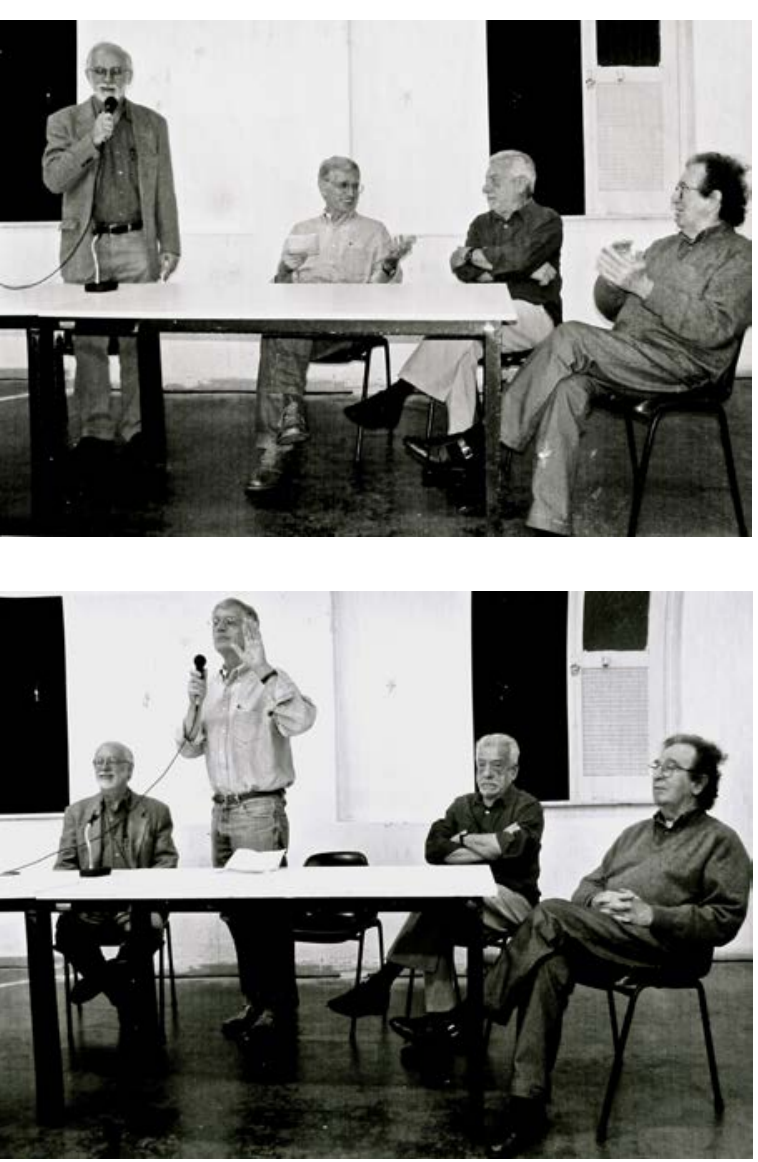

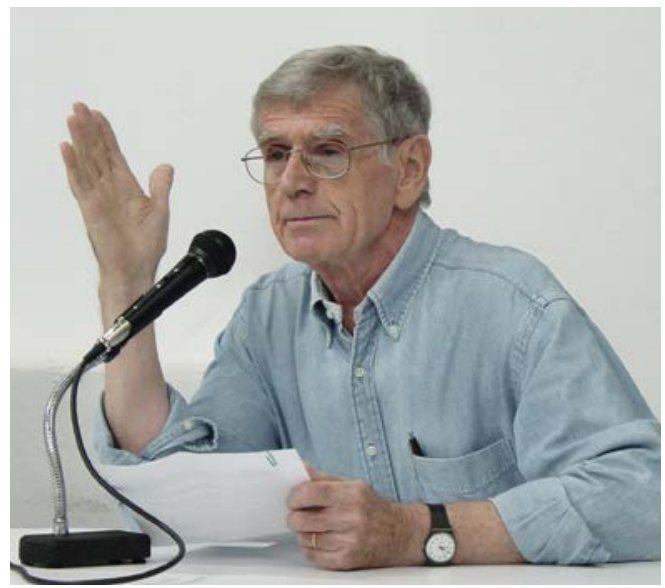

tural da cidade de Ulm havia apenas uma aluna, inclusive do Brasil que tinha nessa época cinco estudantes cursando a escola.

Acho que foi uma sorte para a ESDI que Wollner e eu estivéssemos aqui participando do projeto. Claro que foi sorte nossa também ter a oportunidade e a liberdade de discutir e propor ideias e concretizá-las. Mas, acima de tudo, foi sorte encontrar aquele entusiasmo tanto por parte dos alunos e dos colegas, como do governo. A imprensa também demonstrou sempre interesse e simpatia pela escola.

É lógico, portanto, que as raízes desta escola estejam na Escola de Ulm. Mas não foi um programa de Tomás Maldonado ou de Max Bill que chegou aqui e seus planos foram postos em prática. Foi muito mais a nossa experiência, de quatro anos estudando em Ulm e mais outros quatro anos no Brasil interpretando e adequando métodos e conceitos dentro de nossa realidade que deram consistência ao projeto. Para isso contribuiu também o fato de a maioria dos professores vir de campos e formações diferentes.

Experimentamos várias medidas inovadoras, inclusive diferentes de Ulm, e, logicamente, não faltaram críticas. Mas, seria péssimo se numa escola como esta, uma escola de design, tudo fosse aceito sem discussão. Acho que uma das coisas básicas que introduzimos foi motivar os alunos a justificar seus atos, sua produção, enfim, sua própria presença entre nós. Tudo isso foi válido também, para o professor. Conceitos não podem ser emitidos apenas sob seu foco limitado. Devese sempre considerar que o objetivo principal desta escola é formar designers responsáveis, profissionais que enxergam e sabem defender e solucionar problemas dentro de uma sociedade industrial.

Para qualquer profissional é muito saudável ensinar também. Aliás, eu aprendi muito com meus alunos, alunos que se tornaram colaboradores meus, colegas e amigos. Até hoje eu aprendo, não somente no âmbito escolar, mas também na indústria.

Não vou mais prolongar minhas considerações; estamos festejando 40 anos e existe um ditado popular na Alemanha, justamente da região de Ulm, que diz que o homem se torna esperto, toma jeito e toma juízo depois dos quarenta. Então, mais uma vez, felicidades ESDI e tome juízo.

Karl Heinz Bergmiller Rio de Janeiro, 2002 


\section{| 5 de dezembro de 1962}

Discurso de Carlos Lacerda, no Palácio da Guanabara, na assinatura do decreto de criação da ESDI.

Meus senhores, a rigor seria desnecessário pretendermos o que quer que seja à exposição, como sempre ilustre e oportuna que acaba de fazer o eminente Secretário de Educação do Estado. Cumpre porém assinalar que, com esse ato e com pouco mais, fizemos celebrar com modéstia a abertura do terceiro ano desta administração.

Faço, e por isso ouso aqui falar encerrando esta breve cerimônia, tendo em vista uma concepção que ouso exprimir porque creio traduz o sentimento profundo ainda que nem sempre explicado, da maior parte da nossa população

A principal crise brasileira, aquela que sobretudo dificulta a solução das outras, é a falta de quadros no País. A produção de homens capazes, o volume, se assim posso dizer, de homens em condições de influir na solução dos problemas, bastava a este país, quando ele era grande apenas na extensão territorial, mas não o era nem mesmo no vulto de sua população, e muito menos no número de pessoas em condições de consumir o que as suas elites podiam gerar, em arte, em riqueza, em técnica para problemas então relativamente simples.

Foi o tempo em que o Brasil tinha poucos engenheiros, mas a rigor não carecia de tê-los muitos. Tinha poucos músicos, poucos poetas, poucos marceneiros, poucos ferreiros, poucos jurisconsultos, poucos bastavam enfim para o que então eram as necessidades de consumo do povo brasileiro. Hoje felizmente, aumentou não somente a população, mas aumentou a sua exigência de civilização. No entanto a crise da Universidade, a crise da responsabilidade, a crise de uma autoridade verdadeiramente livre, consciente e capaz, fez com que empobrecesse enormemente a vida brasileira, e temos diante de nós o grave problema de formar uma democracia sem formar as elites populares, capazes realmente de dar-lhes significação, conteúdo e progresso autêntico.

No plano do nosso Estado, eu citaria como exemplo desse esforço de superação da carência de quadros, a criação do Hospital de Clínicas para a Universidade nascente do Estado, a fim de que os médicos possam sair da faculdade em condições de serem médicos, e não apenas com seu diploma debaixo do braço. Afim de que os médicos não proletarizem a medicina, transformando-a numa mera atividade profissional nos azares e acasos dos ambulatórios. 0 Instituto de Engenharia Sanitária que vem dar sentido a toda política de saneamento, a todo um esforço até aqui empírico, ainda que tecnicamente ajustado, de saneamento ou melhoria das condições sanitárias da vida em nosso Estado.

A função de pesquisa, a função de estabelecimento de normas, a luta contra a poluição das águas na baía de Guanabara e outras tarefas que se abrem ao Instituto de Engenharia Sanitária, criado nos quadros deste Estado, é outro desses esforços da criação de quadros para a formação daquelas elites sem as quais a democracia não pode se conduzir e cai necessariamente na desagregação e na desordem dos espíritos.

Este agora, depois de dois anos de lutas e de espera, graças à tenacidade e à lucidez de homens do valor do meu eminente amigo e companheiro de governo, professor Flexa Ribeiro, de homens dos quadros do Estado e me permito citar apenas um para resumir nele os demais, o professor Lamartine Oberg, e de homens da comunidade carioca, como aqueles que aqui hoje se encontram presentes, podemos lançar as bases da Escola Superior de Desenho Industrial, que visa, além de formar quadros para a utilização devida dos materiais e para a educação do gosto e do uso funcional de uma civilização industrial nascente, visa a uma alta tarefa, esta sim, profundamente nacionalista.

A de imprimir ao povo brasileiro, através dos produtos industriais que ele consome, uma forma que lhe seja própria, uma forma ao mesmo tempo funcional, de sentido estético profundo, pois a obra de arte sabe-o bem o homem moderno, não se mede apenas pelos quadros que ele prega na parede ou pelas esculturas que ele coloca nas praças, mas por tudo o que ele usa, desde a navalha de barba até a gravata que ele põe em torno do pescoço. Desde as formas das máquinas de escrever, como deu exemplo ao mundo, a função, a compreensão pioneira desse industrial que por assim dizer revolucionou a estética do desenho industrial, que é o grupo Olivetti, na Itália, ou o grupo Fiat na indústria automobilística.

Até essa compreensão de que podemos, como há pouco acentuava o Secretário de Educação, importar toda a vida "know-how" e técnica sem trazer a tudo isso uma contribuição que ouso esperar seja inovadora e surpreendente, como surpreendente e inovadora é sempre a contribuição da imaginação brasileira que lhe põem ao alcance uma forma de se educar e se exprimir. 
Ousamos certa vez, quando sonhávamos com esta Escola, figurá-la no plano da civilização industrial que nasce no Brasil, de importância comparável ao que foi a missão francesa para aqui trazida por D. João VI, na educação para a arte, na formação de uma arte brasileira.

Aqueles homens, como Grandjean de Montigny, como Debret, como tantos outros dos mais ilustres aos mais humildes serralheiros ou ferreiros que com eles vieram para o Brasil, formaram aqui o gosto e a técnica de que nasceram e que consumiram, durante todo o Império e larga parte da República, os nossos artistas e os nossos artífices desde então.

Pode-se mesmo dizer que a grande influência francesa no Brasil, a cultura francesa que modelou em tão larga medida a formação de uma cultura brasileira, deve-se por um lado ao comércio de moda e de livros, mas por outro lado e sobretudo, a vinda da missão francesa no começo do século passado.

Hoje esta escola, com os homens que para aqui irá trazer e com os homens que aqui irá formar, significa no liminar da imagem industrial do Brasil uma forma de dar melhores condições para que a admirável, espontânea e extraordinariamente fecundante capacidade da inteligência e da imaginação do trabalhador e do técnico brasileiro possa apropriar-se dessa técnica, para lançar, em uma expressão que em português não traduz perfeitamente tudo que ela significa, o desenho industrial, isto é, a forma e a utilização de vida dos materiais.

O sentido funcional dessa fabricação de materiais, e o sentido estético do uso desse material como elemento de civilização e de cultura de uma comunidade, tudo isso, esta Escola visa a ser, tudo isso, começa a ser, no momento em que a Guanabara, em ação pioneira, funda a primeira Escola Superior de Desenho Industrial da América Latina.

Eis porque entendi que não poderia haver momento mais alto, nem mais expressivo para marcar o início do $3^{\circ}$ ano de uma administração democrática e, nesse sentido, revolucionária na Guanabara,quando a de lançar hoje o marco da formação de uma Escola, que virá dar sentido e projeção duradoura ao esforço do trabalhador brasileiro, para aqui lançar as bases de uma civilização industrial e democrática.

Muito obrigado a todos.
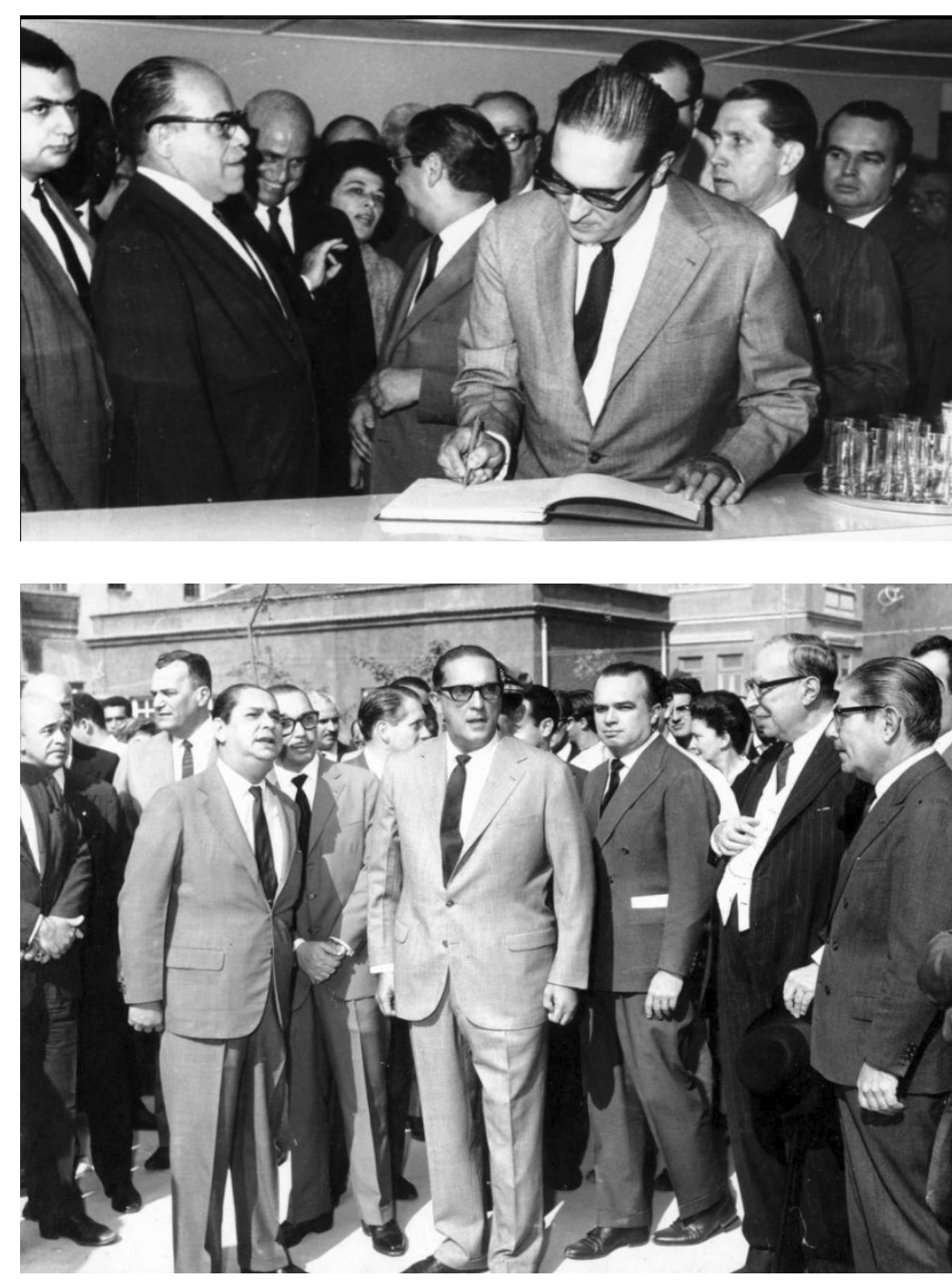

| 22 de dezembro de 1962

Carlos Lacerda assina a ata de fundação da ESDI no Palácio Guanabara.

| 10 de julho de 1963

O governador e sua equipe na inauguração da ESDI Em primeiro plano, da esquerda para a direita: Carlos Flexa Ribeiro, ${ }^{35}$ Secretário de Educação e Cultura do Estado da Guanabara, o radialista e vereador Raul Brunini, Carlos Lacerda, o arquiteto e primeiro diretor da ESDI, Maurício Roberto, Maurício Nabuco e Wladimir Alves de Sousa. 
| 12 de outubro de 1964

Construção do pavilhão de exposições.

Participam alunos, mestres e professores.

Vista interna no terreno da ESDI: uma aluna, o professor de sociologia, José Bonifácio Rodrigues e o diretor Flávio de Aquino observam o andamento da construção. 0 aluno matricula no 1 Roberto Verschleisser (de guarda-pó).

Na página ao lado fachada para a rua do Passeio no 80 em 1964 e 2017
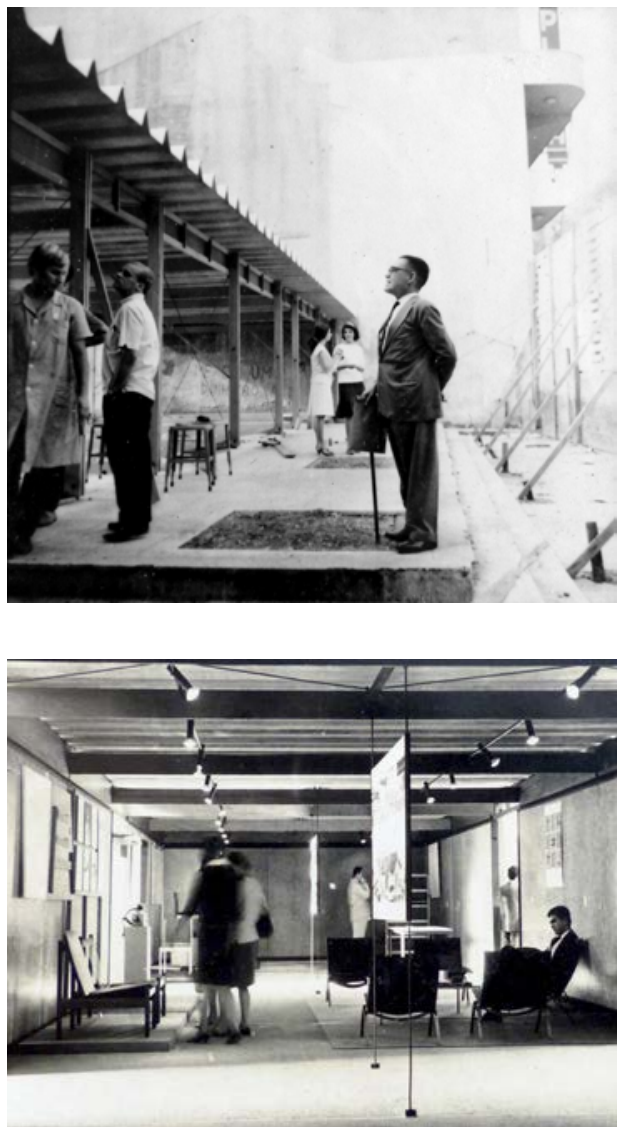

| 12 de fevereiro de 2017

Fechado há 16 anos o acesso à ESDI pela rua do Passeio no 80 foi reabaerto.


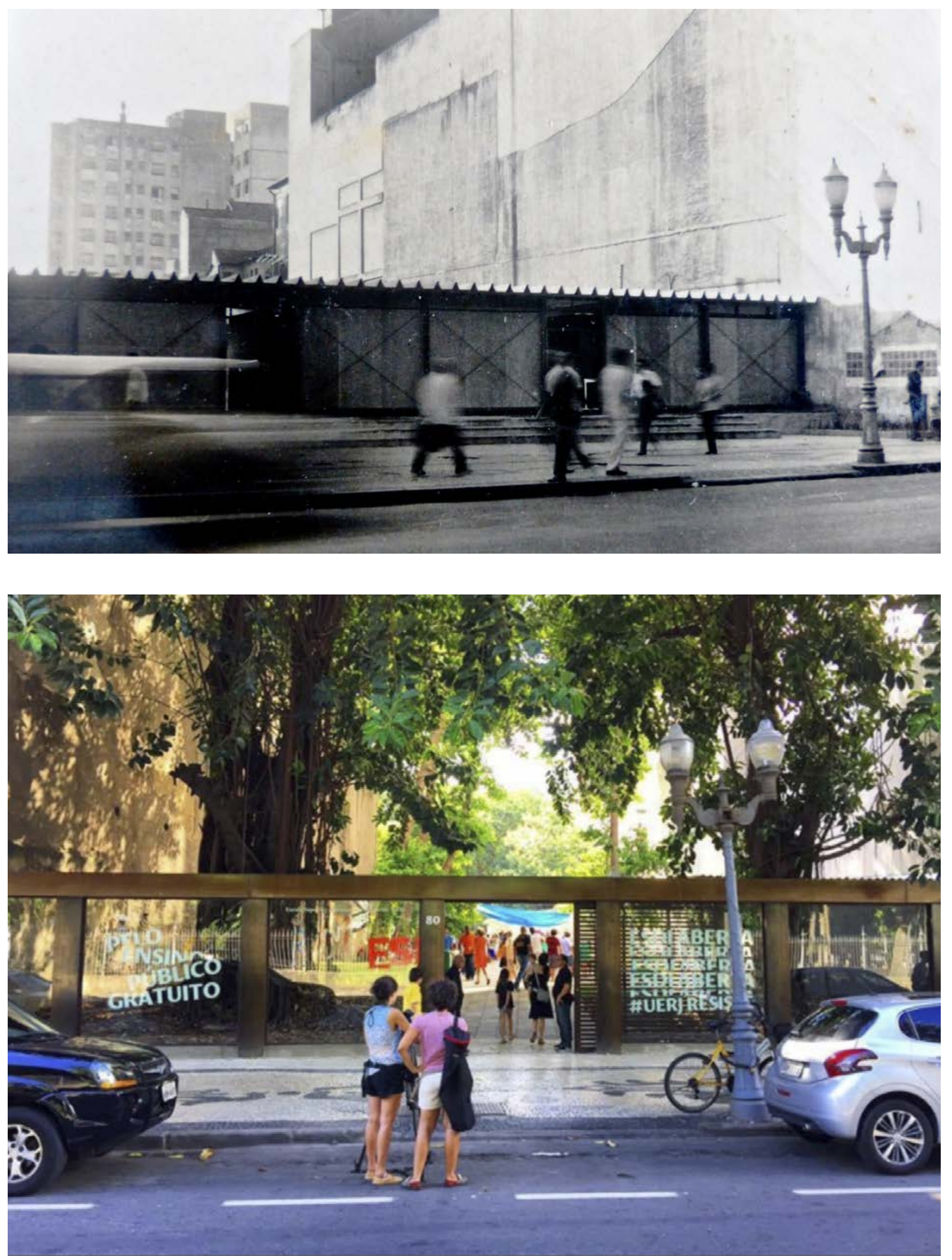

| 12 de outubro de $1964 \quad$ | 12 de fevereiro de 2017 


\section{notas | A ESDI e o ensino formal de design}

1. SIMONSEN, Roberto C. Evolução industrial do Brasil e outros estudos. Seleção, notas e bibliografia de Edgard Carone. São Paulo: EdUSP, 1973.

2. Ibid.

3. Juscelino Kubistchek e Carlos Lacerda. Dois dos principais políticos brasileiros das décadas de 1950-60, pertenciam a partidos políticos conservadores, porém divergentes em suas composições sociais, o Partido Social Democrático PSD e a União Democrática Nacional UDN, que, juntamente com um partido popular, o Partido Trabalhista Brasileiro PTB, dominaram a política nacional no período.

4. Jayme Maurício Rodrigues Siqueira (1927-1997). Crítico de arte com atuação importante no jornal carioca Correio da Manhã. Foi aluno do Liceu de Artes e Ofícios e estudou pintura com Alberto da Veiga Guignard. Iniciou sua carreira de jornalista no Correio da Manhã, em 1950, no qual escrevia sobre teatro, música, rádio, televisão, cinema e balé. Sua atuação no cenário cultural do Rio foi além da colaboração na imprensa: participou do movimento que buscava uma sede definitiva para o Museu de Arte Moderna MAM, criado em 1948. Nas novas instalações do MAM, Jayme Maurício passou a promover exposições de artistas como Manabu Mabe, Djanira e Hélio Oiticica.

5. Discurso do presidente Juscelino Kubitschek na inauguração do Museu de Arte Moderna do Rio de Janeiro, em 21 de janeiro de 1958.

6. Os grupos executivos foram artifícios administrativos criados pelo presidente Juscelino Kubitschek para evitar constrangimentos burocráticos às suas políticas desenvolvimentistas. Embora tais grupos legalmente não possuíssem poder decisório real, sua influência era suficiente para ditar os rumos nas políticas industrialistas preconizadas pelo grupo no poder, evitando, muitas vezes, problemas com licitações e outros de natureza semelhante.

7. O Parque do Flamengo (chamado pelos cariocas de 'Aterro') é um parque urbano inserido na paisagem da cidade do Rio de Janeiro entre o aeroporto Santos Dumont e a praia de Botafogo. O Parque, marginado de praias artificiais, resultou de sucessivos aterros da baía de Guanabara com terra proveniente do desmonte do Morro de Santo Antônio, no Centro, além de criar amplas vias expressas de tráfego é uma área pública destinada ao lazer da população do Rio de Janeiro. O Parque foi idealizado por Lota de Macedo Soares (Maria Carlota Costallat de Macedo Soares) e projetado a partir de 1961, sendo inaugurado simbolicamente em 1964, no Dia da Criança; foi reinaugurado oficialmente em 1965, pelo governo do Estado da Guanabara, como parte das comemorações do IV Centenário da Cidade. Ocupa uma área de um milhão e duzentos mil metros quadrados. Foi criado um Grupo de Trabalho para a Urbanização do Aterro (1961-1965) e a execução ficou a cargo da Sursan. Lota de Macedo Soares, presi- diu o Grupo de Trabalho chefiado pelo arquiteto e urbanista Affonso Eduardo Reidy, que projetou o MAM. Teve papel relevante no grupo o arquiteto-paisagista Roberto Burle Marx, na criação dos jardins e Richard Kelly na iluminação. Alexandre Wollner foi responsável pela programação visual. O Parque foi tombado pelo Instituto do Patrimônio Histórico e Artístico Nacional IPHAN, em 1965, e abriga o Museu de Arte Moderna do Rio de Janeiro, a Marina da Glória e o Parque Brigadeiro Eduardo Gomes. Em 1988 o conselheiro-relator do IPHAN, Gilberto Ferrez, firma um parecer enfatizando que "salvo as construções previstas, toda a área é non aedificandi". Esse ítem já constava do parecer original de tombamento em 1965. Em $1^{\circ}$ de junho de 2012, a UNESCO concede o título de Patrimônio Cultural da Humanidade à "paisagem urbana" da cidade do Rio de Janeiro sendo o Parque do Flamengo um dos sítios especificamente mencionados.

8. Júlio Roberto Katinsky (1932). Arquiteto e professor. Pósdoutor pela FAU-USP, onde foi professor entre 1962 e 2002. É autor de vários trabalhos acadêmicos, com destaque para Casas bandeiristas, (São Paulo: Instituto de Geografia da Universidade de São Paulo, 1976); Leituras de arquitetura, viagens, projetos (tese de livre-docência para a FAU/USP em 1979) ; Brasília em três tempos (São Paulo: Revan, 1991); Renascença: estudos periféricos (São Paulo: FAUUSP, 2002). Produziu ainda uma série de artigos publicados em periódicos, capítulos de livros, textos para jornais e trabalhos em anais de congressos, além de ter participado em bancas, comissões e eventos, e recebido prêmios e menções honrosas.

9. ZANINI, Walter (org.). Historia geral da arte no Brasil. Cap.11 Desenho Industrial. Júlio Katinsky. São Paulo: Instituto Walther Moreira Salles, 1983.

10. Maurício Roberto (1921-1996). Arquiteto. Formou-se pela Escola Nacional de Belas Artes em 1944. Em 1941, ainda estudante, começou a trabalhar no escritório fundado pelo seu irmão mais velho, Marcelo Roberto, que inicialmente se chamava M Roberto. Com a entrada de Milton Roberto, o irmão do meio, foi renomeado MM Roberto e, posteriormente, MMM Roberto com a entrada de Maurício. Com a morte de Marcelo em 1964, Maurício assumiu a direção do escritório, que continua existindo até hoje dirigido pelo seu filho, Marcio Roberto, com o nome de M Roberto. Foi presidente do Instituto de Arquitetos do Brasil (1956-1965) e diretor fundador da Escola Superior de Desenho Industrial do Rio de Janeiro (1963-1964).

11. Flávio de Aquino (1919 -1987). Arquiteto, crítico de arte e professor. Formou-se pela Faculdade Nacional de Arquitetura em 1945. Juntamente com Oscar Niemeyer, projetou a construção da Biblioteca Pública Estadual de Florianópolis. Como crítico literário e de arte, escreveu para o Jornal de Letras, o Diário de Notícias e para a revista Manchete. Autor de ensaios sobre pintores como Djanira, Pancetti e Portinari e de trabalhos analíticos mais gerais, como Três fases do movimento moderno, 1952. Participou do júri que escolheu o projeto urbanístico de Brasília, em que se destacou ao defender o trabalho vitorioso de Lúcio Costa. Lecionou Iniciação à Cultura Contemporânea na Escola Superior de Desenho Industrial, onde foi também 
diretor de 1964 a 1967. Foi professor de História da Arte e Estética na Faculdade de Arquitetura da Universidade Federal do Rio de Janeiro.

12. José Simeão Leal (1908-1996). Médico, administrador cultural, diplomata, crítico de arte, jornalista, colecionador, artista. Graduado em Medicina pela Universidade do Rio de Janeiro, em 1936. Entre 1947-1955 foi diretor do Serviço de Documentação do MEC, onde dirigiu e publicou as revistas Cultura, Arquivos, as coleções Cadernos de Cultura, Vidas Brasileiras, Letras e Artes, Teatro, entre outras publicações. Em 1950 começou a desenhar como hobby. Foi delegado do Brasil nas conferências da UNESCO (Paris/França e Índia, 1951-1960). Em 1962 é convidado por Carlos Lacerda a exercer a função de coordenador das atividades culturais da Secretaria de Educação e Cultura do Estado da Guanabara. Dirigiu a comissão de instalação da Escola Superior de Desenho Industrial. Foi diretor e fundador da Escola de Comunicação da UERJ (19711975) e diretor-secretário e coordenador cultural do Museu de Arte Moderna do Rio de Janeiro (1981-1982).

13. Joseph Carrero (1930). Estados Unidos. Designer e professor. Foi consultor convidado para participar da estruturação do projeto da ESDI, indicado por Jay Doblin, que não pôde atender ao convite em 1962.

14. Jay Doblin (1920 - 1989). Estados Unidos. Designer. Estudou Desenho Industrial no Pratt Institute, graduando-se em 1942, com um projeto em camuflagem tática militar. Logo depois de formado, foi contratado por Raymond Loewy, com quem trabalhou durante 12 anos, grande parte desse tempo como designer executivo das maiores contas do escritório que incluíam Shell Oil, Nabisco, Coca Cola, e BP. Doblin foi cofundador da Unimark International, que se tornou a maior empresa de design do mundo na época, com escritórios em sete países. Depois de deixar a Unimark em 1972, fundou a Jay Doblin \& Associates, em Chicago, uma empresa que desenvolveu programas inovadores para empresas como a Xerox Corporation, General Electric, American Hospital Association, Borg-Warner. Além de trabalhar em grandes escritórios, Doblin era também um educador influente. Atuou como presidente de uma divisão do Pratt Institute, dirigiu o Chicago-Institute of Design e parte do Illinois Institute of Technology IIT. Embora tenha mantido o caráter experimental da Escola, alterou seu currículo para incluir métodos mais estruturados e teorias de design. A ênfase em métodos de projeto continua sendo um dos pontos fortes da Escola. Sua influência também se estendeu no campo político. Em 1959, Doblin aconselhou o Ministério do Comércio Internacional e Indústria do Japão sobre a formação de uma política nacional de design que ajudou a desenvolver as leis de exportação, práticas de design e escolas que foram determinantes para a melhoria das qualidades dos produtos japoneses.

15. O International Council of Societies of Industrial Design ICSID é uma organização sem fins lucrativos fundada em 1957 que protege e promove os interesses da profissão de design industrial. Por meio de uma plataforma internacional que cria uma rede de estudantes e profissionais entre mais de 50 países, os usu- ários podem expressar seus pontos de vista e serem ouvidos. Juntos, associações profissionais, sociedades promocionais, instituições de ensino, órgãos governamentais e corporações criam um sistema funcional abrangente e diversificado.

16. Theodor Adorno (1903 -1969). Alemanha. Estudou filosofia, sociologia, psicologia e música na Universidade de Frankfurt e, aos 22 anos, foi para Viena, Áustria, onde aprendeu composição com Alban Berg. Ainda antes do final de sua graduação, conheceu dois de seus principais parceiros intelectuais - Max Horkheimer e Walter Benjamin. Entre 1921 e 1932, publicou cerca de cem artigos sobre crítica e estética musical. Sua carreira filosófica começa em 1933 com a publicação de sua tese Kierkegaard: a construção do estético. Em 1934, foi obrigado a emigrar para a Inglaterra devido à perseguição nazista aos judeus e durante três anos ensinou filosofia em Oxford. Em 1953, Adorno retorna ao Instituto de Pesquisa Sociais de Frankfurt, importante instituição para o renascimento intelectual da Alemanha após a Segunda Guerra Mundial, do qual foi um de seus grandes expoentes.

17. PAZ, Octavio. Convergências: ensaio sobre arte e literatura. Rio de Janeiro: Rocco, 1991.

18. Edmund Husserl (1859-1938). Alemanha. Matemático e filósofo. Estudou física, matemática, astronomia e filosofia nas Universidades de Leipzig, Berlim e Viena. Estabeleceu a escola da fenomenologia, que rompeu com a orientação positivista da ciência e filosofia de sua época, defendendo a experiência como fonte de todo o conhecimento. Aluno de Franz Brentano e Carl Stumpf, Husserl influenciou entre outros os alemães Edith Stein, Eugen Fink e Martin Heidegger, e os franceses Jean-Paul Sartre, Maurice Merleau-Ponty, Michel Henry e Jacques Derrida.

19. Henri Bergson (1859 -1941). França. Filósofo e diplomata. Um marco na filosofia moderna, ele exprime, no pensamento filosófico, um novo paradigma baseado na consciência, adquirida, segundo suas ideias, pelas conexões entre a vida orgânica e a vida social e psíquica, além da cultura particular a cada tempo e lugar. Bergson representa uma ruptura com toda a tradição cartesiana. Como diplomata, participa das discussões e negociações durante a Primeira Guerra Mundial e exerce influência sobre a decisão dos Estados Unidos em intervir no conflito. Em 1918, Bergson torna-se membro da Academia Francesa. Em 1927, recebe o Prêmio Nobel de literatura. Alguns de seus principais ensaios são: Matéria e memória de 1896, publicado originalmente em francês - Matière et Mémoire (Paris: Presses Universitaires de France, 1939); A Evolução criadora, 1907; e As Duas fontes da moral e da religião, 1932.

\section{MERLEAU-PONTY, Maurice. Sinais. Rio de Janeiro: Martins} Fontes, 1991.

21. Grande sertão, veredas é um livro escrito em 1956 por João Guimarães Rosa. Foi pensado pelo autor inicialmente como uma das novelas do livro Corpo de baile, lançado no mesmo ano. Porém, ganhou autonomia e acabou tornando-se um dos mais significativos livros da literatura brasileira. O romance 
gira em torno do jagunço Riobaldo, conhecido também por Tatarana ou Urutu-Branco, que é o narrador e protagonista do livro. Outro personagem é Diadorim com quem Riobaldo estabelece uma relação que se situa no limite entre a amizade e o relacionamento afetivo de um casal. Ao final, quando da morte de Diadorim, personagem vista até então como um jagunço de extrema valentia, mas também de grande sensibilidade, Riobaldo descobre que ele era, de fato, mulher. As frases e ditos de Riobaldo chegaram a ser interpretadas como mínimas obras literárias.

22. Daisy Igel (1928). Arquiteta, professora. Formada pelo Instituto de Design de Chicago, onde foi aluna de mestres como Buckminster Fuller, Konrad Wachsmann e Josef Albers. Foi professora da ESDI, substituindo Edgard Decurtins de 1965 a 1968 na disciplina de Metodologia Visual. Posteriormente, lecionou outra disciplina chamada Expressão em Duas e Três Dimensões, excluída dos currículos após as reformas de 1968-1970. Seu pai, Ernesto Igel, fundou a primeira empresa de distribuição de gás de cozinha no Brasil, em 1937 - A Empresa Brasileira de Gáz e Domicilio Ltda. Em 1938, o empreendimento foi renomeado dando origem à Ultragáz S.A.

23. O Banco Nacional da Habitação BNH, foi uma empresa pública brasileira voltada para o financiamento e produção de empreendimentos imobiliários. Foi a principal instituição federal de desenvolvimento urbano no Brasil e era gestora do FGTS e da formulação e implementação do Sistema Financeiro da Habitação SFH. Sua criação deu-se em agosto de 1964, através de projeto da deputada Sandra Cavalcanti, ligada a Carlos Lacerda. Sandra Cavalcanti foi depois nomeada a primeira presidente do $\mathrm{BNH}$.

24. A New Bauhaus foi sucessora da Bauhaus. Fundada em Chicago, em 1937, foi composta inicialmente por professores da antiga escola alemã, exilados nos Estados Unidos, sendo a primeira a ensinar desenho industrial no país. Antes de completar um ano, a New Bauhaus faliu e seu diretor fundador, László Moholy-Nagy, decidiu reabri-la com recursos próprios e de amigos, com o nome de The School of Design. Rapidamente os alunos desenvolveram uma grande quantidade de projetos, chegando a gerar 17 patentes em um único ano. Como reconhecimento, a Fundação Rockefeller e a Carnegie Corporation concederam-Ihe apoio econômico e a Escola é renomeada como Chicago Institute of Design. A fotografia desempenhou um papel mais relevante em Chicago do que havia exercido na Alemanha, com a direção de professores como György Kepes, Nathan Lerner, Arthur Siegel e Harry Callahan. O enfoque nas ciências naturais e humanas foi incrementado e a formação em técnicas mecânicas sofisticou-se. A partir de 1945, ela é incorporada ao Instituto de Tecnologia de Illinois ITI.

25. Johannes Itten (1888-1967). Suíça. Pintor, professor e escritor. Foi importante durante a primeira fase da Bauhaus, tendo influenciado na organização e estruturação do curso. Itten unia ideias místicas, religiosas e artísticas criando uma linguagem peculiar. Tinha uma ideia da natureza influenciada pelo Platonismo e por concepções orientais, sendo praticante de uma versão do Mazdaísmo, uma arcaica religião persa que exigia jejuns periódicos e uma dieta vegetariana. Na Bauhaus, ele instituiu o Vorkurs, um ensino preliminar no qual os alunos aprendiam de maneira inovadora, através de princípios e técnicas elementares, conceitos fundamentais de criação e de projeto. Suas aulas eram iniciadas com exercícios de ginástica e respiratórios. Em 1923, foi afastado da Escola por suas atitudes e princípios serem considerados de difícil assimilação nas proposições políticas e pedagógicas de Walter Gropius que conduziam a escola para uma colaboração mais concreta com a República de Weimar e, consequentemente, com seu desenvolvimento econômico e industrial. Em suas pesquisas pedagógicas desenvolveu o disco de cores, ainda hoje utilizado para a combinações harmoniosas de cores.

26. Paul Klee (1879-1940). Suíço naturalizado alemão. Pintor e poeta. Estudou na Academia de Belas Artes de Munique onde conheceu Kandinsky e Franz Marc, entre outros artistas de vanguarda. Em 1911, passou a fazer parte do grupo Der Blaue Reiter (O Cavaleiro Azul), que reunia artistas expressionistas liderados por Wassily Kandinsky. Durante a Primeira Guerra Mundial, Paul Klee integrou o exército da Alemanha. Foi professor da Bauhaus e da Academia de Düsseldorf. Com a ascensão dos nazistas ao poder, Klee retornou à Suíça. O seu estilo foi influenciado por diferentes tendências artísticas, incluindo o expressionismo, o cubismo e o surrealismo. Ele era um desenhista nato e por meio de extensivos experimentos, desenvolveu um total domínio da cor e da tonalidade. Suas ideias pedagógicas foram apresentadas em um dos livros editados pela Bauhaus o Pädagogisches Skizzenbuch.

27. "Seja marginal seja herói.": frase de Hélio Oiticica; "Não confie em ninguém com mais de trinta anos.": trecho de música "Com mais de 30", de Marcos Valle.

28. Carmen Portinho (1903-2001). Brasil. Engenheira e militante feminista. Em 1919, participou, com Bertha Lutz, da organização do movimento sufragista. Atuou na Federação Brasileira pelo Progresso Feminino desde sua fundação, chegando à vice-presidência. Na defesa do direito das mulheres ao voto, Carmen e outras companheiras chegaram a sobrevoar o Rio de Janeiro, na década de 1920, lançando panfletos em defesa do sufrágio feminino. Em 1937, ajudou a criar a Associação Brasileira de Engenheiras e Arquitetas ABEA e foi sua primeira presidente. Na ocasião, essa era a única entidade profissional de classe composta exclusivamente por mulheres. Em 1925, ainda no último ano do curso de engenharia, começou a dar aulas no Colégio Pedro II. O fato de uma mulher ministrar aulas em um internato masculino foi considerado um escândalo. O próprio ministro da Justiça quis interferir em sua nomeação para o colégio, mas não conseguiu tirá-la da cátedra. Em 1926, formou-se em engenharia civil na Escola Politécnica da Universidade do Brasil, sendo a terceira mulher a se formar engenheira no país. Participou ativamente da construção do Museu de Arte Moderna do Rio de Janeiro MAM/RJ e, posteriormente, dirigiu a Escola Superior de Desenho Industrial ESDI de 1967 a 1988.

29. A primeira exposição internacional de desenho industrial realizada no Brasil foi organizada em 1968, por professores da Escola Superior de Desenho Industrial ESDI. Denominada 
Desenho Industrial 68 - Bienal Internacional do Rio de Janeiro, a mostra foi dedicada tanto ao desenho de produto quanto à comunicação visual, com representação da produção nacional e internacional. Com curadoria geral dos designers Karl Heinz Bergmiller e Goebel Weyne, a mostra nacional teve a participação da ESDI e da Faculdade de Arquitetura e Urbanismo da Universidade de São Paulo FAU/USP. A mostra estrangeira teve como curadores associados Arthur Lício Pontual e Norman Westwater, que selecionaram trabalhos dos Estados Unidos, Grã-Bretanha e Canadá. Seis instituições patrocinaram o evento: Ministério das Relações Exteriores, Museu de Arte Moderna, Escola Superior de Desenho Industrial, Associação Brasileira de Desenho Industrial, Fundação Bienal de São Paulo e Confederação Nacional da Indústria.

30. O Movimento Tenentista teve início na década de 1920, no contexto do pós-Primeira Guerra Mundial, em que a questão da defesa nacional e de outras ideias nacionalistas ganhou evidência. Os oficiais brasileiros se ressentiam de políticas mais efetivas sobre tais questões e mostravam-se descontentes com a nomeação do civil Pandiá Calógeras para o Ministério da Guerra, pelo presidente Epitácio Pessoa. Foi nesse quadro de crescente insatisfação, com as condições do Exército e com a política do governo, que eclodiram diversos levantes militares. Os principais movimentos tenentistas da década de 1920 foram os 18 do Forte, os levantes de 1924, e a Coluna Prestes. As propostas políticas dos tenentes de uma maneira geral se vinculavam ao clima do pós-Primeira Guerra Mundial, marcado pelo avanço do nacionalismo e da centralização política. Entre meados da década de 1920 e o início dos anos 1930, foi tomando corpo a proposta de uma intervenção militar. Em 1930, a vitória do candidato oficial Júlio Prestes contra o oposicionista Getúlio Vargas promoveu divisões nos grupos regionais dominantes. A conspiração se fortaleceu no decorrer daquele ano, contando com o apoio de lideranças civis e militares. Os tenentes, mesmo divididos, tiveram um papel fundamental tanto na preparação como na direção do movimento que promoveu a derrubada do governo na Revolução de 1930.

31. "Cuidando da criação", texto avulso, de Roberto Amaro Lanari distribuído na ESDI durante as mobilizações de 1968-1970.

32. José Bonifácio Martins Rodrigues foi professor de Antropologia Cultural na ESDI, disciplina prevista no currículo que vigorou até 1968. Foi aluno e professor da Universidade do Distrito Federal, autoritariamente incorporada à Universidade do Brasil, atual UFRJ, pelo todo-poderoso ministro da Educação do Estado Novo varguista, Gustavo Capanema. O “Club de Sociologia", fundado em 1937, com a participação de Gilberto Freyre - de quem Bonifácio era muito próximo - foi praticamente dissolvido. Esse club, segundo a pesquisadora Simone Meucci, em sua tese de doutorado, na Unicamp, em 2006, “Gilberto Freyre e a Sociologia no Brasil: da sistematização à constituição do campo científico", foi uma agremiação intelectual organizada por Gilberto Freyre e José Bonifácio que buscava discutir ideias acerca da sociologia e da cultura brasileira, e se manteve ativa mesmo depois do fechamento da UDF. A presença de Bonifácio na ESDI, por variadas razões, entre elas o radicalismo politico da época, não foi devidamente aproveitada. Em 1969 ele deixou a escola.
33. "O que o desenho industrial pode fazer pelo país". Texto distribuído na ESDI por ocasião da aula inaugural ministrada por Aloísio Magalhães em 1978.

34. O Risorgimento foi um movimento político ocorrido na Itália. Não foi uma simples rebelião burguesa e nem uma mobilização ocorrida na segunda metade do século XIX, como pode sugerir a Guerra de Unificação que durou de 1865 até 1870. Pode-se considerar que esse movimento buscou a unificação do país desde 1815. A Itália era então um conjunto de pequenos Estados dependentes e submetidos a potências estrangeiras, particularmente ao Império Austro-Húngaro. Em grande parte as ideias oriundas da Revolução Francesa e a presença francesa através das tropas de Napoleão, exerceram uma forte influência no desenvolvimento de reformas liberais e na extinção de privilégios feudais e eclesiásticos. Depois da queda de Napoleão em 1814 e após o Congresso de Viena em 1815 a Itália foi outra vez subdividida e submetida ao absolutismo e aos sistemas monárquicos tradicionais. O Reino da Sardenha foi o único a não se submeter a esse processo e lá se originou a mobilização política que culminaria em 1870 com a unificação do país. As ideias revolucionárias e nacionalistas propagaram-se incentivadas pelo progresso econômico, principalmente da indústria têxtil do Reino da Sardenha que necessitava de um mercado mais amplo. As ferrovias desempenharam então um importante papel técnico nesse aspecto. Mas, a exemplo do que ocorreu também na Alemanha, além dos aspectos econômicos havia uma mobilização cultural importante a favor da unificação. Apesar de estarem separados por fronteiras artificiais e por reis estrangeiros impostos pelos grandes impérios, o idioma permanecia como forte elemento de unificação de todo o país: Dante, Petrarca, Bocaccio e tantos outros eram autores apreciados por todos os italianos. Além disso, o Romantismo acrescentou a toda essa mobilização um forte elemento de propaganda e agitação em todas as manifestações artísticas além da literatura. Muitas das obras então criadas eram plenas de alusões à tirania e à escravidão, destacando-se as óperas de Giuseppe Verdi (1813-1901), cujo próprio nome era usado como slogan político grafitado nos muros das cidades italianas: VERDI - Vittorio Emanuele Re D'Italia. A fase final da mobilização política foi precisamente encabeçada por Vittorio Emanuele II, rei do Piemonte e príncipe da Sardenha, que foi apoiado pelos conservadores liberais, sobrepondo-se aos republicanos e revolucionários como Giuseppe Mazzini e Giuseppe Garibaldi.

35. Carlos Flexa Ribeiro (1914-1991). Bacharel em direito e história pela Universidade do Distrito Federal. Em 1947 participou da fundação do Partido Socialista Brasileiro. A partir de 1951, foi professor no Instituto Municipal de Belas Artes IBA. Em 1955, tornou-se diretor-geral do Museu de Arte Moderna do Rio de Janeiro MAM/RJ. Em 1961, foi nomeado pelo governador Carlos Lacerda secretário da Educação e Cultura do Estado da Guanabara, função que exerceu até 1965 . Em novembro de 1966, elegeu-se deputado federal na legenda da Arena. Diretor-geral do Departamento de Educação da Comissão das Nações Unidas para a Educação, a Ciência e a Cultura (Unesco), em Paris, de 1967 a 1970, reelegeu-se deputado federal em 1970 e 1974, desta vez pelo novo estado do Rio de Janeiro. Em 1978, foi eleito diretor-executivo do MAM do Rio de Janeiro e em 1982 tornou-se vice-presidente da instituição. 